COLUMBLA LIBRARIES OFFSITE

ERGEY.

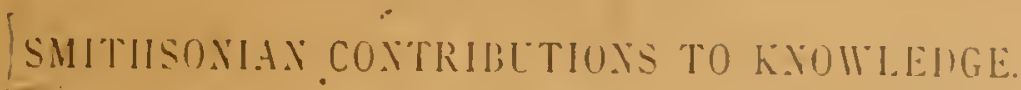

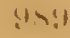

\title{
Ibodghills ffult.
}

T.IHE

COMPUSITION OF EXPIREI) AIR

AXn ITS

EFIICTS LPON ANIIAL, LITE.

11

J. S. BILI.INGS, M.D., S. WEIR MITCHELL, M.I).

AND D. H. BERGEV, II.D.

CITY GF WAMHATOS

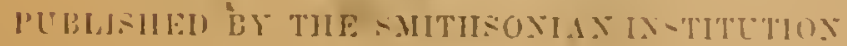

1895. 


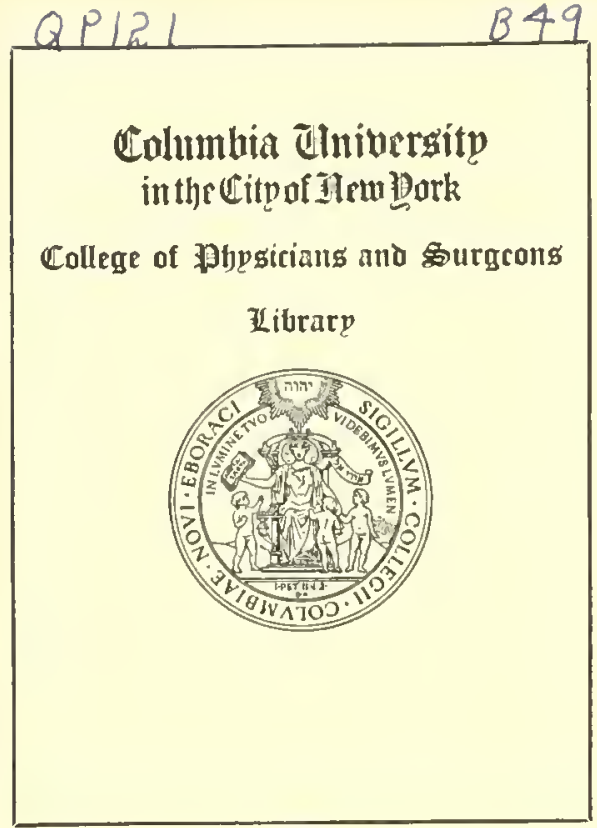


Digitized by the Internet Archive in 2010 with funding from Columbia University Libraries 

SMITHSONIAN CONTRIBUTIONS TO KNOWLEDGE. 989

\section{IIboogkins jfullo.}

THE

Composition OF EXPIRED AIR

AND ITS

EFFECTS UPON ANIMAL LIIE.

BI

J. S. BILLINGS, M.D., S. WEIR MITCHELL, M.D.

AND D. H. BERGEY, M.D.

CITY OF WASIINGTON :

P'UBHALIED BY THE SWTHSONIAN INSTITUTION.

1895. 
COMMISSION TO WHOM THIS MEMOIR

HAS DEFN REFERRED.

HORATIO C. WOOD.

WILLIAM HENRY WELCH.

CH.IRLES SEDGWICK MINOT. 


\section{ADVERTISEMENT.}

The present menoil is the result ol a series of inventigntions male

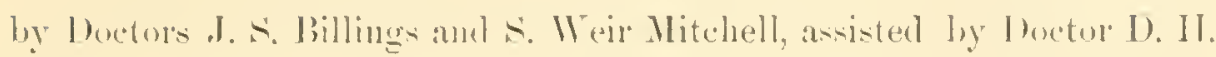

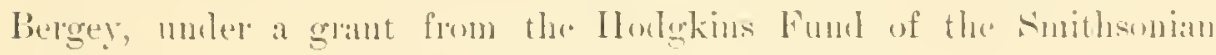
Institution, for the purpose of determining the nature of the peculian substances of organic origin contained in the ail expired ly hunan beings, with special reference to the pratical application of the results abtained to problems of rentilation for inhabited rooms.

In areorlance with the rule arlopted by the smithsonian Institution the work hak been submitted to a emmmittee, in the present instance cons

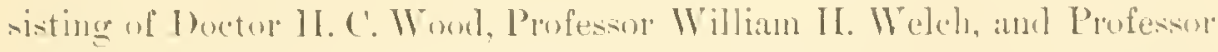
Charles s. Minot, and having been recommented by them for publication, it is herewith presented in the series of Contributions to Kinowlerlge.

S. P. LANGLEY,

SECIRLATIY.

Wasmatox, November, 1895. 



\section{Tine Composition of Expired Air, and its Effects upon Animal Life.}

REPURT ON THE RESLLTS OF AX IXYESTIRTIOY MADE FOR TIE SMTIISONIN INSTITUTUS LYHR THE PROYISIONS OH THE HOMGKNS FUNI,

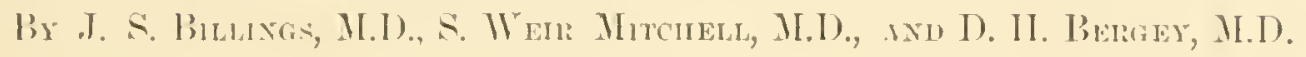

In May, 1 s!a, a grant was made from the Hodgkins Fund to Ins. Joln s. Billings and $\mathrm{s}$. Weir Mitchell, "for the purpose of conducting an investigation into the nature of the peculiar sulsatances of organic orign contained in the arrexpired by human beings, with spedial reference to the practical application of the results ohtamed to problens of rentilation for inhahited rooms."

For a number of rear prior to 1858 the prevaiting view anong plysicians and sanitarians had been that the discomfort and dangers to health and life which hat been known to exist, sometimes at least, in mrentilated rooms ocenpied by a number of human beings, were langely or entirely due to peeuliar organie matters containcel in the air expired by these persms, and that the increase in carbonie acid due to respuration had but little effect in producing these results, its chief imprort. ance being that it fumishel a convenient means of detemining the amount of vitiation of the air. Recently, howerer, several experimenters have conduded that the oreanic matters in the exhaled heath are not harmful, at all events to animals, and the main ohject of the proposed investigation was to determine the correctness of these eonchusions. For this purpose a scheme of experimentation was prepared by hr. Billings and Mitchell, which scheme has been carried out in the Labouatory of Ilyrene of the Unirersity of Penniyrania, by Dr. D. H. Bergey, assisted at times in the chemical work by 1)r. Uill S. Warwick, and in some of the patholocrical investigations hy Dr. Ingersoll Olmsted, and under the general supervision of Dr. 1. C. Abhott. First $\Lambda$ sisistunt in the Laboratory, to whom thanks are due formany valuable suggestions during the progress of the work. From time to time Dr. 
Bergey's notes on the result of his experiments have been submitted to lors. Billinge and Mlitehell, who have suggented modifications or new experiments as the

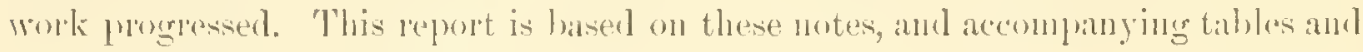
(bants, griven in the Appendix.

The eft'octs probluced on animals and men by an atmesphere contaminated with thedir exhalations, and with particulate matters derived from their bodies or thear immediate surroundings, may be divided into atente and chronic. The aroute eftect may be death in a few minutes or homrs, as shown by the results observal in the lialck 1Lole of ('alcutta, in the steamer Condonder"! and in many of the experiments referred to in this report, or it may be simply great disconfort, especially in those unacenstomed to such comditions.

The ehronic effects inclucle the farvoring of the action of certain specitic canses of lisease commonly known as contagions, if these are present, and perhaph also a general lowering of vitality.

The statistical evidence collected by the English burrack and llospital Commission (1) * as to the effects of insufficient ventilation upon the health of soldiers

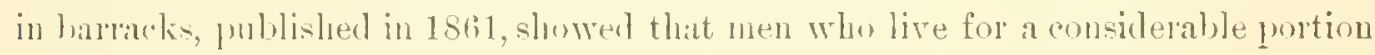
of theil time in badly ventilated roms lave higher sickness and death-lates thin have those who occupy well sentilated rooms, other conditions being the same; and this has also been found to be true with regard to monkeys and other animals. It is evilent, lowerer, that in a rom eccupied hy animals or men there are many somrees of impmrity besinles the exhalerl breath, and it is still a ruestion whether the explired air contains substances injurions to life, excluding carbonic acid.

'The widely divergent results obtained and conclusions reached by different invastigators during the list ten years as to whether the exhaled breath of men and animals contains a peculiar rolatile organic poison, have made it desirable to repeat and vary such experiments in order, if possible, to settle this important point. 'The chemical analyses of the air of overerowled roms, and the experiments upon animals witl valions proportions of carbonic acid, made by many incestigators, indicate that the evil effects observel are probably not due to the comparatively small proportions of carbonic acid usually found under such circumstances.

It was shown by Lellane (2), in $1842-43$, that an animal can breathe an atmosphere containing as much as 30 per cent. of carbonic acid for three-quarters of an hom, provided that the percentage of oxygen was 70, and then quickly recover. from the depression induced by this mixture after removal to the normal atmosphere. He also demonstrated that under the conditions in which the quantity of

* The numbers in parentheses refer to the bibliographical list appended to this report. 
carlunic aciet rises pereeptibly in theatres, ete., the reshetion of oxgen is quite insigniticant, and that the proportion ranely falls behow on pere cent.

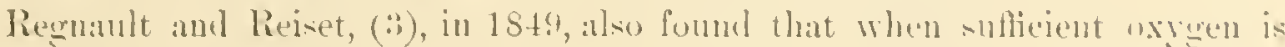
supplied to an atmesphere quite rich in earbonic acil, an animal ean still live in it. Friecllamber and II erter (t) fonml that the breathing of an atmosphere coutaining

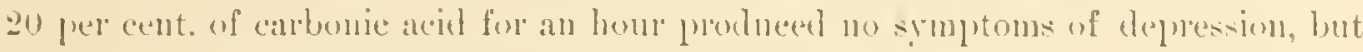
cansed stimulation of the respiratory centres and an incerasen aretivity of the he:ald.

Claude Bernard (5), in $185 \%$, experimented with animals confued in atmos.

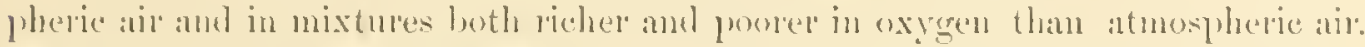

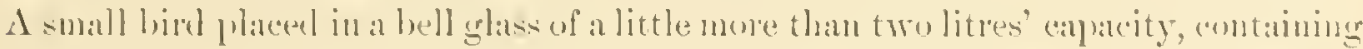

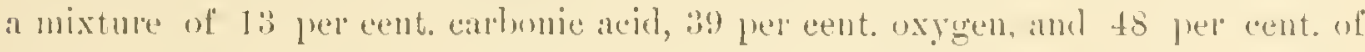
nitrogen, died in two and one-half homrs. He demonstrated that earbonic ach is not prisonoms when injected muler the skin of animali-ats mude ats one litre injecterl muler the skin of a ribbit producing no ill effects. No ill effects followed the injection of the gas inter the jugulal vein and into the cantid artery. An

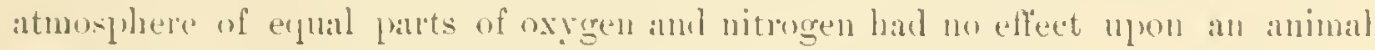
comfined in it, while an atmosplice eomposed of equal parts of carbonice acil and

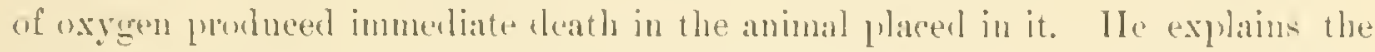
poismons afferets of carbonic: acid when respired to be lus to the fact that it deprives the animal of oxygen. Similar results were reported by Valentin (i) and by P'aul Bert (i).

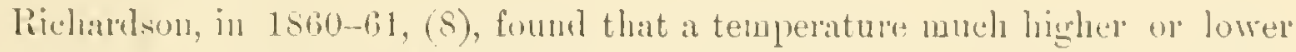
than $\geq 0^{\circ} \mathrm{C}$. had the effect of shortening very considerably the lives of animals confincd in an unrentilated jan, and that these effects were more markerl when the amimals were confined in an atmosplore richer in oxygen than air, in which cose le fouml that by passing electrie sparks from a frietional machine through the fatal air (haring frevinusly deprived it of its earbonie aciel) it was again male cilpable of supporting life, from which he concheled that the oxygen is "devital. ized" churug respiration, and that the electric spark has the faculty of revitulizing it.

Yon Pettenkofer, in 1S60-69, (9), showed that the symptoms observed in

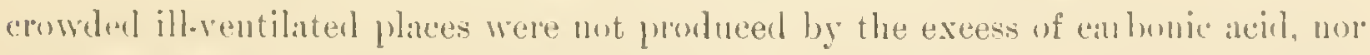
by a decerease in the proprotion of axygen in the air; neither of these being sullicient in ond dwellings, theatres, ete., to produce toxic effrets. He lial not belicre

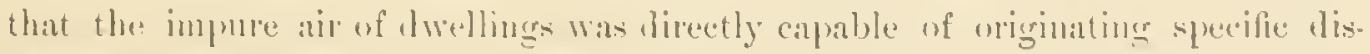
eases, or that it was really a poison in the orelinary sense of the term, but that it diminished the capalsility of withstanding the influences of diseise-prodncing agen. 
cies on the part of those continually hreathing such ail, and lair down the rule, which has been atcented and tanght by sanitarians for thirty-five years, that the proportion of carbonic acid in the atmosplete of inlathited places affords a safe indication as to the anount of the ofher impurities resulting from respiration and other exhalations from the bolies of the acenpants.

Ifammond, in $1563,(10)$, reported experiments in which he songht to remore the carbonic: acid and moisture, and to supply fresh air as fist as it is needed to take the place of the carbonic acid lemoverl, thus leaving the "organic matter" to accummlate in the vessel. For this purpose lie confined a monse in a large jar, in which were several sponges saturated with barytar-water, by which the carbonic acid was removed at fast as formed. Fresh ab was suplied as fast as required by means of a tube communicating with the bell jar and elosed by water in the bend of the tube, which acted as a valve. As the air in the bell glass was rarefied by respiration and absorption of the corbonic achl, fresh air flowerl in from withont, while the armangenent of the tube prevented the air of the bell glass from passing out. The watery rapor exhaled by the animal was absorbed by two or three small pieces of chloride of calcimm. The mouse thed in forty minutes. The observation was repeated many times, and death ensued invarialy in less than an hour. On cansing the ritiated air to pass through a solution of permanganate of potash the presence of organic matters in large quantity was demonstrated.

Ransome, in $1870,(11)$, reported a series of very interesting investigations upon "Organic Matter of Human Breath in Health and Disease." By conleusing the aqueous rapor of the human breath and analyzing it by the Nauklyn and Chapman method, he found that "in ordinary respiration abont $0.2 \mathrm{~g}$. of organic matter is given off from a bealthy man's lungs in 24 hours," while in the air expired by persons affected with certain diseases, he found great varations in the amount of organic matter, the amount being greatest in a case of phthisis complicated with Bright's disease.

Smith (12) employed a lead chamber in his investigations npon the question whether human lungs give off any poisonous agent other than carbonic acid. He found the pulse to fall from 73 to 57 beats per minute, and the number of respinations to lise from 15.5 to 24 , as the carbonic acid in the atmosphere increased from .0. to 1.73 per cent. during four hours. Th hen the proportion of carbonic acid rose to 3 per cent. there appeared great weakness of the cinculation with slowing of the leart's action, and great dificulty in respiration. IJe believed that these results should be attributed to other conditions rather than to the excess of carbonic acid, because he foum later that it was ouly when lamps became dim in an atmosphere 
-indicating a propertion of abont 10 per cent. of carbonie acil present-that the lecipiration berame. ditlicult.

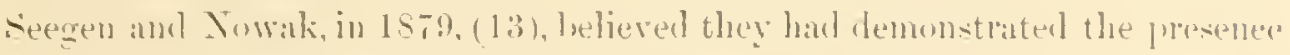
of poisonoms organic mattel in the explued hreatle, lut the quantity foumd wats so small that they faileal to determine its cxinet natme and properties.

Hermans, in $1 \leq 83,(1+)$, was mable to detect any organic matter in the atmosfhere of a tin cage in which sereral persons hat lueen contined for a number of

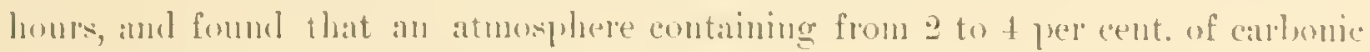
acel and 15 per cent. of oxygen was not toxic.

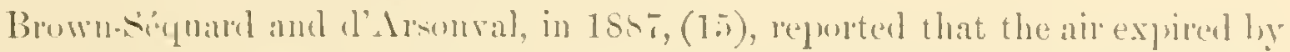
men and dere in a state of health has the power of producing toxice phemomena: citing three series of "xperiments on mblits wheresuch phenomenal were observer. In the first series they injected into the vancular system of a rablit 4 to 6 c. c. of fluid obtained ly injecting from 15 to 25 c. c. of pure filtered watep into the

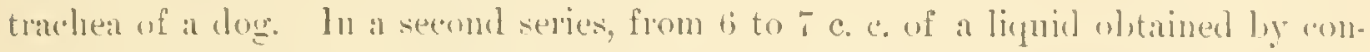
densing the moisture in the exhaled hreath of a mam, were injected into the andia, or into a rein, of a rabhit. In the third series from tob c. ce of a liynde obtamed by comdemsing the moistme in the exhaled breath of a trabeotomized doge were used. The andensed liguid thus obtained was filtered and then injerted rither into the jugnlar rein or the carotid arters.

The symptoms olserved were dilatation of the pupils and increase of the heartbeat to 240,280, or eren :300 jer minute, lasting for sereral days or aren weeks. The temperature lemaned nomal; the respiratory morements were generally stowed; and usually there was obsemed paralysis of the posterion members Choleraic diarrhea was invariably present. Ieath usually took flate in al few

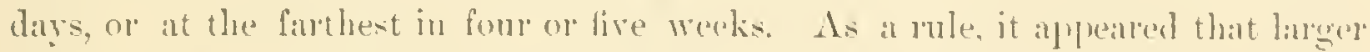
doses cansed laboned respiration, violent retchime, and contracted pupils. A rapul lowering of temperatmre, $19.5^{\circ}$ to $5.0^{\circ}$ C., was sometimes ubserved. The appen rancer that presented just mortem were much like those observed in cardiac sincope.

They believed they hat diseorered a rolatile organd poison in the eshalded breath and the moristure combensed from it. This poison they helieved to be of the natme of an organic alkaloid, on a ptomane not milike briegrer's ptomaine (16).

In further reports, in 18Ss, (17), they state that none of eleven lablits in which the condensed pulmonary vipor had been injected into the varculan system

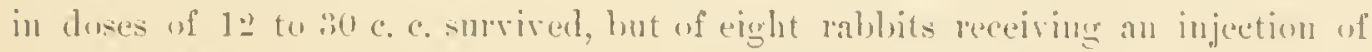
from t to o e. e., three were living after the lapse of from four to five weeks, but were then weak. When the flud was injected wnder the skin of the thoras and 
in the axillat, five out of seven rabbits lier rapilly. The lesults were nuch the sime as when it was injorted into the blom. Ther quantity of the condensed liguid

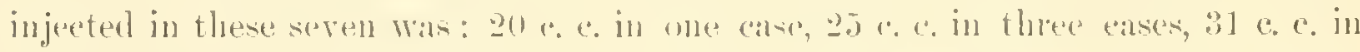

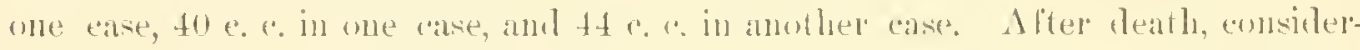

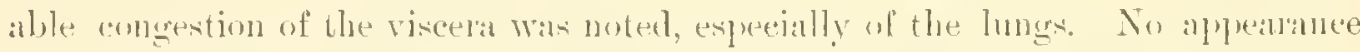

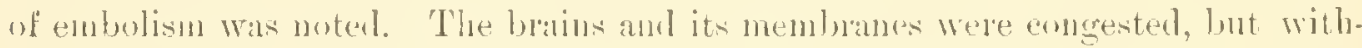
ont visible lesion. The andensed linuid turns eoncentrated sulphurie acial yellow.

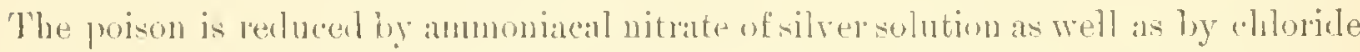
of golk. Afterlubiling in a close ressel it is still toxie, shoving that the poison is

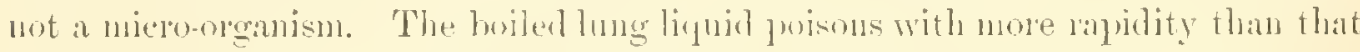
which has not been sterilized, and naty kill a pigeon and a guineapig as well as a rablut; it may kill by being injeeted into the reetum or into the stomach; a gunea-prig two months ohl was killed within twelve hours hy an injection of 3 e. e. into the peritoneal carity. If injected into the lungs this ligniri produces rapial congestion followed hy true inflammation and red hejatization.

In an experinent with two dogs it was arranged that one breatled ordinary ail and the second inhaled all which eame foum the lungs of the other. The Angs were of the same weight, 15 kilograms. The experinent continued for six hours and forty minutes. No applecialle or immediate consecutire aceidents were protuced.

In a second experment the pulmonary liquin was eollected from togs through a tracheotomy tube to exchule impurities funisher by the month. The air inbaled was first wasbed to remove dust. The noisture in the air explyet was condensed, and the liquid eollected in a thask smonnded by ice. At the monent of injection this liquid was filtered, and was then injected at the temperature of the laboratory, about $12^{\circ}$ C. If the animal was kept immovable from 12 to 16 louss, inflammation of the air passages was potheed. The linuid of the first lours eame frem a thomoghly smond long, and in the later homs from a diseased lung. The two were collected separately and tried separately. For one kilogram of the animal, for each houl, the mean quantity of fluil ohtaned was 0.88 grammes, varying from 0.28 to 0.48 grammes. It was grester in the heginning and lessened the longel the anmal was kejt in a fixet position. It was injecterl into the manginal vein of the ear of a rabbit ly means of a syringe, t5 c. c. being injected. When the injection did not exceed 40 to $50 \mathrm{c}$ e. the time oecupied by the injection was from 6 to 15 minutes. Experinents male by injections upon the log were negative with. ont exeeption. Experiments male mon the rablit producer lesions, but the relation between these and the injections was meertain.

Dastre and Loye, in $1 S S S$, (15), reported that they hat exposed one dog to 
the expred breath of andluer for six hemrs withont moting any eflects. They imocolated animals with the eomblemed moisture of respiration, as follows:

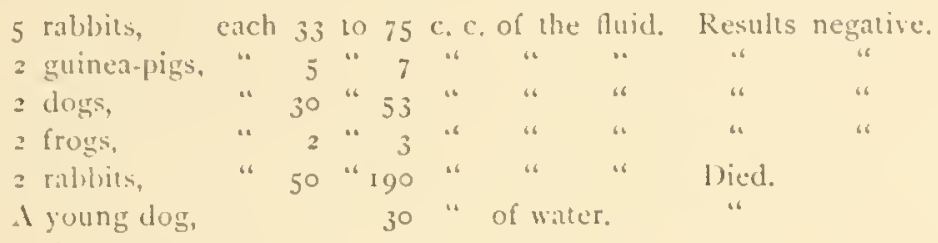

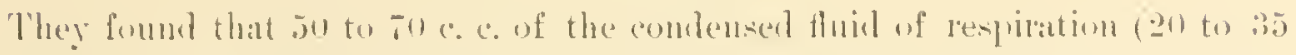

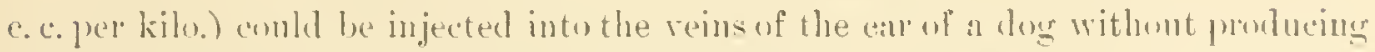

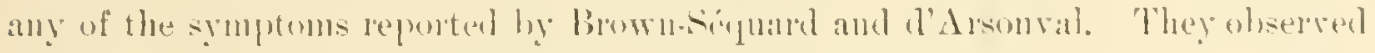

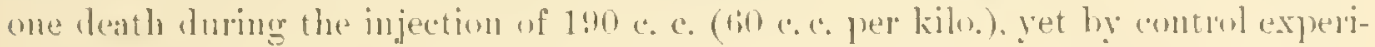
ments with water they whtaned a more remalukable result-at laphid death from the

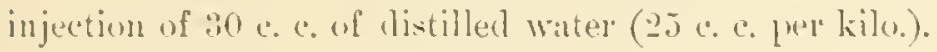

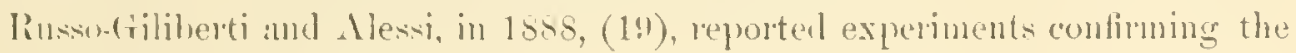
results obtained hy l)astre and luye.

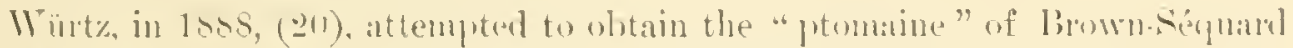

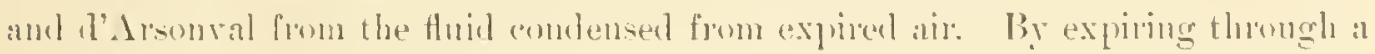
1 pere cent. solution of oxalic acil he obtained, besides ammonia, a volatile organic

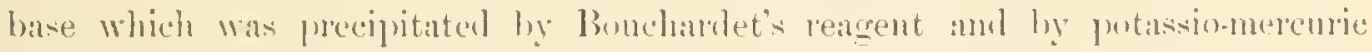

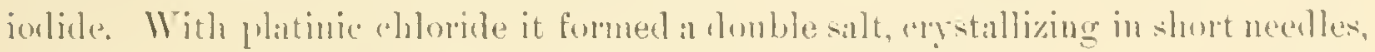
aud a soluble salt with auric chlorile. When heated to $100^{\circ}$ C. it rave off a peralial odor. 'This basic substance, he thought, might be regambel as a benco. manine.

Brown-séfuad and d'Aronval, in 1859 , (21), reported a new form of expredment by means of which they obtamed additional evidence in sulpurt of their for. mes statements. The new form of experiment consisted in contining animals

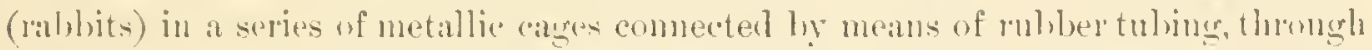
which a comstant coment of air is asprirated. The animal in the latet cagere of the? serics receives air that has traversed the entire series of eages, and is lompled with the impurities from the lunges of the animals in the other cages. 'This animal suce cmmbs, after" at time, to the atmopheric comblitions present. After anothor interal of some hours, the animal in the mext to the last eage also dies; the first amel secomb animals Insmally remaining alive. They combl not attribute the death of these

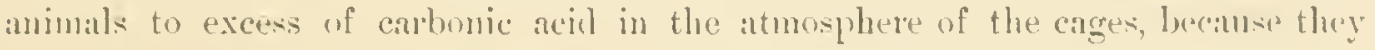
rarely fomm more than ? prele cant. of this gas in the last jall with small animale, or

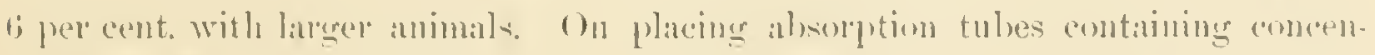
trated $\mathrm{II}_{2} \mathrm{SO}_{4}$ between the list two cages, the animal in the last eage remained 
alive, while that in the cagre before it was the first to lie. 'They conchuded from these facts, that the death of the animals was porduced ly a rolatile poison, which person is absorbed by the $1 I_{2} \mathrm{SO}_{4}$, which thus saves the life of the animal in the last "age.

They stated (22) that any alkali used to absorb cubonic acid from explued air would also change the orgunic poison, and proposed an apparatus by means of which the organie poison slonkl he supplieal to the fresh ar entering the jaus by rolatilizing it from fluid and ansed from the expired an.

Ton Infman. Wetlenhof, in $1888,(28)$, fonnd that when he injeeted large twantities of the comlensed fluil of respiration at $12{ }^{\circ} \mathrm{C}$., instear of at $87^{\circ}$ C. - intravenons

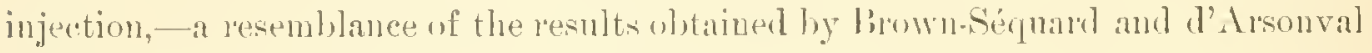
was produced. Under such ciremustances he ohserved muscle weakness, slowing of respiration, fall of temperature, and dilatation of the pupils, thongh the animals remained alive. IJe injected 10 rabbits with 6 to 80 c. c. of the fluid wamed to the body temprerature, all the results being negative. Three other animals were injected in the jugular rein-one receiving 28 e. c. of the fluid, another 25 c. c. of distilled water, and a thiml 50 a. a of distilled water. 'There was no difference in the symptoms noterl in the animals. Ile moticed symptoms of lepression only after injecting 50 c. c., or more, of the fluirl. In a series of 17 experiments witl inculations of from 30 to 50 a c e each of the fluid, in 12 there appeared hemoglohimuria; 6 of these died. As the result of lis experiments, lie concluder that the existence of a volatile poison in the expires air of healthy human beings has not been lemonstraterl by his experinents; this being a direct rontradiction of the results of Bromu-sicfuard and d'Alsonval, as were also those of Ilastre and Loye.

Uffelman, in $1858,(24)$, fond that there was a perceptible increase in organic matter in the atmosphere of a sleppingroom oceupied hy several persons for some hons, increasing in annut with the length of time the room was oceupied.

Lehmann and Jessen, in $1890,(25)$, collected 15-20 c. c. of comlensed fluid per hom from the breath of a person exhaling throngh a ghass spinal haid in ice. The flud was always clent as water, of lolless, and of neutral reaction. Nessler's reagent showed the presence of ammonia constantly, with gool teeth hut little, sometimes merely a trace, with hal teeth, more, though never more than $10 \mathrm{mg}$. of $\mathrm{NII}_{4} \mathrm{Cl}$ in one litre. Traces of HICI were also constantly fomnd. A small sediment remaned on eraporation, ranging from 39 to $86.4 \mathrm{mg}$. per litre of fluil. 'This they believed to originate from the ondass vessel; being probally calcium oxalate. They tuster its reducing power upon solution of permanganate of potash, making two control determinations. The first determination showed $3.6 \mathrm{mg}$. of $\mathrm{O}$ for the oxidation of $1 \mathrm{~L}$.; the second, 
4. 2 meg. of O. Thuy were mable to ohtain any alkaloid reaction in the comblensed

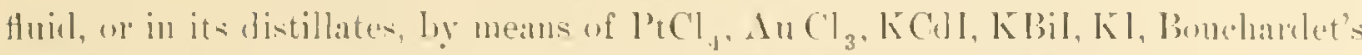

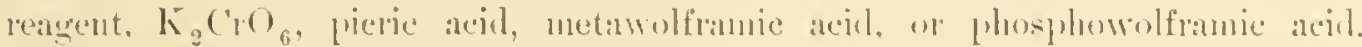
Only sublimate rave at timas an opalescence which, like the bellow colomation of

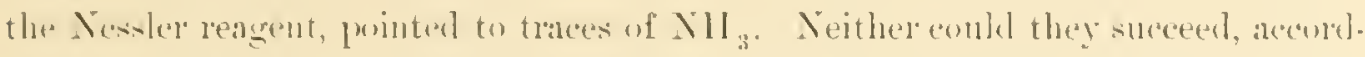
ing to the metherd of 11 int

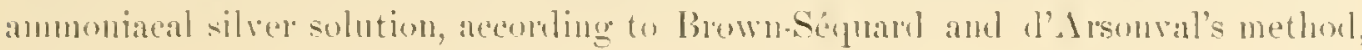

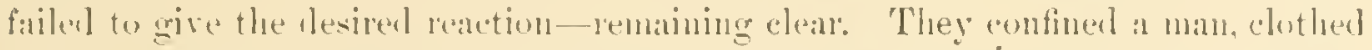

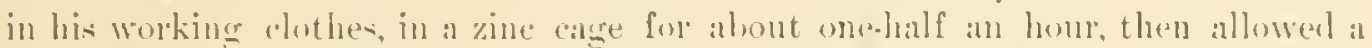
boy and girl to inbale the air from the cage. No ill weflects, except increase of respirations to :30 and to per minute, were notiesable. They hal complete negative results from inoculations of combensed thuid into animals.

Lipari and Crisafulli, in 1559 !), (26), reponted results which were in aceorel with those of Distre and Loye, and directy opposed to those of brown-sidpund and d'Arsomil. 'They could find no organic prineiple pussessing toxic purperties in the expireel breath of liealthy persons.

Margonty, in 1891, (27), reported the results of experinents similar to those of Hammonel, and also of experiments in injecting fluid combensed from expired air into animals. His results diul not rorespond to those reported by Itammond, and there was no evilence of toxic preperties in the injected fluids.

1laklane and Sulth, in 18:12, ( 25$)$, published an accomt of experiments in Whold an arretight chamber, if feet 2 inches high, - feet 11 inches widle, and i feet 11 inclies long, was employed. Simples of ail for analysis were drawn off through a tube placed in the wall of the thamber; ahout three feet from the floor. When one jersom remained in this chamber until the vitiation was from ten to twenty times as great as in the most crowder and worst rentilated fublic buildings, there was no pereeptible odor or sense of opluession. dir vitiated to such an extent as to completely prevent a mateh from burning had no aplreciable effect upon the subject of the experiment. In other experiments hypernea and other phenomena produced were apprarenty dne to the increased proportion of carbonic acid.

With rabhits wejghing 1500 grammes, hematmia was proluced when the amonnt of boiled distilled water injected passed beyond 100 c. c., and, therefore, SO c. c. were taken as the miximmm close.

To obtain the contensed liquid from the lungs, a man expires throngh a Liebig comlenser, in the jacket of which was flowing a stream of ice-cold water. 'The condensation liquid was collected in a flask, the bull, of which was buried in iee; and when the required amount (s0c.c.) hat been obtained, it was at once injected 


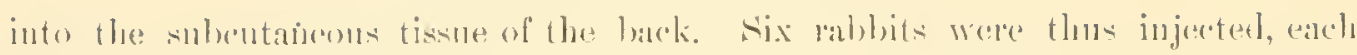

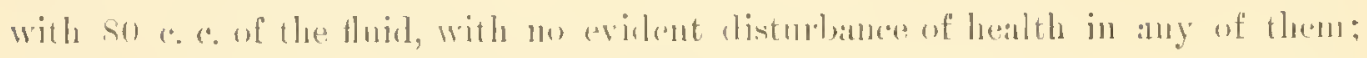

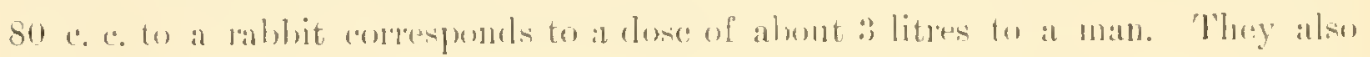

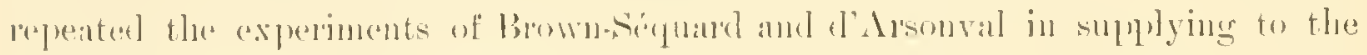

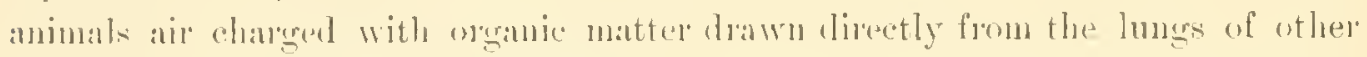
animals. 'Two large rabluts were plated in an air-tight chamber and a comrent of air drawn through this was supplied to two young rabbits moder observation; 110 effect was proturearl.

Merkel, in 1592, (29), reported an experiment in which fom air-tight gyas versels, of $1 \frac{1}{2}$ litres capacity, were connected by means of ghiss tubes; a monse lreing plated in ach ressel. Brotween the thirl and fourth ressels a Geissler absopption tule, containing sulphuric acil, was interpoed. Air was now drawn sowly through the ressels hy neans of an aspirator, so that the secomd monse breather the air from the first, the thind from that of the second, ete. The result wan, just as in the experinent of Brown. Sirpuarl and d'Alsomval, that the monse in the thind ressel died first, after 16-20 hours, while that in the fourth ressel jemained alive.

The emnclusion is drawn that, as the fourth monse remained alive, the death of the thinl cannot have been due to excess of carbonic acid, or deficiency of oxygen in the ail', but must have been caused by the fresence of some rolatile substance whicls is absorberl or destroyed by sulphuric acid.

The symptoms presented by the mice before leath were at first restlessness and grandually increasing aceteration of respiration, afterward slowing of resprira. tion, and finully spasmorlic deep respirations, becoming constantly less frequent until the advent of death. The puportion of canbonic acid in the air led through the glass vessels was not poisonons; it amounter in the highest aase to 1.5 per cent.

Merkel also conducted the expled breath throngh $\mathrm{HCl}$ with the idea of combining the organic matter with it, and beliered he was successul, but the quantities of the "salts" prodnced were so small that deternination of their chenical nature was inpossible. His experiments upon animals with this body, olstained from its combination by neutralization of the acirl, gave negative jesults.

He concludes that the expined breatl of healthy persons contains a volatile poison in extremely small quantities; being probably a base which is poisonoms in its gaseous state, but loses its toricity after combination with acids. His belief in the toxicity of the organic matter contained in the expired breath of human beings is based solely upon the results he obtained in the "Brown-fingual and d'Arsonval" experiment. 


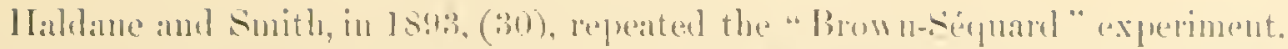
using five bottles, ableh of a calpacity of 1 to 13 litres, connereted by means of tuber. A momse was plated in each hottle and rentilation established threngh the whole

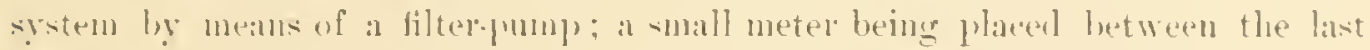
Inttle and the fump. Sprecimens of air learing the last hottle were drawn off' at

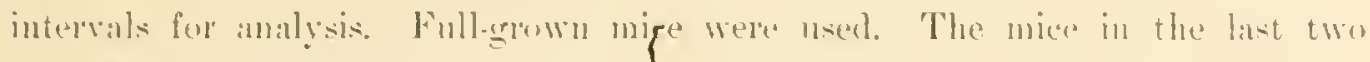
bottles were exposed to the full effect of the vitiated air for sos hours without detriment.

ln a second expreriment an absorption tube containing pumice-stone satulated with sulphuric achl was pheed between the last two bottles. This experiment

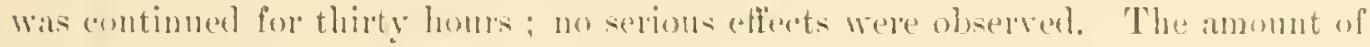
rentilation furnished was from 12 to 24 litres. prev homs. The mice remalneel mormal after having been in the buttle three bays and the pereentage of ardonic acid in the last bottle had valued from 2.+t to 5.2. averaginer about 3.

They state that these experiments, like theor former ones on labbits and man, are distinctly against the theory that a rolatile poison, other than carbonic actel, exists in the expliverl air.

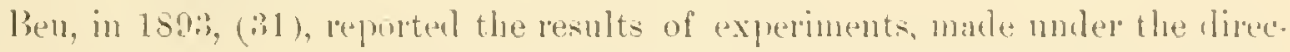

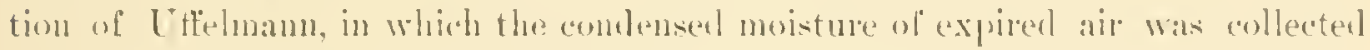
ly the methorls usmally employed, taking the preeaution to cleamse his apparatus with selution of KMnO and distilled water, and likewise sterilizing the apparatus before it was brought into use. The saliva is collected in a IToulff bottle attached before the eometenser. The amomnt of air explued, measmed hy a gas meter, was

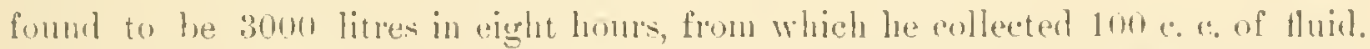
A distinct ammonia reation was obtamed upon the ahdition of Nessler's reagent. Nitrate of silver failerl to show the presence of ehlorine.

Its reducing power upun solution of permanganate of potash showed so $\mathrm{mg}$. of uxygen necessary to oxidize one litpe of fhubl, or 15 mgr. in $2+$ homs, which

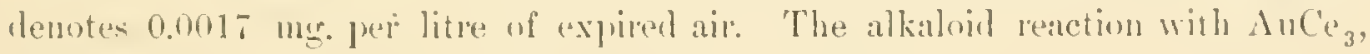
Ki, phosplomolybulate of potash, grave negative results.

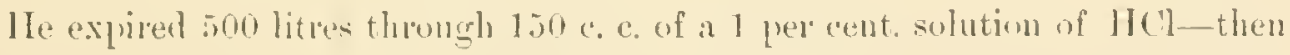
evaperating to dryess on the water-bath, a yellowish-hown deposit remained.

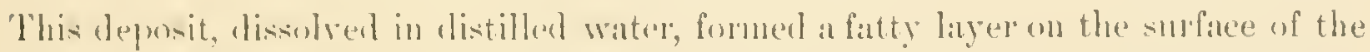

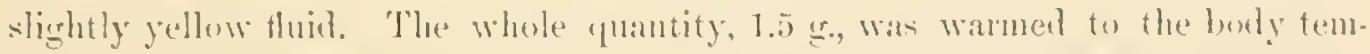
perature and injected muder the skin of the bakk of a white momse without pros-

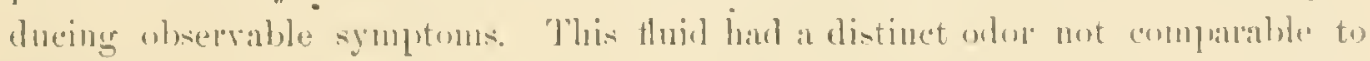
anything.

1le mext contined a monse in al sealerl grlass resisel, having at groble attacher 
with potasl solution to absorl, the carbmice acil; 3200 explations of air were conducted into the ghlass resiol during the three homs - no effect noticealile. In a second experinent the carbmic acid was not absolbed, the experiment hasting fomm houl's-110 efficet.

He repreated the "From-Séquarl" experinent, using white mice in four glass cages. The death of the animals, he believes, was due to changes in the tempera. ture and the accumulation of moisture in the jars. He believes the protection afforded by $\mathrm{H}_{2} \mathrm{sO}_{4}$ in Brown-Séquarl and l'A romval's expriments was due to its abstraction of the moisture from the air. An acute poisoning through the organic matters contained in the expired air he belieres to be impossible, or at least as not shown by anything in lis experiments.

Rauer, in 1899, (32), used white mice confined in glass vessels of abont $1 \frac{1}{2}$ litres calpacity, the bottom of which was coveresl with oats. 'The cork was perforated by three tubes: one of these passed lown near the bottom of the resise] and served for the entrance of the air ; the second terminated just below the cork and served for the exit of air; and the thind extended down to about the height of the animal but was usually closed, this was only used for the remoral of air for its chemical examination. In the beginning, thermoneters and hygrometers were used in the vesscls, but they were found to be unimportant and were abandoned. 'The whole apparatns was comnected with a large aspirator.

In an experiment with five animals and a rentilation of four litres per hour, the carbonic acid was found to amount to 9.3 per cent. after five hours. In another experiment with six amimals and with a ventilation of $2 \frac{1}{2}$ litres per hour, he inserter four absorption tubes with soda-lime between the last two jars, and a Geissler tube containing concentraterl $\mathrm{H}_{2} \mathrm{SO}_{4}$ between the fonrth and fifth. The sixth animal remained alive while the fifth died earlier than the fifth animal in the first experiment. He conchules that there is no organic poison in expired air, death being due to the excess of carbonic acid in the atmospheres of the jars.

Sanfelice, in 1898, (38), leporter that he had repeated the "IIammond" experiment, using a flask of about 5 litres capacity, the animal dying in six or seveu hours. He is mdecided as to the existence of a rolatile expiratory poison, though he thinks that other factors, for instance, lieat radiation, have an important influence upon the results.

Lübbert and Peters, in 1594, (34), reported that they had repeated the "Brown. Séquard" experiment, placing a grnineapigr in each of a series of fonr flasks. Between the thin and fourth flasks they placed a combustion tube through which the air coming from the thind flask was conducted, passing over redhot cupric oxide, to remove the organic matter. Before reaching the fourth flask, the air was 
again cooled hy combluting it through a cylinter surrombled with ire. In this mamer all moretme contained in the ar was combensed. From this cylinder the

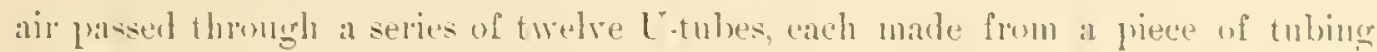

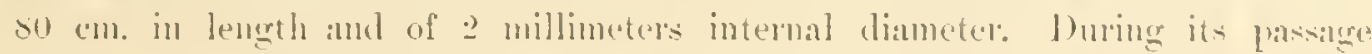

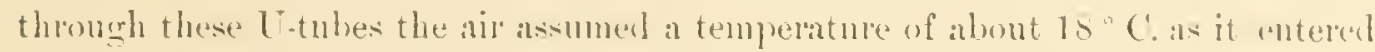
the fourtli thask. 'The results obtained by this arrangement substantiated the conchusons they had formest from andueting the experiment in the ordinaly manner, that the eamse of death was tracealule to the high per cent. of carbonic acil. "T'hes removal of the organic matter by combustion failed to save the life of the andmal in the last jar when the carbonic acid had increased to 11 or 12 per cent. Iftop the absurption of the carbonice acd by means of sodalime the last animal remained allive. They concluble, therefore, that the poisonous expriratery poison of brown.

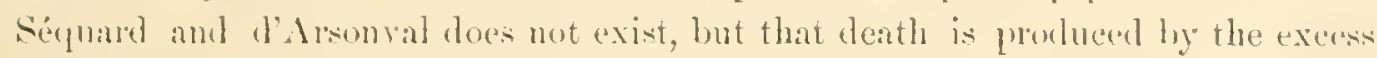
of earbonic acid in the lasks.

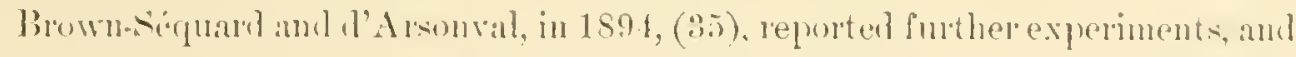

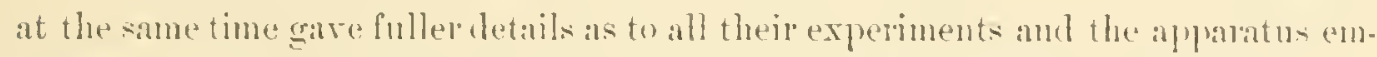

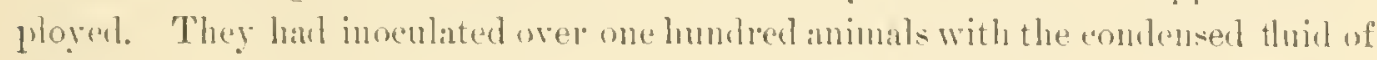
respiration and helieved in the truth of their former statoments als firmly as ever. They conble mot understand the failures on the part of the other experimenters. They emphatically reathrm that the expired bleath of man and animals contains a volatile organic prison poulueing the results repolted by them, amb that these results are not punduced by excess of earbonic acid or deficiency of oxyen in the air.

From the foregoing smmmary of the reports of clifferent experimenters, it will he seen that widely allierent result = have heen reported by them, but that the majonity of the later investigators agree in denying that the exhaled ineath of healthy. humam being or of animals contains a porsonous olganie alkakoinl, or any poisonoms product other than carbsule acid, yet in any case positive results require an explatnation wheh slan! ancount for the facts.

D Li. BTIREY'S FXPERIMENTS.

The furst experiments mate hy. In. Burgey were to ascertain whether the condensed moisture of air expired ly mon in ordinary, quiet respiration, anntams any fartienlate organic matters, such as microrganisms, eprithelial sobles, ete. 'Thu test for micro-organisms was makle by having an arblt man expire for foum twenty to thirty mimntes thromgh sterilimed melted gobatin, which was then preserved as a culture for from twenty to thirty days. In the first trial, six, aur in the secomb 


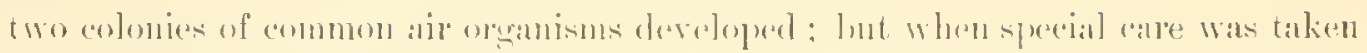

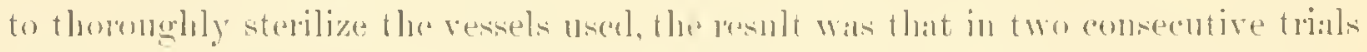

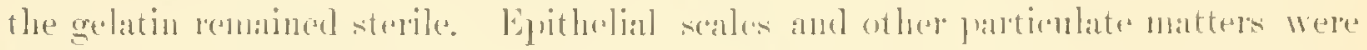

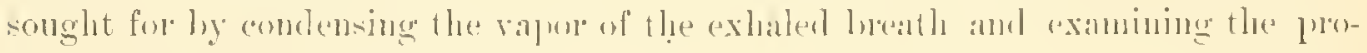
duet with the minerenge, with and withesut the use of stams. In six preparations

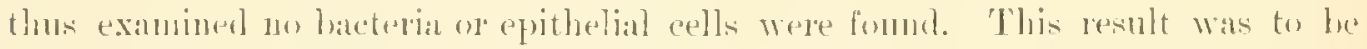
expected, since neither hacteria nol wetted particles pass into the air from the sur.

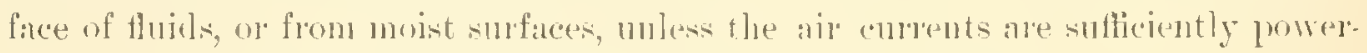
ful to tiske w' particles of the liquirl itwelf in the form of spray.

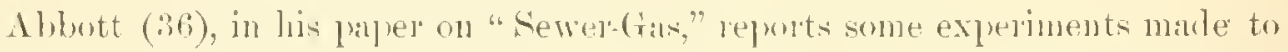

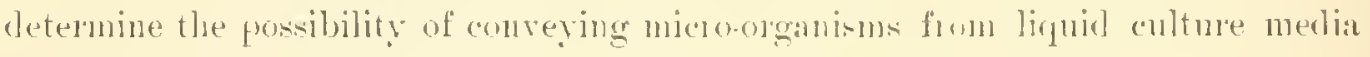
hy meams of a current of air hubbling through such unedial also ly means of ordinary baker's yeast inoculated into medial containing from 4 to 5 per cent. of glncose. No bateria were carried from the culture ly the explonling air-bubbles

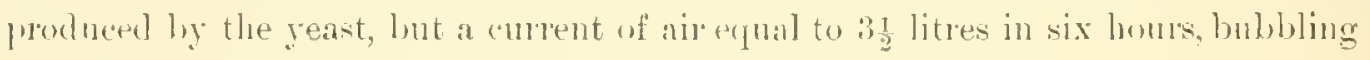
through a liquirl culture, carlied with it sone of the organisms in the ant ture.

The deteminations of ammonia in the combensed fluid of expired air, the est mation of its reducing power "pon solution of permanganate of potash, and its

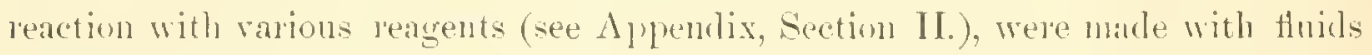
collected form a bealthy man, from a man with a tracheal fistula following excision of the lanyux, the expired an not coming in contact with the montlo or the pharyux, and from a man suffering from well nuaker tuberculosis of the lungs. In each case the amount of anmonia and of albuminoid ammonia in the fluid was very small, as shown by 'Table $B$ in the appendix, the average being, in grams per litre of fluid:

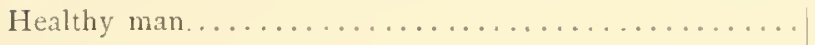

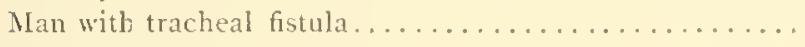

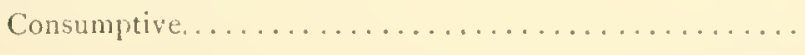

Free Amnonia.
$\begin{aligned} & .019 \\ & .00046 \\ & .003 .\end{aligned}$

.1luminoil Ammonia.

$.08 \mathrm{I}$

.00036.

.0034 .

The axilizable matter in these fluids, as shown by their reducing power on a solution of permanganate of potash, was determined, and the letails are given in Table $C$ in the aplendix. The average results, stated in milligmmmes of oxygen consumed per litre of condensed thud, are as follows: Ilealthy man, 10.72; man with tracheal fistula, 13.49 ; consumptive, 19.:5t. The high average for the man with the tracheal fistula is due to a single observation, for which the figure was 24.916. Onittiug this, the arerage for the three other olservations would be 9.68 . 


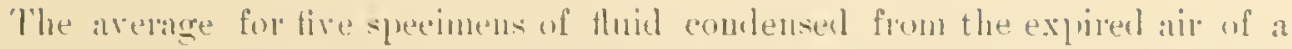

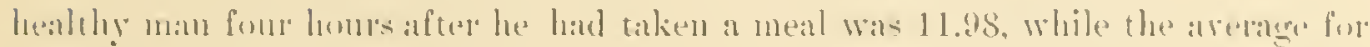
six specimens fan the breatl of the same man half an lould after the meal rats

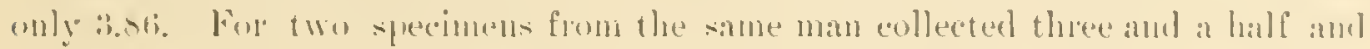

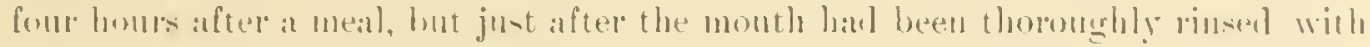
Wam water, the average was 2.45. These results imlieate that the ammonia and oxidizahle organic matter in the eomelensed fluid were, to a lange extent, due to

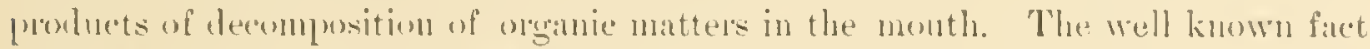

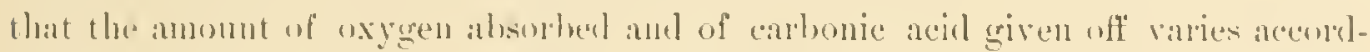

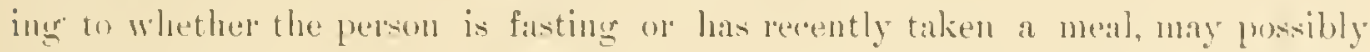

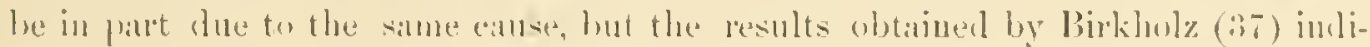

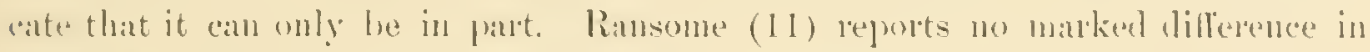

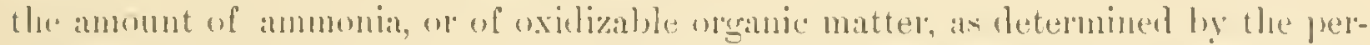
mamganate test, contained in the thide collected from the exhaled breatla soon after at meal amd in that collected form a fasting person. Ben (31) fonmd a much higher propertion of oxidizahle matter in the fluil condensed from his om breath (50

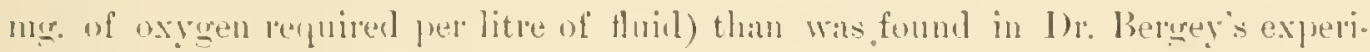
ments. Ilis results imlieaterl the exhalation of 15 mg. of organie matter in -4

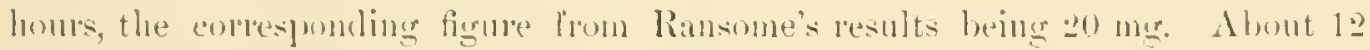
c. c. of fluid was eollected from abunt 33.s litres of air expinesl per hour, being nearly equal to the results obtained by ben (:31), who comblomsed lon e. co of the thinil from three colsic metres of anisexpiped in eight hours.

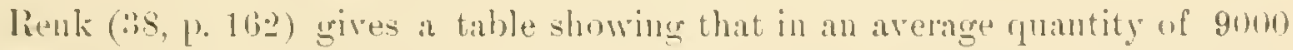
litres of ar expired in a day by a healthy man, the amount of moisture maly be from 200 to fou grammes, depenting on the temperature and relative moistme of

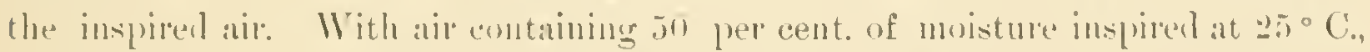
the anomut of moisture is $29: 3$ errammes, or about the result griven by Ben, referreal to ilores.

Ledomann and Jessen (2j) found that between 3 and 4 mg. of oxygen wore recpuired to one litre of fhuid to elfeet oxidation, and note that more ammonia was

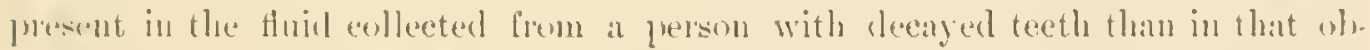
tained from a jerson whose teeth were somnd. Thle very consilerabhe differences in the anounts of ammonia and of oxidizable matter fomel in the fludis eondensed

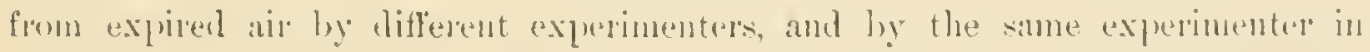
fluils obtained from the same person at ditherent times, are probably due tor sor. eral diflerent eanses and their (onmbinations. The amomnt of fluil comblensed per

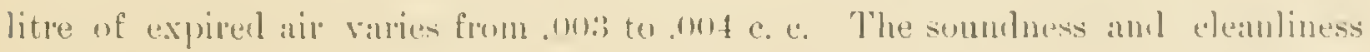
of the month and teeth intlence the amomut of ammonia and exidizable matter 
expired. Tandations in the anomut of organic matter contained in the inhaled air may posihly intluener the result, but this influphes must be slight. Ramsones results indirate that the arge, health, and rigne of the person maly affect the amomit

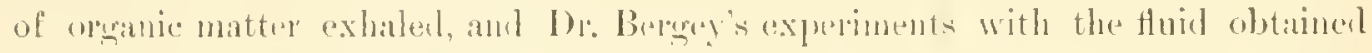

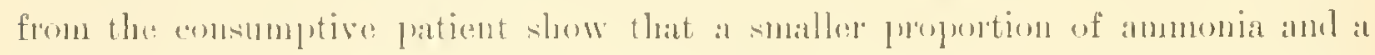
latger anomut of oxidizable matter were phesent in it than in the fluid collected from a healthy man. It should be rememhered, also, that it is extremely diflicult to obtain acrurate results in quantitative deteminations of such very minute amounts of ammonia and oxidizalle matters as are foumb in explined air, and a part of the differences in results obtained is no doubt due to munoted differences in the details of the experiments.

The results of tests for the presence of an onganic alkaluid in the condensed fluids olotined hy Dr. Bergey were regative, correnomding to those reprorted by Lehmann and descen (25) and by Ben (31).

The results of attempts to condense the moisture of the air in the hospital warl (Appendix, 111., 3) were not satisfactory, and the deterninations of ammonia in the fluid ohtained are not comparable, except that they show that the placing of a lust filter in front of the comdensing apparatus causes a marked reduction in the proportion of ammonia in the condensed fluid. The evalunation expalled the condensation excejt on days when the exterual ail was saturaterl with moisture, hence no moisture wis collected on clear days, but on such days some dust particles may have accummlated in the aplaratus which had no filter.

Some experiments wre made to determine the amount of oxidizalle matters in atmospheric: ali, the results of which are given in Table $\mathbf{F}$, in the appendix. These results differ greatly, some showing a mere trace of organic matter, others showing an anount which consumed .204, .840, and .5is grammes of oxygen per $1000 \mathrm{cbm}$ of air. 'The great differences in the amomt of ammonia in air fond by different olsservers as tabulated by Renk (38, 1).40), and as rejorted by Remsen (39), Niss Tallot (40), Nekan (41), Archarow (42), and Abbott (36), while evidently in part due to differences in methods of experinent, must be more largely due to differences in the amount of organie dusts in the air in different places or in the sane place at different times, than to differences in the anount of ammoniaeal gases or organie raluors in the air, and the same is true with regard to the differences in the amount of oxilizable organic matter in the air reported by Angus Smith (12), Canclly and Mackey (43), and other's.

Several series of experiments were made to detcimine the nature of the gaseous mixtures in which small animals die with symptoms of asjlyyxia. The first of these series were repetitions of the experiments reported by Hammond and described 
above. Vice and sparows were used. The details are given in the dpuendix

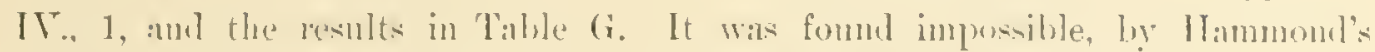

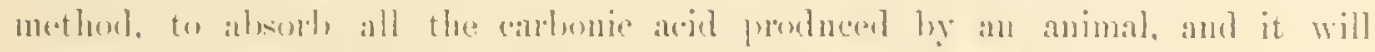

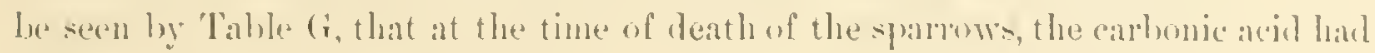

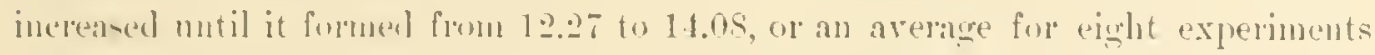
of $13.2+$ pere cent. of the air, while the oxyen had diminished to from 5.25 to 5.61 .

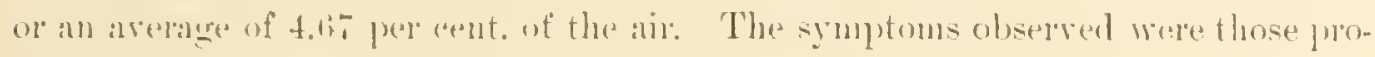
duced by insutticiency of oxyem, and there was no evidenee that death was due to organic matters in the air. The duration of life in the animals onfined was from there to six homs, heing moln longer than that reported hy llammond using a slightly smallar vestel, riz. less than one hour, and corresponds to the results reported by sinfeliee (3:3), whe formd that the animals lived fom six to seren homrs. When the experiment was so moditied that all the carbonic acid wis removed fom

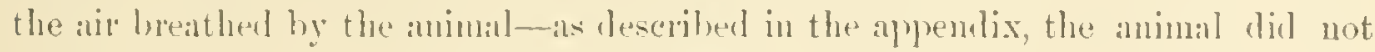
die in seren homrs, althungh the perentage of oxygen had been redneed to 18.85 , as shown by Tilhle 11 in the appendix. These experiments, therefore furnish no

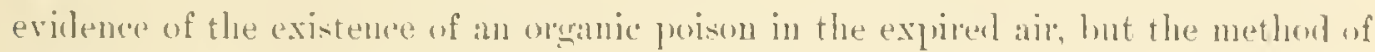
ahsorbing earbonic acil by an alkali is sait by Brown-serquarl and d'Arsonval (2) to change the organic poison which they chan to be present, and hence these exprements are not condusive on this point.

A series of experiments was also mate mpon mice and sparows to determine.

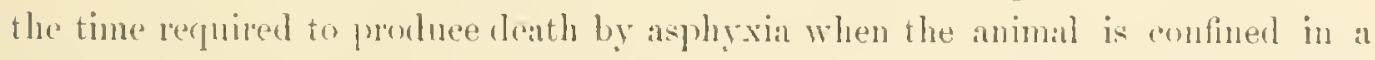
jan of known calpacity, when no provision is male for renoving anbonic aciel and moistme, or for supplying fresh air, and also to determine the proportions of earbonic acil am of oxygen existing in the enclosed air at the time of death. In commertion with these experiments it was also songht to determine the influence which high or low temperatures of the ar would have on the result. The data derived from these experiments are shown in Tible $I$ in the Appentix.

A mumsa weighing 21 grams, plated in a jar of 1000 c. c. capacity at a tem. [erature of $30^{\circ} \mathrm{C}$, lived four hours; in a jar of 2000 c. e. capucity a similar monse lived seren and a half homs: in one cane when the rom temperatme was $25.5^{\circ} \mathrm{C}$. in another case when the room temperatmes was $5^{\circ} \mathrm{C}$. In the first case death

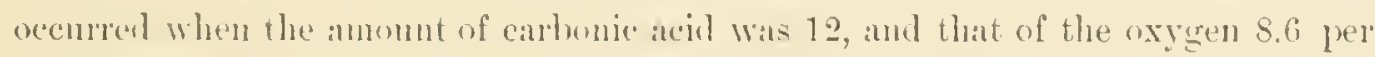
cent. of the mixtme; in the seench ease, the proportions were 18.2 per cent. of earbonic acil amb 6.t pere cent of oxyen: and in the third case, 10 per cent. of car-

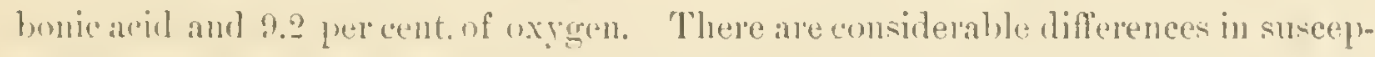
tilility to the effects of an impure atmosphere in individual mice, but when a monse is placed in a closed jar containing ordinary atmospheric air, the time required to 


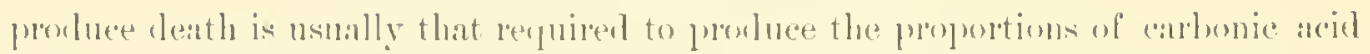
and of oxyegen indieated ahowe, and, hesters, is in proportion to the size of the jar.

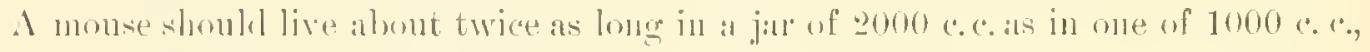
other comblitions as to temperature, etc. heing the same, and commencing with orlinary atmospluerie air.

The duration of life in the experiments with atnospheric air in elosed vesseds,

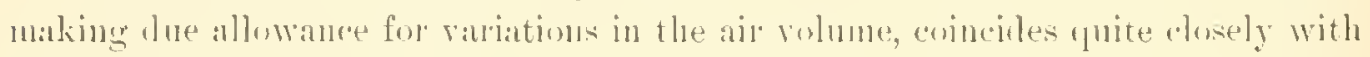
the duation of life in the "Ilammond" experiment. "Tlue air analyses at ateath of the animals in the two forms of exprerment, also gave very similar results. In comproing the results shown in 'lables G and I, it is necessily to lear in mind the differences in the size of the jars and in the weight of the animals usen in the sereral dxperiments. As a gremeral rule, the animal dien when the carbonic acd lass increased to hetween 12 and 18 per cent. ant the oxygren has diminisherl to between 5 and fi prer cent. Is deatl due to the increalse in the carbonde acid, or to the diminution in the oxygen, or to both?

Sonte data for answering this question are presented in Table L, which slows the results ohtamed by placing animals in galseous mixtmes contaning varions poportions of ealunic acid, oxygen, and nitrogen. The animals experinented on were mice, rats, rabbits, guneapigs, and sparows. From this table it will be seen that the diniuntion in oxygen in the inspired air was the most inportant factor in forlucing death, and that so long as the oxygen is present in the proportion of 6 per cent. and upwards, earbonic achl may be present to the amount of 20 per cent. without cansing death. When the carbonic acid forms muel more than 20 per cent. of the mixtme, say 30 to 40 per cent, the oxygren must form at least 12 per cent. to preserve life.

If the proportion of oxygen in the mixture be reduced, the duration of life is shortenerl, as will be seeu from the following extraet from 'Table L:

\begin{tabular}{|c|c|c|c|c|c|c|c|c|c|}
\hline \multirow[t]{2}{*}{ No. } & \multirow[t]{2}{*}{$\begin{array}{l}\text { Weight } \\
\text { grams. }\end{array}$} & \multicolumn{3}{|c|}{$\begin{array}{l}\text { At beginning of } \\
\text { experiment. }\end{array}$} & \multicolumn{3}{|c|}{$\begin{array}{l}\text { At end of } \\
\text { experiment. }\end{array}$} & \multirow[t]{2}{*}{$\begin{array}{l}\text { Duration of } \\
\text { life. }\end{array}$} & \multirow[t]{2}{*}{$\begin{array}{l}\text { Capacity of } \\
\text { jar. }\end{array}$} \\
\hline & & $\mathrm{CO}$ & O. & $\underset{\%}{N}$ & $\begin{array}{c}\mathrm{CO} . \\
\%\end{array}$ & 0. & $\mathrm{~N}$. & & \\
\hline 8 & 18 & ० & II. 35 & 88.65 & $6.5^{6}$ & +14 & 89.3 & $3^{\frac{1}{2}}$ hours. & 2280 C. C. \\
\hline 9 & 15 & 0 & I 1.35 & 88.65 & 7.43 & $3.5^{8}$ & S9.0 & $+\frac{1}{6}$ & 2280 \\
\hline 10 & 17 & 0 & I 1.35 & 88.65 & $7 \cdot 5^{2}$ & 3.16 & 89.2 & $4 \frac{1}{6}$ & 2280 \\
\hline
\end{tabular}

In these experiments the proportion of oxygen was reduced to about oue-half of that in the normal atmosphere, and the duration of life was also reduced about one. 


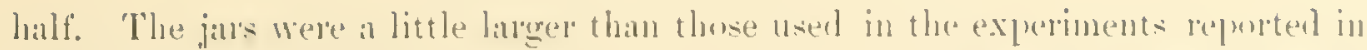
'Table I. The propoltion of oxygen present at the deatlo of the animal wats hetween

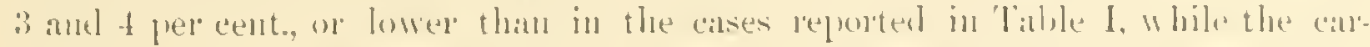

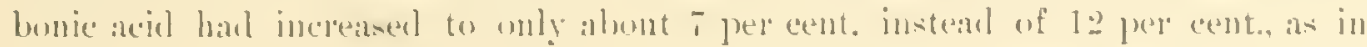
Table 1. The smalled proportion of carbonic aciel laere present secems to have?

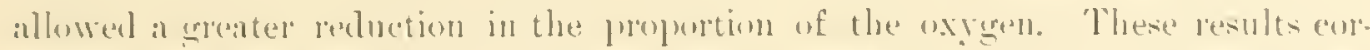
rejomel with those ohtained with mixtures of grases by Paul bert ( 7 , page jls),

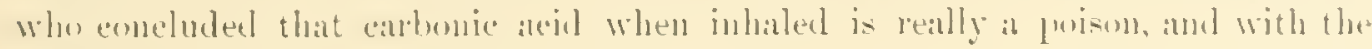

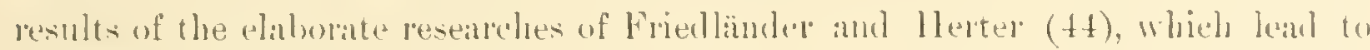
the simbe comelusion.

In this connertion the observations of lichardson (s) are of interest. His

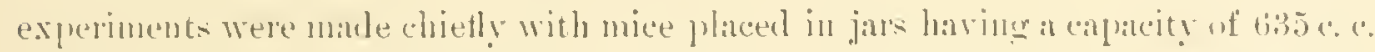

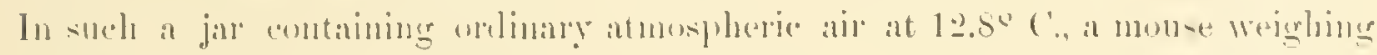

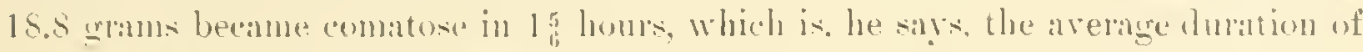
life muler such comditims. It a temperatme of ti.to (.. the animal dies in forty

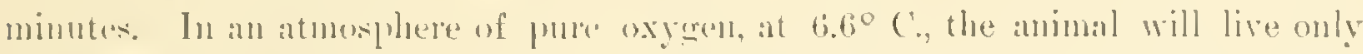

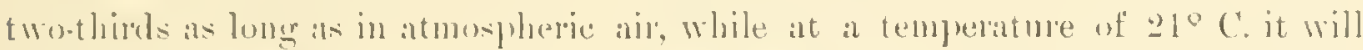

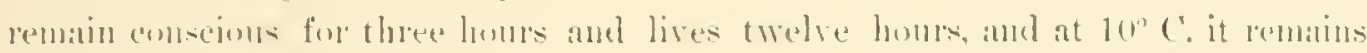

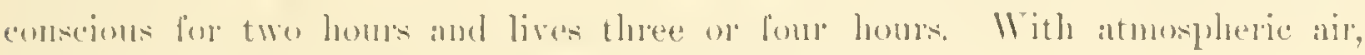

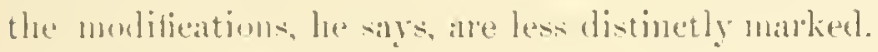

The lesulto of -imilat axperiments male with abe and with diflepent mixtures

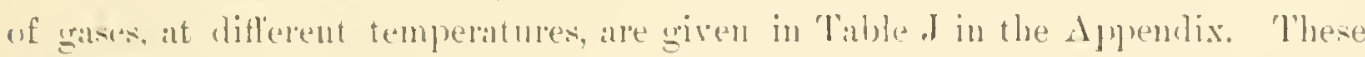
results slow that the duration of life, in confined placess is intluenced to a very markes degree by temperatme. and that this influence is independent of the rieds.

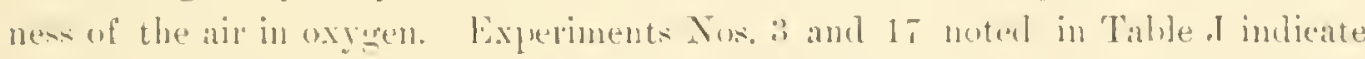
that an atmosphere consisting of 90 per cent. of oxygen and lo prep cent. of nitrogen does not smpont life quite an long as does orelinary atmospherice air when the temferatme is 1) C.. While at a temprebatme of $50^{\circ} \mathrm{C}$. the atmosphere rich in oxyeren sulports life mueh longer than the ordinary atmosplore, as is shown hy experiments Nos. o and 15 iu the table. 'Tho ermolual rise in temperature wheh must have taken place in the experiments previously referrenl to, was probilly but a small faretor in the results obtained, hecanse, as shown in the tahles for those experiments, the duration of life and the proportion of oxyegen present at death hear a constant relation to each other". 'This they fail to elo in the "Richardson "xperiments.

The toleration which is acpureel hy an animal hy prolongerl sojomm in an

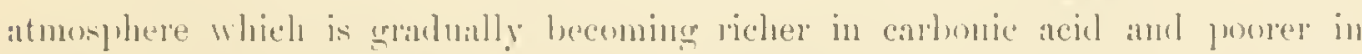
oxygron, makes it improsible to emmpare the results as to dumtion of life in such experinents with the results of experiments in which the animal is placed at once 
in an atmosphere containing almornal purportions of these galses, so far as the

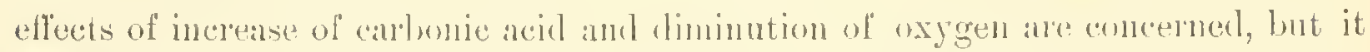
is evident from the results reported in Talbles I and J, that death does not ocenr in atmospheres in which the carbonic alcill does not exceed 10 preb cent. unlesis the oxygen is reslueed to below $t$ per cent of the mixture.

A series of experinents was mate by injecting into animals the fluid condensed from the air expired by healthy persons and ly a man with a tratheal fistula, from whom it was possible to olstain such fluid withont contamination from the exhalations from the mouth. The cletails of these experiments, and of the results obtaned, are given in the Aprenclix, TI. 'The injections were male into the general circulation in labl]jits, and into tle peritoneal cavities of rabbits, guinea. pigs, and white rats, following the methods employed by linownserund and d'Aisonval (15) and by v. ITofmann- Tellenhof (29). 'The number of aninals inoculated with the comlensed fluil of respiration was thirteen, in fous sets. 'The fluid was collected with the greatest care in is sterilized alpuaratus; subseruent cul. tures male from it inclicating that it was sterile. It was warmed to about $35^{\circ} \mathrm{C}$., before injection. The proportion injected, as compared with the boly weight of the animils, was, in sone instances, less than that used by Brown-sequard and d'Arsonval, in other's greater than the smallest quantities used ly them with fital effects. The results obtaned, with the anomin of flud injecterl in each case, are shown in 'Table $K$, given in the Aprendix.

In most of the auinals no observalule disturbance of health was produced, nor did this condition alter in the conse of several months during which they were kept under observation. One rabbit died thirty-two days after laving received an injection into its peritoneal carity of 5 c.c. of flud comelensed from the breatl of a man with tracheal fistula. 'The results of post-mortem eximination showed focil necrosis in the liver, but no ecolymoses and hemorlages in the lungs and intestines, such as are l'eported as a characteristic result of such injections by brown. Séquard and d'Arsonval. Three other rabuits which had receiver injections of the comdensed fluid, and hat remained apparently perfectly well from six weeks to seven mouths, were killed and careful post-mortem examinations male. The resnlts of these examinations showed that there was no special disease or degreneration in the organs of these animals.

The results of this series of experiments are, therefore, in accord with those reported by v. Hofmann- Wrellenhof (2:3), and indicate that finid condensed from the pulmonay exhalations of man has no toxic or specially injurious effect when injected into animals, and that these is no evidence that such fluid contains an organic poison. 
The attempt to collect comdensol moisture from the air of the losplital ward

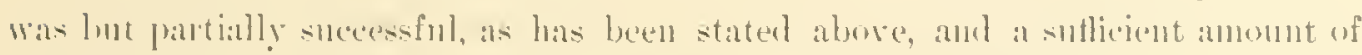

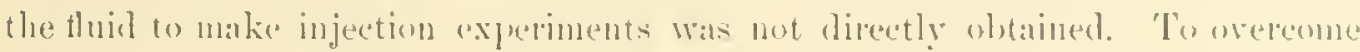
this difliculty the air of the warel was draw ored sterilized glyerine which was then diluted with distilled water, and the prorluct injected into animals. 'The results are shown in Table E in the dpenelix. Three of the animals thus injected died between four and six werelis late'p but the post-mortem examinations failed to show any clear comnection hetween the injection and the fatal result. As it wis shown that the fluid collected and the dust in the warl contmined several specoies of bacteria, inclueling pathegende forms, it was to be expected that more definite results woukl have been obtamed, but the power of the cells and tisones to resist the patlogenic organisms was suffecont to prevent their action in calch case,

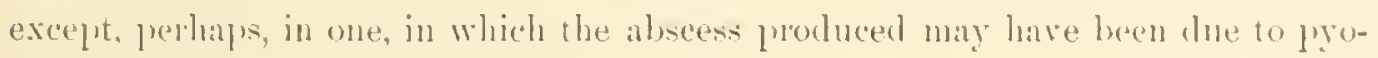
genic bacteria in the injected fluid.

A number of expreliments were makr in which animals, in a series of hell jars, were cansed to breatle aid which becane more contaminaterl with the purbets of

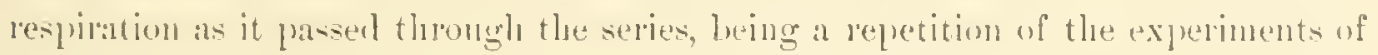

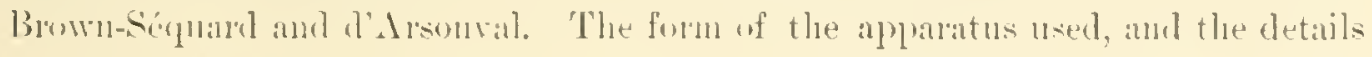
as to the gesults olstained in each of the thirty-three experinents of this limel, ane griven in the Aplendix, Vll. 'These experinents were perfomerl on spanows, mice. grumea-pigst, and rahbits.

It was very ditlicult to keep the aplatratus absolutely andight, and, no doubt, some of the dircerepancies in the results, at leats for the carlier experinents, are due

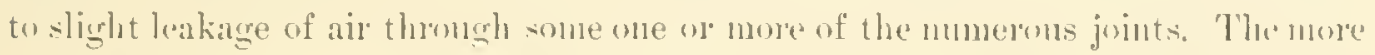
concordant results in the later experiments indicite that these defects had been obriater.

In the great majority of anes death was eviclently dhe to the dinimution in the oxygen and increase in the carbonic acju-the proportions of these gases presont in the jall when an aninul died being about the same as in the expreriments reported in 'Table I, i. e. the oxygen was reduced to between 4 and is per cout. and the earbonic acid incleased to from 12 to 1 t per cent. 'Tlae nuche of lleath of the amimals was similan to that uherved in slow applyxiat, and the results of careful post-montem examination and microseopie investigation do not indicate the eflects uf any "lyallie poison.

The insertion of absolpetion tubes containing canstic alkalies hetween the bell

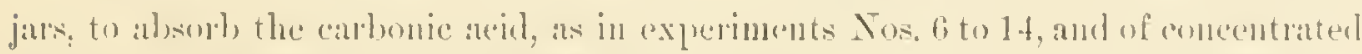
sulphuric acid, as in experinents Nos. 15, 18, and 19, dicl nut grive results corresponding to those reported by Brown-sicynad and d'Arsonval. 
In these experiments the animals were in an atmosphere of less pressure than

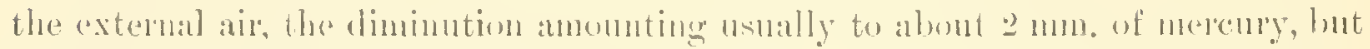
there is no reason to suppose that this exerted any influence npon the results obtained.

Experiments Nos. 1\%, 18, and 1! slow that the mice became halituated, to a certain extent at least, to the comlitions muld which they were placod, and conld live in an atmosphere which was almost inmorliately fattal to a fresh mouse placed in it. Thlis had alleady betn demonstrated hy bernard (5). In the calse of several mice, this power to resist the fonl atmonghere was preserved for forn three to eight days after they had heen renosed from the jar, wo that they hat a certain degree of permanent immunity (See experiment 1s, C.). Experiments Nos. 20 to 28 were made to see if it was posilyle to develop - nch an jummity, and the results cobtained inclicate such a possibility, lut further investigntion will be necessingy to settle this important point. At plesent it is uncertan to what extent the immmity olserved in a few mice was possessed by them before they were experimented on, or was produced by their first exposmes to the ritiated atmongheres.

Fron the datal accummlated with reference to the composition of the atmos. phere in these bell jar's by repeated analyses at slont intervals, comprared with the results reported by Browu-Sinnard and d'Arsmonl, it seems probable that the cases in which the last animal in the series survived some of the others, and a low per. centage of carbonic acid was found in the jan, shonld be attributed entirely to de. fects either in methols of air analyses or in the aplaratus, or in both. If, howerer, the life of the last animal was apparently sared hy $\mathrm{II}_{2} \mathrm{SO}{ }_{4} \mathrm{in}_{\mathrm{H}}$ Dr. Bergey's experiments, it was due to leakage in the connections from the increased resistance cansed by the interposition of the alsorption tube. This is an important fact, which is in direct "lposition to the theory of Brown-kiduand and d'd l'sonval with regard to the influence of the $\mathrm{H}_{2} \mathrm{SO}_{4}$ in the absorltion tubes. The great differences in individual susceptibility of different animals must also be taken into acoonnt in consilering the results of these experiments; for example, in experiment No. 11, spanow No. 4 died when the pereentage of oxygen was 9.34, and that of carbonic a wid was only 2.79, while No. 5 lived until the percentage of oxygen was reduced to 8.58 . In some mice there seems to be a very consiclerable immunty against the asphyiating effect of an atmosphere pou in axygen and rich in carbonic acid.

The duration of life of indiridual anmals in experiments of this kind depends upon the size of the bell jass in relation to the size of the animal, on the anomnt of fresh air supllied, on conditions of temperature and mojsture, and on indivilual peculiarities of the animal-and it seems probable that rariations in these factors will accomut for the different results obtainel by lifferent experimenters. The symptoms in the animals which died were those of death by slow aspliyxia. 
In experiment No. 3:3, with a series of six rablits contined for forty-two days.

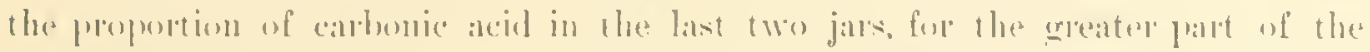

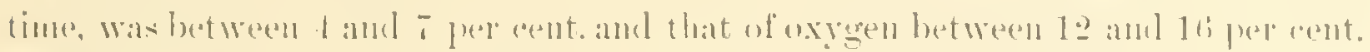

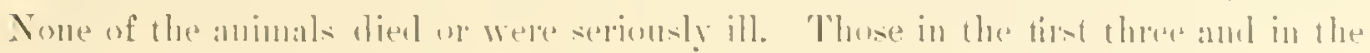

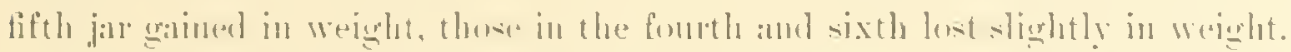

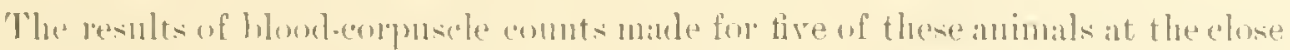
of the expreriment, and andiut thirty-e

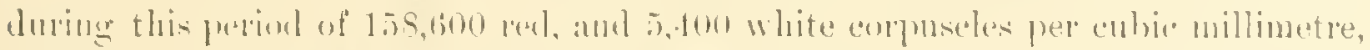

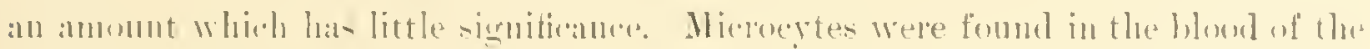

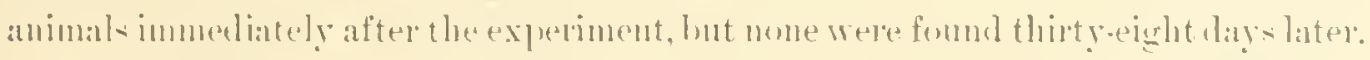

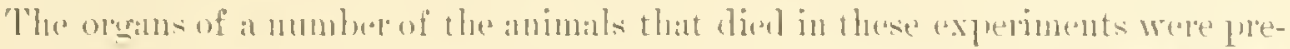

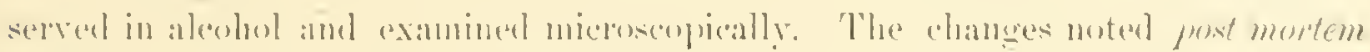

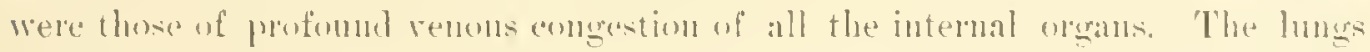

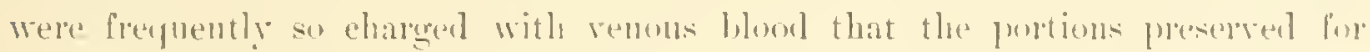

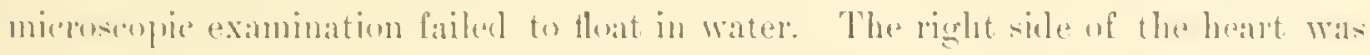
nstlally dilated with a latge tirm venous olut. the left rentricle was in most instances contrateded. The liver, on imeivion, bled freely, as lid also the kielneys and spleen,

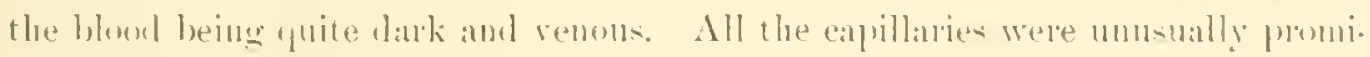
nent, being tilled with remens loked ; this was particularly noticeable in the small intestine, and in the membranes of the brato.

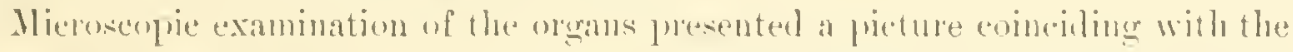

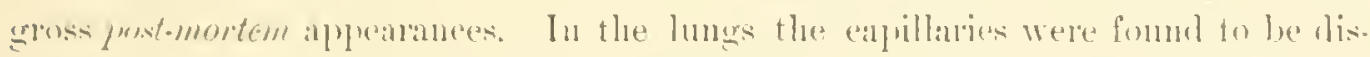

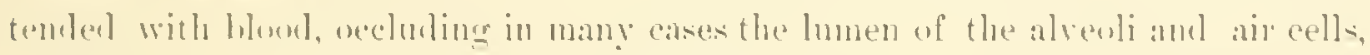

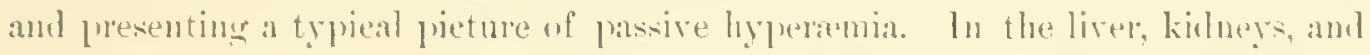

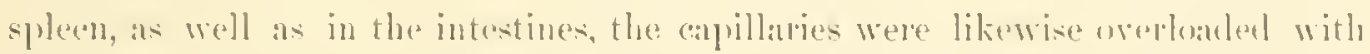
bloul. Pathologioal changes were hut rarely noted, and some of these, such as slight proliferation of comnective-tisise elements between the tubules of the kirluey,

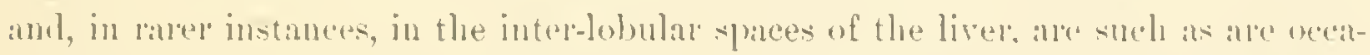
sicually foumd in animals which have not been subjected to such contitions, and may, therefore, lave existed in the animals at the heginuing of the experinent. All the changes which were enstantly present may properly be attributed to the action of the eabbulic: acel and the low pereentage of oxygen in the atmosphere, interfering with the cirenlation and ariation of the hloud. The lesions reported by brown.

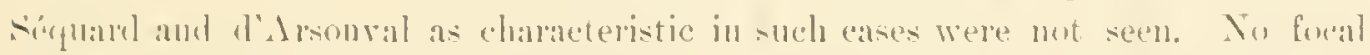

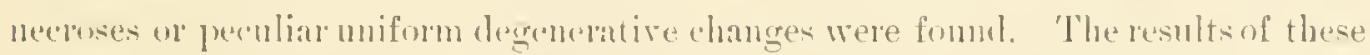

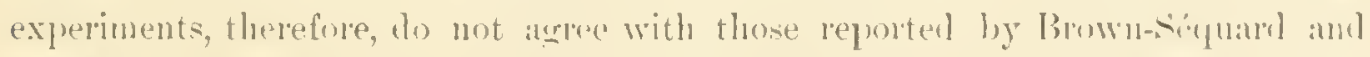
l'Arsonsal-and furnish no evilente of the existence of an organic proison in the air expired by animals. 
CONCLUSIONS.

I. The results ohtanined in this reseacele inclicate that in air expired by

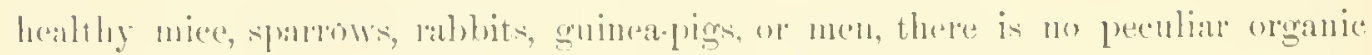
matter which is prisomens to the animals mentioned (excluting mant), or which temels to produce in these animals any spereial form of disease. The injurions effects of such air olserred appeared to be due entirely to the diminution of oxygen, or the increase of carbonic aciot, ar to a combination of these two factors. 'They also make it very improbable that the nimute ynantity of organic matter contained in the air exphed from hmman hungs has any deleterions influence "pon men who inlale it in oldinary rooms, and, heme, it is probably unnecessary to take this factor into aceome in proving for the rentilation of such rooms.

II. In orlinary quiet lespination, no bacteria. "pithulal seales, or particles of dearl tissue are contained in the expired air. In the act of coughing or sueezing, such organisms or particles may probably be throw ont.

III. The minnte pluantity of ammonia, of of combined nitrogen, or other oxidizahle matters, fonnd in the condensed moisture of human breath appeas to be largely due to products of the recomposition of organic matter which is constantly going on in the moutl and pharyns. This is shown by the effects of cleansing the mouth and teeth upon the amount of such matters in the condensed moistne of the breath, and also by the differences in this respect betreen the air exhaled thromgh a tricheal fistula and that expired in the usual way.

$\mathbb{T}^{r}$. The air in an inhalfited rom, snch as the lospital ward in which experiments were male, is contaminated from many sonres besides the expired air of the ocenpants, and the most important of these contuminations are in the form of minute particles or dusts. The experiments on the air of the hospital warl, and witl the moisture condensed therefrom, show that the greater part of the ammonia in the air was probably connected with dust particles which could be remored by a filter: 'They also shored that in this dust there were microorganisms, including sone of the bacteria which produce inflammation and suppuration, and it is polbable that these were the only really dangerous elements in this air.

T. The experinents in which animals were compelled te breathe air ritiated by the products of either their own respination or by those of otber animals; or were injected with thuid coulensed from exprired air, gave results contrary to those reported by Lammond, by Brown-Séquad and d'Alsonval, aud by Merkel, but con'esponding to those reported by Dastre and Loye, Russo-Giliberti and Alessi, IIofmann. Wellenhof, Raner, and other experimenters referred to in the preliminary historical sketch of this report, and make it improbable that there is 
any peculiar rolatile poisonons matter in the air expired by healthy men and animals, other than carbonic achl. It must be horne in miml, howerer, that the results of such experiments npon animals as are referred to in this report may be applicable only in part to human beings. It does not necessarily follow that a man wouk not be injured by contiunally living in an atmosphere containing ? larts per 1000 of carbonic acid and other products of respiration, of entanrous excretion, and of putrefactive lecomposition of organe matters, because it is fommel that a monse, a guinea-pig, or a rabbit, secms to sulfer no ill effects from living uncler such conditions for sereral dirs, weeks, or months, hut it does follow that the evidence which has heretofore heen supposed to demonstrate the evil effects of bat rentilation upon human health shonkl be carefully serutinized.

V1. The effects of retuction of oxygen and inerease of carbonie acil to a eertain degree appear to be the same in artificial mixtures of these gatses as in air in which the change of proportion of these gases has been produced by respiration.

VII. The effect of hibit, which may enable an animal to lire in an atmosphere in which, by gralual change, the proportion of oxygen has become so low and that of the earbonic achl so high that a similar animal brought from fresh air into it dies ahmost immediately, has been observed before, hut we are not aware that a continuance of this immunity produced by it hat been previously noted. 'The experiments reportel in the Aplendix, VII., 17 to 28 , show that such an immunty may either exist nomally or be produced in certain mice, but that these cases are rery exceptional, and it is very desimble that a special researeh shomb] be male to detemine, il possible, the conditions upon which such a continunce of immunity depents.

VIII. An excossively high or low temperature has a decildol tefect upon the production of asphyxia by dininution of oxygen and increase of carbonic acid. At high temperatures the respiratory centres are affected, where evapolation from the skin and mucous surfaces is checked hy the air being saturated with moisture; at low tempelatures the consumption of oxygen increases, and the demand for it becomes more nrgent.

So far as the acutc effects of excessively foul air at high temperatures are concerned, such, for example, as appeared in the Plack IIole at Calentta, it is probable that they are due to substantially the same causes in man as in animals.

IX. The proportion of increase of carbonic acid and of diminution of oxygen, which has been found to exist in hally rontilated churches, schools, theatros, or barracks, is not sufficiently great to satisfactorily account for the great discomfort which such contitions produce in many persons, and there is no evidence to show that such an amount of change in the normal proportion of these gases has any 
influence 1 pon the increase of disease and death-rates which statistical evidence has

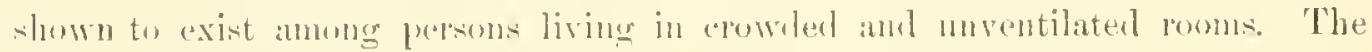
Report of the Comminsioners alpointed to inguire into the regulations affeeting the sanitary combitions of the british Army (1), properly lays great stress on the fact that in civilians at solliers' ages, in twenty-four large tomns, the death-rate per 1000 was 11.9, while in the foot-guareds it wats 20.4, and in the infantry of the line 17.9, and showed that this difference was manly due to diseases of the lungs acemring in soldiers in crowded and unrentilated barracks. These observations have since been repuatedly confinmed by statistice lerived from other anmies, from prisons, and from the deatl-rates of persons engaged in different oceupations, and, in all cases, tuberenlar disease of the lungs and pmenmonia are the diseases which are most prevalent among persons living and working in mventilated rooms, mless such persons are of the Jewish race. But consumption and pneumonia are cansed by specific bacteria, which, for the most part, gain access to the arrepassages by alhering to particles of dust which are inhaled, and it is probable that the greater liability to these diseases of persons living in erowded and unventilater rooms, is, te a large extent, due to the special liability of such rooms to become infected with the arems of these disenses. It in, howerer, by no means demonstrated, as yet, that the only deleterious effect which the air of crowded barracks or tenement-house rooms, or of foul courts and narow streets, exerts upon the persons who breathe it, is due to the greater mumber of pathogenic micro-organisms in such localities. It is quite possible that such impure atmospheres may affect the ritality and the bactericidal powers of the cells and fluids of the upper air-passagres with which they come in antact, and may thus preslispose to infections, the potential causes of which are almost everywhere present, and especially in the upper airpassages and in the alimentiny canal of even the healthiest persons, but of this we bave, as yet, no scientific eridence. It is very desirable that researches should be made on this point.

X. The discomfort produced by crowled, ill-rentilated rooms in persons not accustomed to them is not due to the excess of carbonic acid, nor to bacteria, nor, in most cases, to dusts of any kind. The two great eauses of such discomfort, though not the only ones, are excessive temperature and umpleasant odors. Such rooms as those referred to are generally overheated, the bodies of the occupants, and, at night, the usual means of illumination, contributing to this result.

The canse of the mpleasant, musty odor which is perceptible to most persons on passing from the outer air into a crowded, unventilated room is unknown; it may, in part, be due to volatile products of deeomposition contained in the expired air of persons having decayed teeth, foul mouths, or certain disorders of the diges- 
tive apparatus, and it is due, in part, to volatile fotty acols griven ofl with, of produced from, the excretions of the skin, and from alothing soviled with

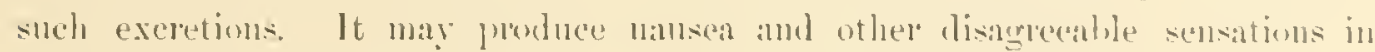
specially smseptible persons, but most men soon become alcoustomeal to it, and

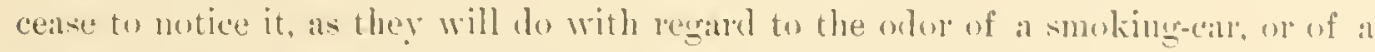
sonp factory, after they hare heren for some time in the flate. 'The direct and

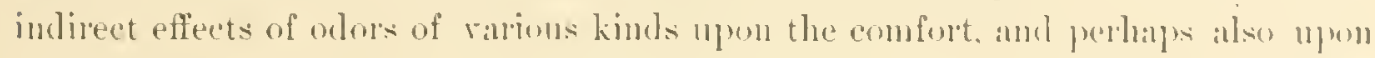
the health, of men are more comsiderable than womld be indicated hy any tests now known for determining the matme and quantity of the matters whoh grive rise to them. The remarks of Renk (38, P. 174) upon this puint merit considelation.

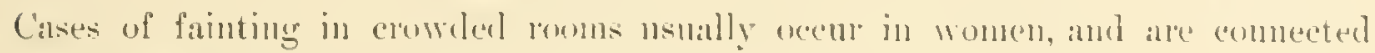
with defective respinatory action due to tight lacing or otleer canses.

Other canses of discomfort in romms heated by funtees on by stean ane excessive dryness of the air, and the presence of small ynantities of cambonic oxide, of illuminating gass, or of alsenic deriverl from the coal used for heating.

XI. 'The results of this investigation, taken in eomection with the results of other recent researehes smmmarized in this report, indicate that some of the theories "yon which moldon systems of ventilation are based ane either withont foumbation or douleful, and that the problem of securing comfort and health in inhabited rooms requines the consieleration of the best methods of preventing or disposing of

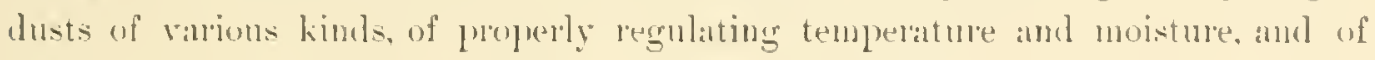
preventing the entrance of poisonous gases like carbonic oxide derived from heat. ing and lighting alplaratus, rather than 11 pon simply diluting the air to a certain standard of proportion of carbonic acid present.

It would be vely mwise to conclude, from the facts given in this repont, that the stambarls of air supply for the ventilation of inhabited rooms, which standards are now generally accejted hy santatrians as the result of the work of l'ettenkofer. J) Chammont, and others, are mud too lange under any circumstances, or that the differences in health and vigor between those who spend the greater part of their lives in the open air of the comntry hills, and those who live in the city shms, to not depend in any way upun the differences between the atmospheres of the tro localities except as regards the number and chancter of nicro-olganisms. 



\section{BIBLIOGRAPHY.}

I. General report of the commission appointed for improving the sanitary condition of Barracks and Hospitals. Fol., London, is6r.

2. Leblanc (F.) Recherches sur la composi. tion de l'air confiné. Ann. d. chin. et. phys., Par., $19+2, V, 223-268$.

3. Regnault ( $\mathrm{V}^{\mathrm{T}}$ ) and Reisset (J.) Recherches chimiques sur la respiration des animaux des diverses classes. Ann. de chim. et phys., Par., 18+9, 3. s., XXV1, 299-519, 2 pl.

4. Friedländer (C.) and Herter (E.) Ueber die Wrirkung des Sauerstoffmangels auf den thierischen Organismus. Ztschr. f. physiol. Chem., Strassb., I879, III, I9-53.

5. Rernard (C.) Leçons sur les effets de substance toxiques et médicamenteuses. Sro, Paris, 1857 .

6. Valentin (G.) Ueber Athmen in geschlossenen Raume. Zischr. f. rat. Med., I.eipz. and Heidelb., 186 1, 3. s., X, 33-100.

7. Bert (P.) Leçons sur la physiologie comparée de la respiration; professées au museum d'histoire naturelle. $8 \mathrm{ro}$, Paris, 1870.

3. Richardson (B. W.) On certain of the phenomena of life. Tr. M. Soc. I,ond., I $\$ 6 \mathbf{I}$, I, 53-1 28 .

9. Pettenkofer (M.) and Voit (C.) Untersuchungen aber die Respiration. Aun. d. chem. 11. pharm., Leipz. u. Heidelb., I $862-3$, 2. suppl. bd., $52-70$.
9. Pettenkofer (M.) Ueber die Respiration. Ann. d. chem. u. pharm., Leipz., u. Heidelb., 1 $862-3,2$. suppl. bd., I -52 .

9. Pettenkofer (MI.) Ueber die Bestimmung des lufförmigen Wassers in Respirations-Apparate. Sitzungsb. d. bayer. Akad. d. Wissensch., II ünchen, 1 $\$ 62$, II, 152-161.

9. Pettenkofer (M.) Ueber die Ausscheidung von Wasserstoffgas bei der Ernihrung des Hundes mit Fleisch und Stärkmehl oder Zucker. Sitzurgsb. d. bayer. Akad. d. Missensch., Münclien, I 862, II, 88-9 I.

Io. Hammond $(11$. A.) A treatise on hygiene with special reference to the military service. svo, Philadelphia, $186_{3}$.

II. Ransome (.1.) On the organic matter of human breath in health and disease. I. Anat, and Physiol., Lond., I870, IV, 209-217, I tab.

12. Smith (R. A.) Air and rain: the beginnings of a chemical climatology. Svo, London, 1872.

13. Seegen (J.) and Nowak (J.) Versuche über die Ausscheidung von gasförmigen Stickstoff aus den im Körper ungesetzten Eiwcissstoffen. Arch. d. ges. Physiol., Bonn., is79, XIX, 347-4I5.

I4. Hermans (J. T. F.) Ueber die vermeintlicle Ausathmung organischer Substanzen durch den Menschen. Fin Beitrag zur Ventilationsfrage. Arch. f. Hyg., Munchen u. Leipz., 1 $S S_{3}$, I, I-40. 
15. Brown-Séquard and d'Arsonval. Démonstration de la puissance toxique des exhalations pulmonaires provenant de l'homme et du chien. Compt. rend. Soc. de liol., Par., is $88_{7}$, S. s., IV, $8 \mathbf{I}^{-8}$ เ 8 .

16. Brown-Séquard and d'Arsonval. Resemblances entre l'action toxique de certaines ptomaines et celle du poison pulmonaire. Compt. rend. Soc. de viol., Par., I888, 8. s., V. Io8110.

17. Brown-Séquard and d'Arsonval. Recherches démonstrant que l’air expiré jar l'homme et les mammifères, à l'éclat de santé, contient un agent toxịue très puissant. Compt. rend. Acad. d. sc., Par., I S88, CVJ, 106-I I 2.

17. Brown-Séquard and d'Arsonval. Nouvelles recherches démonstrant que les poumons sécrètent un poison extrêmement violent qui en sort avec l'air expiré. Compt. rend. Soc. de biol., Par., 1888, 8. s., V, 33-54.

17. Brown-Séquard and d'Arsonval. Sur quelques points importante relatifs à la durée de la survie des lapins apres l'injection sous-cutanée du liquide contenant le poison de l'air expire. Compt. rend. Soc. de biol., Par., I\$SS, S. s., V, 1 21-172.

17. Brown-Séquard and d'Arsonval. Remarques sur la valeur des faits qui nous ont servi à demontrer la toxicité de l'air expiré. Compt. rend. Soc, de biol., Par., ı888, 8. s., V, 99-104.

17. Brown-Séquard and d'Arsonval. Nouvelles remarques à l'égard du poison pulmonaire. Compt. rend. Soc. de biol., Par., 8. s., V, 54-56.

18. Dastre and Joye. Recherches sur la toxicité de l'air expiré. Compt. rend. Soc. de biol., Par., 1 888 , 8. s., V, 91 -99.

19. Russo-Giliberti (A.) and Alessi (G.) Sulla tossicità dell' aria aspirata. Boll. Soc. d'ig. di Palermo, I 888, III, 33 I-340.
20. Wiürtz (R.) Sur la présence des bases volatiles dans le sang et dans l'air expirć. Compt. rend. Acad. d. sc., Par., 1888 , CVI, 213

21. Brown-Séquard and d'Arsonval. Nouvelles recherches démonstrant que la toxicité de l'air expiré ne dépend pas de l'acide carbonique. Compt. rend. Acad. d. sc., Par., 1889, CVIII, $267-272$.

22. Brown-Sécjuard and d'Arsonval. Description d'un appareil permittant de faire respirer a plusieurs animaux de l'air libre et sur quant à ses proportions d'oxygène et d'acide carbonique, mais contenant des quantités considérables du poison de l'aire expiré. Compt. rend. Soc. de biol., Par., I 888 , 8. s., V, I 10.

23. von Hofmann-Wellenhof (G.) Enthält die Expirationsluft gesunder Menschen ein flichtiges Gift? Wien. klin. Wochnschr., 1888 , I, 753-755

24. Uffelmann (J.) Luftuntersuchen, ausgeführt im hygienischen Institut der Universität Rostock. Arch. f. Hyg., München u. Leipz, I 888 , V]II, 262-350.

25. Lehmann (K. B.) and Jessen (F.) Ueber die Giftigkeit der Expirationsluft. Arch. f.

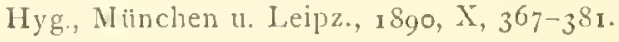

26. Lipari (G.) and Crisafulli (G.) Richerche sperementali sull' aria espirata dall' uomo allo stato normale. Sicilia med., Palermo, I889. I, 229. Also, transl. [Abstr.]: Arch. de physiol. norm. et path., Par., $1890,5$. s., II, 679.

27. Nargouty (B. M. E.) Du rôle des matières animales dans la nocivité de l'air expiré. fto, Bordeaux, $189 \mathrm{I}$.

28. Haldane (J.) and Smith (J. I..) The physiological effects of air vitiated by respiration. J. Path. and Bacteriol., Edinb. and Lond., I $892-3$, J, I 68- I 86 .

29. Merkel (S.) Neue untersuchungen über die Giftigkeit der Expirationsluft. Arch. f. Hyg., München u. Leipz., I $892, X V, I-28$. 
30. Haldane (J.) and Snith (J. I..) "The toxic action of expired air. I. Path. and liacteriol., Edinb. and I.ond., 1S92-3, 1, 318-321.

31. Ben (I.) Untersuchungen ïber die Giftigkeit der Expirationsluft. Sro, Rostock, 1893. .11so in Ztschr. f. Hyg., 1.cipz., 1893 . XIV, 6.7-75.

32. Rauer. Untersuchungen über die Girtigkeit der Fixpirationsluft. Ztschr.f. Iyg., Leipz., $1893 . \mathbb{X V}^{*}, 57-71$.

33. Sanfelice (F.) Sull' aria di alcune ambienti abitali. Ann. d. Ist. d'ig. Sper. d. R. Univ. di Koma, $1893, n$ s., II], 399-436.

34. Lubbert (A.) and Peters (R.) Ueber die Giftwirkung der Ausathmungsluft. Pharm. Centralhalle, Dresd., ISo4, $54 \mathrm{t}-5+8$. Also, [. Ibstr.]: Hyg. Rundschau, Berl., IS94, IV, I I 8 .

35. Brown-Séquard and d'Arsonval. Nouvelles recherches démonstrant que la toxicite de l'air expiré dépend d'une poison provenant des pounons ct non de l'acide carbonique. Arch. de physs. norm. et. path., Par., 1894.5 . s.. XVI, $113-124$.

$3^{6 .}$ Ibbott (A.C.) Chemical, physical, and hacteriological studies upon air over decomposing substances, with special reference to their application to the air of sewers. Tr. Cong. Am. Phys, and Surg., New Haven, 1894, III, 28-6z.
37. Birkholz (W'.) Ueber den liinfluss der Temperatur und der Ernïhrung auf ihr Kohl. ensäurepruduktion in Thierkörper. Inaug. diss. 8vo, Erlangen, 1889 .

38. Renk (F.) Die Luft. Handb. d. Iyg,, Sto, Leipz., 1886, 1. "Th. 2. Abth. 2 Ilft., 1-242.

39. Kemsen (1.) Report on the subject of organic matter in the air. Bull. Nat. lid. Health, Wash., 18So-1, 517-521.

40. Talbot (MI.) Technol. Quarterly, 1887 , 1. 29 .

41. Nékám (I. 1.) Ueber die Untersuchungen der organischen Substanzen der Luft. Arch. f. Hyg., Mïnchen w. I.eipz., 1890, XI, 396-409.

42. Archarow (J.) Ueber die Bestimmung der organischen Stoffe der luft vermittelst Kaliumpermanganat. Arch. f. Hyg., München u. Leipz., 1S91, XIII, 229-246.

43. Carnelly (I') and Mackie (IV.) l'he determination of organic matter in air. I'roc. Roy. Soc., I.ond. (18S6), I $88_{7}$, XI.I, $23^{8-247}$

44. Friedländer (C.) and Herter (E.) Ueber die Wirkung der Kohlensäure anf den thierischen Organismus. Ztschr. f. physiol. Chem., Strassb., I878-9, II, $99^{-1} 4^{8}$. 


\section{APPENDIX.}

DETAILS OF METHODS EMPIOYED, ANI) RESULTS OBTANED, IN FXPIRIMENTS CPUA THE H.FECTS OF EXPIRED AIR.

BY

DaVid HeNtRICKS BergeY, B.S., M. D.

(The numbers in parentheses refer to the bibliographical list appended to the report.)

I. - Four experiments were made to deternine whether the air expired by man contains microorganisms. The results are shown in the following table.

\section{TALLE A.}

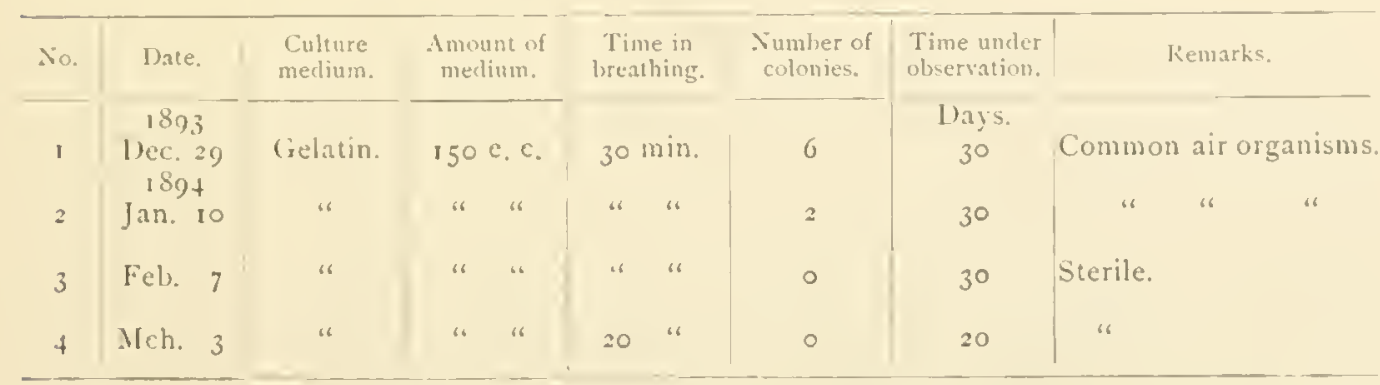

In these experiments the expired breath was conducted through melted gelatin contained in the apparatus slown in ligg. 1 , for 20 to 30 minutes. The gelatin was then hardened by rolling the flask in a shallow basin containing ice-water, thus distributing the culture in a thin layer over the bottom 
and sides of the flask. These cultures were kejt under observation for 20 to 30 days. About r5o

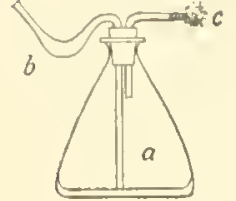

Fig. I. - Ipparatus for determining the pressure of bacteria in expired breath. c. c. of the gelatin was used for each experiment. The glass tube, $b$, of the apparatus used, which served for the contrance of the expired air, was inserted far enough to just impinge on the fluibl culture medium in the flask, so that the air producel a slight agitation of the fluid in passing through the apparatus.

lescription of the apparatus used for determining the presence of bacteria in expired breath, lig. 1.: a, represents a half litre Erlenmeyer flask closed with a rubber stopper having two openings. Each of these openings is closed by a glass tube bent at right angles above the stopper.

b. represents the longer glass tube which reaches nearly to the bottom of the flask. This tube has a small bulb-shaped enlargement blown into its upper end, which serves to retain any saliva that might flow into the tube. This tube serves as the mouthpiece through which the air enters the apparatus. When not in use, the mouth-piece is closed with a small cotton plug. The internal diameter of the tube is seven mm.

$c$, the shorter tube is bent at right angles and terminates just below the stopper. The external end of this tube is closed with a cotton plug to prevent the entrance of micro-organisms from this side of the apparatus. The internal diameter of this tube is also seven mm.

The organisms which developed in these cultures were all of the same character-a small yellow bacillus which is quite common in the air of the laboratory. In the experiments in which gelatin remained sterile, the jrecaution had been taken to sterilize the apparatus with dry heat for an hour previous to introducing the gelatin, besides the subseguent sterilization of the culture medium on three successive days. If, after standing in the working room for several days, it was found that the culture medium was sterile, the expired breath was then conducted through the apparatus and the culture was kept under observation (for the time specified in the table) at the room temperature. The nature of the organisms that developed in the first two experiments, and the absence of any growth in the others, makes it probable that they developed from spores that survived the fractional sterilization of the culture medium. It is improbable that they were carried in the expired breath.

Several attempts were made to use bouillon and litmus milk instead of gelatin, as the culture medium. Neither of the former media was found to be suitable for the purpose.

Careful examination of the Huid condensed from the expired air was made with high powers, both in hanging drops, and in six dried and stained preparations, but nothing resembling bacteria or epithelium was found. A few amorphous particles, a few ninute apparently crystalline masses, and here and there a fragment resembling vegetable fibre, were all that could be seen.

I1. - I series of experiments was made to determine the amount of ammonia, of albuminoid ammonia, and of oxidizable matters contained in the fluids condensed from expired air.

The apparatus used in collecting the condensed vapor from expired breath is represented in Fig. 2, the condenser of which is laid in ice. Each time before this apparatus was brought into use, the condenser was boiled out with either a solution of bichromate of potash and sulphuric acid, or with alkaline permanganate of potash, then freely rinsed with twice distilled water until entirely free from the cleansing solutions used. The apparatus was then quickly connected together and placed in a large steam sterilizer for an hour. The condenser was then packed in ice and the breath exhaled through the apparatus, using but little greater expiratory force than in ordinary respiration. In several of the experiments a gas meter was attached after the alparatus, in order to measure the volume of air exhaled. This was found to approximate a third of a cubic metre per hour, during which time as nuch as 12 c. c. of moisture was collected.

The amount of air expired in ordinary quiet respiration ranges from foo to 500 litres per hour. It is evident that the diminished amount exhaled in the experiment did not represent the full respiratory capacity; the reduction observed having its cause, in all probability, in the slightly greater effort reguired to conduct the expired breath through the apparatus. It was noted that the number of expirations ranged from twelve to fifteen per minute, the ordinary rate being about 
eighteen per minute. This was also caused by the slight obstruction to the respiratory current prolonging the expiratory movement. Inhalation took place through the nose.

\section{DESCRIPTION OF FIGLRE: 2 .}

This apparatus was used to condense moisture from the expired breath. It consists of a glass mouth-piece, as having an internal diameter of seven millimetres; its length being twenty centimetres. The distal end of this tube is leent at an olutuse angle and is connected with a glass tube of similar size, bent at right angles, and inserted through one of the openings of the rubber stopper of the wicle-mouthed flask b. The other opening of this stopper carries a similar glass tube, also bent at right angles, attached to the proximal arm of the condenser $i$. To the distal arm of the condenser is attached another glass tube, also bent at right angles, passing through one of the openungs of the rubber stopper of the wide-mouthed flask $c$. The other opening in this stopper carries a glass tube of similar size, also bent at right angles, passing nearly to the bottom of the Rask. The different parts of the apparatus are connected together ly means of short pieces of stout, closely fitting rubber tul,ing. The small wicle-mouthed flask b serves as a receptacle for saliva. The tubing in the stopper closing its mouth terminates just below its inner surface. The condenser $c$ is $l^{*}$-shaped, with each of its arms bent at right angles about half-way down to the lower dilated portion. and has an internal diameter of seven millimetres. The dilated portion of the condenser is twelve centimetres in length and four centimetres in its external diameter. The small wide-mouthed hask $c$ is nearly filled with small, pea-sized pieces of pumice-stone saturated with concentrated suphuric acid. This serves to arrest the organic matter in any air that might accidentally enter from this side of the apparatus. The U-shaped condenser rests in a square glass dish $d, 20 \times 8 \times 8$ centimetres in its external dimensions, containing cracked ice.

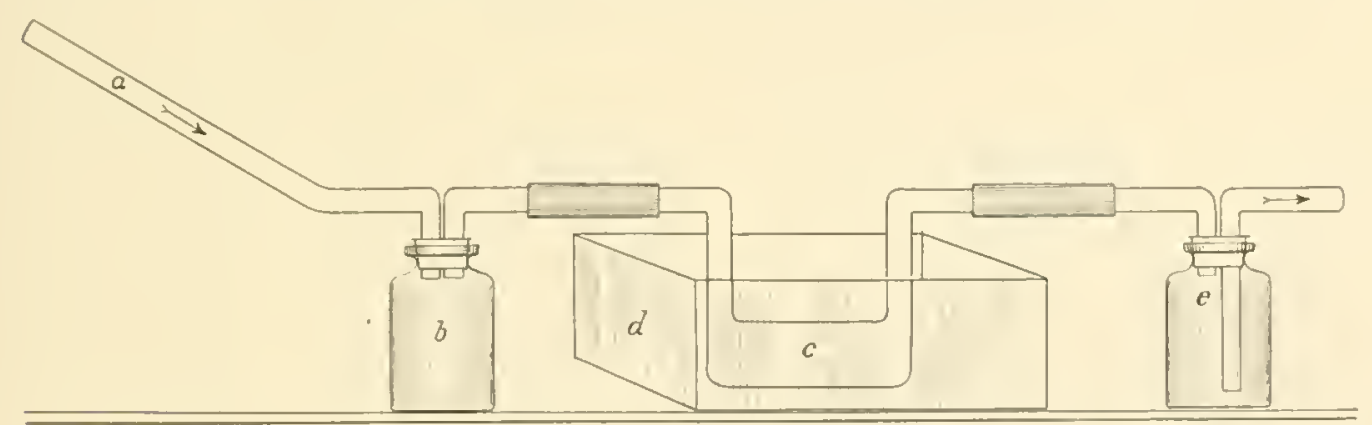

Fir, 2.-Apparatus to condense moisture from the expiref breath.

In order to adapt the mouth-piece of this apparatus to the fistulous opening in the throat of the man that had had his larynx removed, the proximal end of the mouth-piece was attacled to a porcelain mouth-piece used for speaking-tubes. This was padded with several layers of cheese cloth, and the loose encl of this tied around his neck to hold it in position. In this manner be was able to exhale through the apparatus without any difficulty.

Some of the condensed flud was collected from my own breath and that of other healthy persons; other portions were collected from a man having a permanent fistulous opening in his throat through which he breathed; there being no connection whatever with the mouth and upper air passages. Some flud was also collected from the breath of a man suffering from advanced tubercular disease of the lungs.

The amount of free and alluminoid anmonia in this condensed nuid, as estmated according to the well-known method of Wanklyn. Clapman, and Smith, is shown in Table li, together with the amount of fluid used in earh of these determinations and the time required in collect these portions of fluid. A definite portion of the lluid was diluted with $500 \mathrm{c}$. c. of twice distilled water, 
and the ammonia in a like quantity of the same water was determined simultaneously and deducted from the amount found in the diluted fluid. The minute quantities of ammonia found in the fluid in some of these determinations required the greatest care in manipulation to avoid all sources of contamination-in the collection of the fuid as well as subsequently in the distillation and nesslerization. 'The greatest care had to be excrcised, therefore, in cleansing all apparatus used, and in the preparation of the different reagents.

The luid for the first seven determinations was collected from my own breath, and, for the next thirteen determinations, from the breath of the man with the tracheal fistula. The remainder of the determinations were made on the fuids collected from the breath of the consumptive.

Table B.

DETERMINATION OF FREE AND ALEUMINOID AMMONIA IN CONDLNSÉ FlUID OF RESPIRATION.

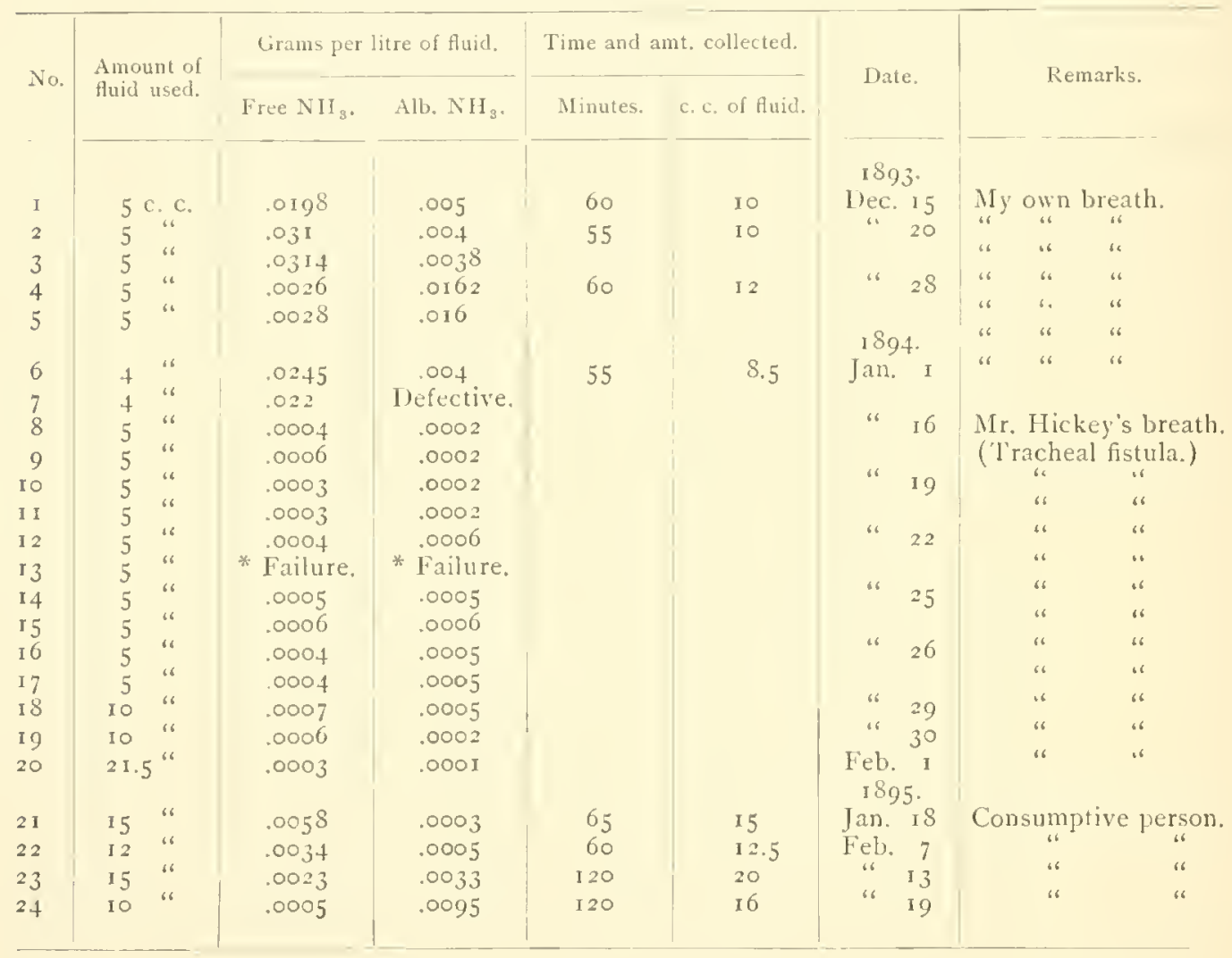

The amount of organic matters present in the condensed fluid, as shown by its reducing power upon solution of permanganate of potash, is represented in Table $\mathrm{C}$, the results being calculated to $\mathrm{Mg}$. of O. consumed to one litre of the condensed fluid. The table also shows the amount of fluid used in each of the determinations and the time reguired to collect such amount. In three of the experiments the amount of air expired is also given. These determinations were made according to the methods now in common use for the determination of organic matter in water as modified by Kubel; the tluid being diluted with a definite amount of distilled water, the reducing power on permanganate of which was simultaneously determined and deduced from the results obtained. The ebullition of the fluid was always carefully timed-the time being five minutes.

* Merely a trace found. 
TABLE C.

DETFRAISATION OF OSIDIZABIA MATTER IS COSDFSSED MOISTLRE OF RISPIRATIOX

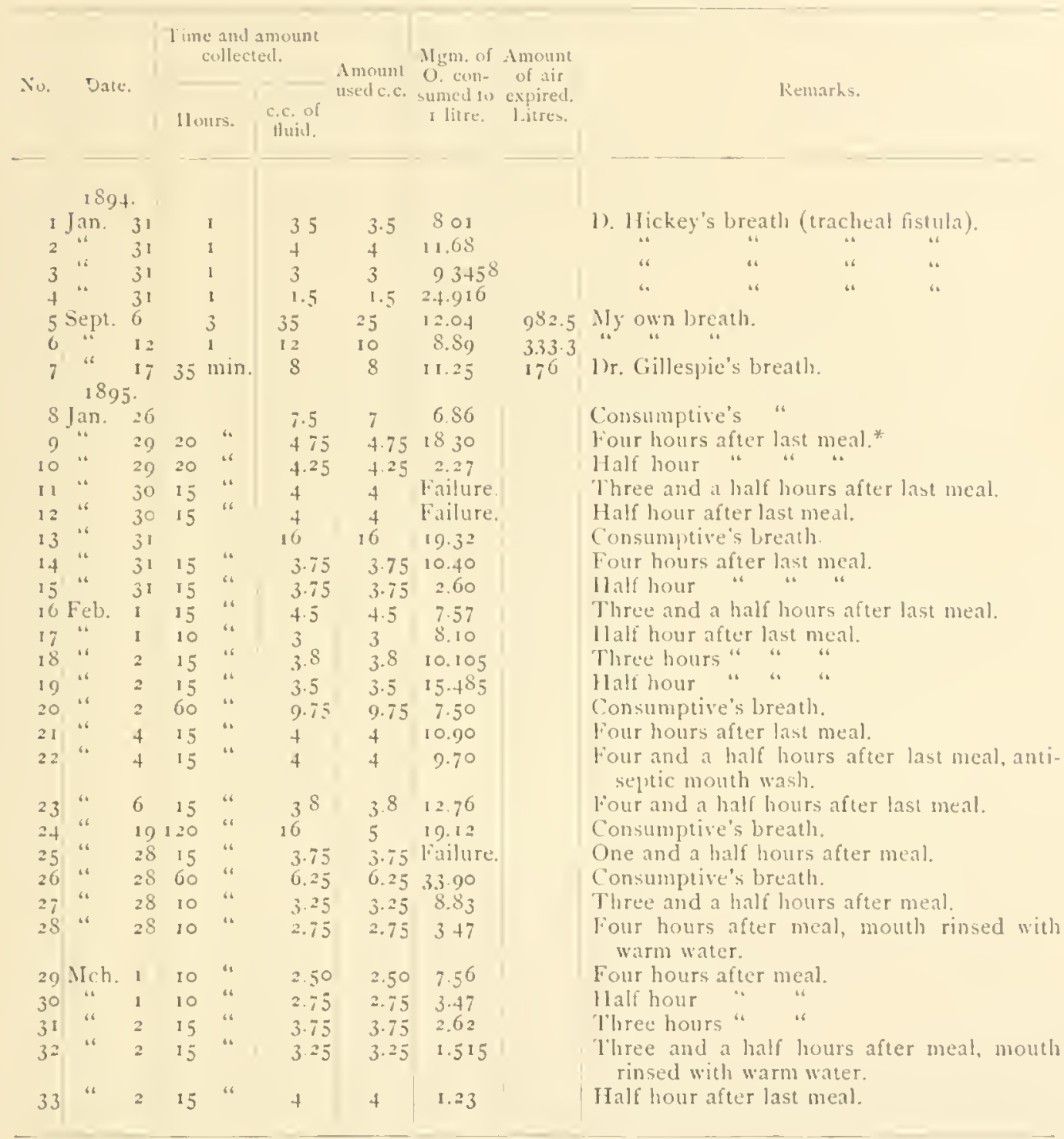

lhe fuids for these determinations were eollected from the breath of the man with the tracheal fistula; from the breatl of the consunptive; and from my own breath and that of another healthy person. With the exception of one of the results obtained with flud collected from the breath of the man with the tracheal fistula, which result is out of accord with the others (cause unknown), the determinations show no marked variation in the amount of oxidizable matter. what. wer the source of the lunid or conditions of the person from whose breath it was collected, though only a few experiments were made. Just before collecting the Huid for several of the later deter-

* The fuids for the determinations before and after meals were collected from my own breath. 
minations in the table, the mouth was well rinsed in a weak solution of formalin or with warm water. A reduction of $1.2 \mathrm{Mg}$. of 0 . per litre in the azd from the amount required for the fuid collected the half an hour before, seems to have resulted fom the use of the antisejutic nouth wash, in others a still greater reduction was brought about by simply rinsing the mouth several times with warm water.

Several efforts were made to obtain evilence as to the chemical nature of the condensed fluid collected from my own breath. Eighty (80) litres of expired air were conducted through $50 \mathrm{c}$. c. of a one per cent. solution of oxalic acid in ten minutes. This fluid gave a decided yellowish-brown color with 1. c. c. of Nessler's reagent, showing at least five times as much ammonia as was present in the distilled water used to make the oxalic acid solution. The fluid condensed from exhaled breath, obtained by conducting the breath through a condensing apparatus laid in ice, was tested with the following reagents for the presence of a volatile organic alkaloid: $\mathrm{AuCl} \mathrm{Cl}_{3} \mathrm{PtCl}_{4}$, Ammon. Molybdate,. $\mathrm{g} \mathrm{N(I_{3 }}$; reaction negative. Nessler's reagent produced a yellow color, and a few drops of a 10 per cent. solution of $\mathrm{HgCl}_{2}$ with a few drops of a 10 per cent. solution of bi also gave a yellow color.

The results of the tests, though few in number, give no evidence of the presence of expiratory products other than those indicated by the determinations of ammonia, and the reducing power on solution of permanganate of potash.

III.-Experiments with fluid condensed from the air of a large surgical ward in the University

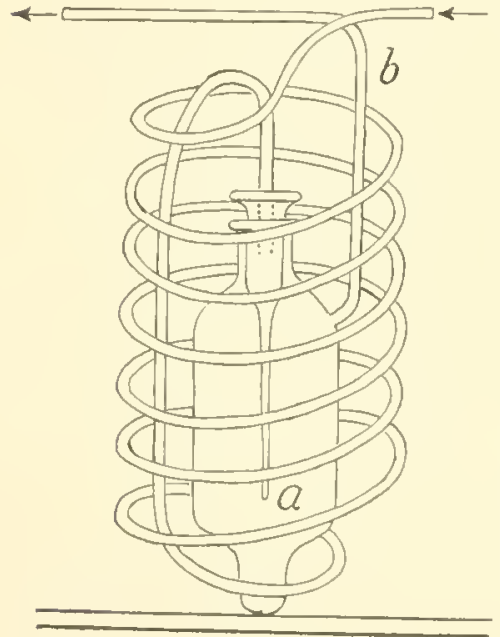

Fic. 3.- Comflenset of apparatus shown in Figr. $+(X 5$. Hospital, with and without filtration of the air.

Several efforts were made to collect moisture from the air of a crowded surgical ward of the Hospital by means of a large glass funnel, sealed at the neck and filled with ice. A small beaker was placed beneath the funnel to collect any moisture condensing on its exterior. This method proved unsuccessiul, and was abandoned. An apparatus, shown in Fig. 3, and arranged as shown in Fig. 4, was placed on a mantel over an unused open fire-place at one end of the ward.

Description of the apparatus used to condense the moisture in the air of the hospital ward:

Fig. 3 represents the condenser, consisting of $a$, a small glass receptacle eleven centimetres in height and three centimetres in diameter at its widest part, and having a capacity of $50 \mathrm{c} . \mathrm{c}$. 'l'his receptacle has two openings, the one at the top being closed with a closely fitting, hollow, glass stopper; the second opening consists of a glass tube coming obliquely from the expanded portion near the top, and at a distance of three centimetres bends upward along the side of the receptacle. This serves as the exit tube to the receptacle, while the air enters through the hollow glass stopper closing the other opening. Each of the tubes has an internal dianeter of four millimetres. The spiral portion of the condenser consists of a piece of block-tin tubing, $b$, three metres in length, and five millimetres in internal diameter. This is connected with the entrance tube of the receptacle by means of a short piece of rubber tubing, and with the dust filter by a longer piece of rubber tubing. The exit tube of the receptacle has a piece of glass tubing, thirty centimetres in length, and five centimetres in internal diameter, fused to its end. This is bent at right angles near its upper extremity, and connected with the gas meter by means of a piece of rubber tubing.

Fig. 4, represents the apparatus as arranged in the hospital ward. a represents an inverted bell-jar with the condenser packed in ice. The bell-jar is supported by an iron tripod, $b$. The dust filter, consisting of a glass tube loosely packed with asbestos, is represented at $c$, and is attached to a stative by means of a clamp, while $e$ represents the gas meter, and $f$ the water faucet in the lavatory. The meter is connected with the faucet by means of a long piece of block- 
tin tubing of 1 centimetres internal diameter. $g$ represents the (hapman water pumpattached to the faucet.

The dust filter, $c$, is twenty eentimetres in length, consisting of a narrow portion four centimetres long and three millimetres in internal diameter, and of a wider portion sixteen centimetres long and twelve millimetres in internal diameter.

The condenser was cleansecl ly rinsing it with a solution of bichromate of potash and sulphuric acid, then removing all trace of this solution by rinsing it repeatedly with twice distilled water. The cleansing of the apparatus was greatly iacilitated by attaching it to a (hapman water pump in the laboratory, and drawing the cleansing solution and distilled water through it in large quantities. It was then placed in the insered bell jar, packed in ice, and connected with the meter and pump in the hospital ward.
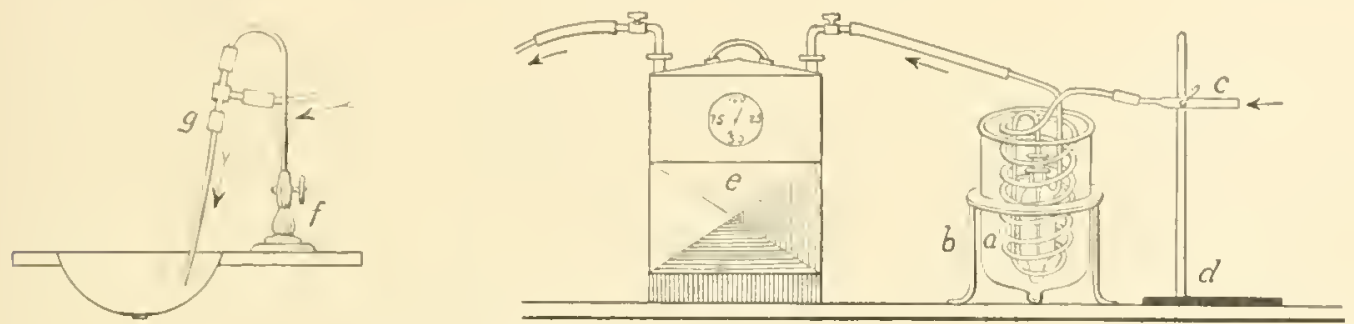

Fi:, 4.- Ipparatus ued to conclense moisture from the air of the Ilospital Wiarl.

With this apparatus a small amount of fluid was collected on days when the atmosphere was saturated with moisture, but if this fuid was allowed to remain in the receptacle during several days of clear weather it slowly evaporated. Ilowever, enough fluid was collected in this manner to make several determinations of the free and albuminoid ammonia in it. The results thus obtained are shown in Table I): the first and shird experiments showing results obtained withont placing a dust filter of asbestos before the condenser. The second and fourth experiments show the results obtained bỵ attaching such a dust filter.

THLE D.

IETERMINATION OF FREE ANI AIBCMUNOID AMMONIA IN THE MOISTLRE CONDFNGED FROM THF. AIR OF THE UOSPIIAI. WARD.

\begin{tabular}{|c|c|c|c|c|c|c|c|c|}
\hline \multirow{2}{*}{ No. } & \multirow{2}{*}{ Date. } & \multirow{2}{*}{ l'ime. } & \multirow{2}{*}{$\begin{array}{l}\text { l.itres of air } \\
\text { aspirated. }\end{array}$} & \multirow{2}{*}{$\begin{array}{l}\text { Imt, of moisture } \\
\text { condensed. }\end{array}$} & \multicolumn{2}{|c|}{ 'Grms. per $1000 \mathrm{cbm}$. air. } & \multirow{2}{*}{$\begin{array}{l}\text { No. of } \\
\text { bacteria per } \\
\text { c. c. of thid. }\end{array}$} & \multirow{2}{*}{ Remarks. } \\
\hline & & & & & Free $\mathrm{NH}_{3}$. & Alb. $\mathrm{NIH}_{3}$ & & \\
\hline 1 & 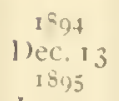 & $\begin{array}{c}\text { Hours. } \\
+3 !\end{array}$ & 4612.9 & 3. c. c. & 0.0210 & 0.0028 & 3140 & No dust filter. \\
\hline 2 & Jan. 9 & $41 \frac{1}{2}$ & 39903 & 7. & 0.00075 & 0.00125 & 1331 & Dust filter. \\
\hline 3 & "T 8 & $3+1$ & 1669.7 & 3. " & 0.0012 & 0.0015 & & Nodust filter. \\
\hline 4 & Mch. 4 & 33 & 1980.0 & $2.6 " 6$ & 0.0015 & 0.0010 & & Dust filter. \\
\hline
\end{tabular}

Mieroscopic examination of the Auid condensed from the air of the hospital ward slowed : a number of small amorphous particles-black, yellow, and colorless : a few small crystals, a few epithelial seales, small bits of vegetable fibre, and a few bacteria.

(ultures made from this thid showed numerous colonies of moulds, numerous common air and water organisms, some of which rapidly liquefied the gelatin of the eultures. 13, pyocyanus was found in one instance, in others a yellow sarcina, and yeasts of different colors. Besices ihese a 
bacillus belonging, apparcutly, to the $\mathrm{B}$. coligroup was found in most of the cultures; in one iustance this bacillus was present in very large numbers and excluded nearly all the other forms. It was also noted in the gelatin plates exposed in the ward, and in the cultures from dust collected near the apparatus.

On several ocrasions the dust which had collected on the meter and mantel during the night was taken up on a sterilized cotton swab and inoculated npon gelatin plates. The cultures in these plates did not differ greatly from those made from the fluid, except that the moulds were present in larger propurtion than the other organisms noted in the cultures from the fluid.

Gelatin plates exposed to the air of the ward showed the same character of organisms as in the cultures from the condensed fluid and those which developed from the dust collected in the vicinity of the apparatus. In addition to the species already noted, colonies of staphylococcus anrens and albus were also noted in these plates.

The small amount of fluid collected irom the air of the hospital ward in the manner stated, and the rapidity with whirh it evaporated on clear days, made it impossible to collect a sufficient quantity to inoculate it into animals. To overcome this difficulty a small quantity of sterilized glycerine ( 7.5 to ro c. c.) was aspirated through the condensers after it had been cleansed. It is doubtful, however, whether this served to withdraw an appreciable amount of moisture from the air. After aspirating air through the apparatus for several days it was brought to the laboratory and the fluid in the receptacle transferred to a small sterilized flask. The condenser was then washed out by aspirating 8 to $10 \mathrm{c}$. c. of twice distilled water (sterilized) through it. This was added to the fluid poured from the receptacle, thoroughly mixed with it, and inoculated into animals. The glycerine in this fluid inoculated into the animals was diluted at least 50 per cent. Three sets of animals were inoculated and each time a control animal was inoculated with equal parts of glycerine and distilled water that had been sterilized for one lour. 'The results of these experiments are shown in Table E.

\section{TABLE E.}

COLIECTION OF BACTERIA, ETC., FROM THE ATMOSPHFRE OF THE HOSPITAL WARD, USING GLYCERINE IN THE ABSORPTION APPARATUS.

\begin{tabular}{|c|c|c|c|c|c|c|c|c|c|c|c|}
\hline \multirow{2}{*}{ No. } & \multirow{2}{*}{ Date } & \multirow{2}{*}{ Tine. } & \multirow{2}{*}{$\begin{array}{l}\text { Litres of air } \\
\text { dspirated. }\end{array}$} & \multirow{2}{*}{$\begin{array}{l}\text { Amt of } \\
\text { glycerine } \\
\text { used. }\end{array}$} & \multicolumn{6}{|c|}{ Weight of rabbit and amt. of fluid injected. } & \multirow{2}{*}{$\begin{array}{l}\text { To. of bacteria } \\
\text { in dilute fluid, } \\
\text { per c. c. }\end{array}$} \\
\hline & & & & & Weight. & c. c. & Weight. & c.c. & $\begin{array}{l}\text { Weight, } \\
\text { (control } \\
\text { animal.) } \\
\end{array}$ & c.c. & \\
\hline & 1894 & Hours. & & & Grams. & & Grams. & & Grams. & & \\
\hline I & Dec. 5 & $47 \frac{1}{2}$ & I $3333^{8.8}$ & IO C. C. & & & & & & & 900 \\
\hline 2 & I 895. & $69 \frac{1}{2}$ & & $10 " 4$ & & & & & & & 450 \\
\hline 3 & Jan. 1 & $47 \frac{1}{2}$ & 7754.2 & $7 \cdot 5^{\prime \prime}$ & 3050 & 16 & $1 \mathrm{~J} 30$ & 2 & 1025 & 2 & 2675 \\
\hline 4 & "6 3 & $44 \frac{3}{4}$ & 7669.3 & $7 \cdot 5^{\prime \prime}$ & 2205 & 6 & 2350 & 6 & 2205 & 6 & 1893 \\
\hline 5 & " 5 & $52 \frac{1}{2}$ & $492+2$ & $7 \cdot 5^{\prime \prime}$ & 1970 & 6 & I 280 & 6 & 1400 & 6 & 1646 \\
\hline
\end{tabular}

The animals inoculated with the products collected from the air of the hospital ward in the manner stated were under observation for two months. Three of these animals died during the time they were under observation. The control animal of the third series died after twelve days. This animal was observed to be in poor health for several days before its death. On examination, post mortem, it was found to have had a good-sized abscess in the right axillary fossa, which had ruptured externally: The liver presented numerous whitish bands and foci on all of its surfaces and throughout the matrix. A number of echinococcus cysts were found adherent to the liver, spleen, and the omentum. The kidneys were normal in size and appearance, and the capsule was easily removed. The other organs appeared normal.

Cultures were taken from the abscess, blood, lungs, liver, spleen, and kidneys. Those from the site of the abscess were the only ones developing any growth. The prevailing organisms in the cultures from the abscess were staphylococcus albus and aureus. 
Cover-stip preparations were mate from the abscess, blood, lungs, liver, splecn, and kidney. Those from the site of the absess were the only ones showing any organisms; numerous cocci, with a few bacilli, were observed.

Microscopic examination of the organs hardened in alcohol and mounted in relloirlin: The liver presental some increase of ronnective-tissue elements between the lobules fhe whitish bandi on the surface of the organ, noted at the atopsy, were found to be due to this increase in connective-tissue elements in the inter-lobular spaces. No change was noticed in the libercelis themselves. 111 the other organs were found to be normal.

The nature of the substances inoculated into this control amimal $(6 \mathrm{c}$. c, of equal parts of sterilized glicerine and distilled water) and the antiseptic precautions observed in the inoculation make it cluabtful whether the source of infection is traceable to the experiment. The changes noted in the liver are of such a nature as on indicate their production by causes preceling even those which brotght about the death of the animat.

Ralutit No. 2 of the first series, having received $2 \mathrm{c.c}$. of the fluid obtained by aspirating the air of the hospital ward through the condensing apparatus moistened with sterilized glycerine, died after 35 days. Autopisy: 11 alf-grown rablit, poorly nourished, and adipose all used up, presented nothing important externally. Jnternally: A small amount of clear fluid in the alulominal cavity; the liver is somewhat darker than normal, motted, and contains a few jusorosperms. Spleen is normat. Kielneys and adrenals are normal in appearance. The right lung is considerablv congested, being readily torn; the left is also slightly congested. The right side of the heart is filled with dark fluid blood: the lefo side is nearly empty. Sereral echinococcus cysts were found in the abdominal cavity.

Cover-slip preparations were made from the abdominal fluid, the kidneys, liver, spleen, lung, and bloot ; all proved negative.

The organs were preserved in alcohol and mounted in eelloidin for microscopic examination.

Microscopic examination of the organs: I.eft lung showed the capillaries and larger vessets very much dilated and filled with blood. Infiltration of letcocytes was noted here and there. Right bung showed marked proliferation of cells and infileration of leucocytes. Many of the air cells were obliterated. The liver, kidneys, and spleen were normal.

Rabbit No. I of the second series, inoculated with the fuid obtained from the air of the hospital wart, diet after 38 days. Autopsy: Full-grown rabbit, shows numerous bruises and lacerations of the skin over various parts of the body. Many of the wounds along the sicles and back show ecchymoses under the skin. Adipose not all used up. Internally : I.jer stightly darker and somewhat larger, apparently, than normal. Spleen is larger than normal. Kidneys embedded in fat, normal in appenrance. I,ungs and heart normal. Blood is dark and fuid.

Cover-stips were male from all the organs with negative results.

The organs were preserved in alcohol and mounted in celloidin for microscopic examination.

Microscopic examination of the organs: No abnormalities could be found in any of the organs: all appearing to be normal.

The remaining rabbits of these series showed no symptoms of any deleterious influence from the fluid inoculated. No swelling or formation of abscess was noted in any of them.

Rabluit No. 2 of the first series evidently died of lung disease, as shown at fost mortem. As in the causation of this disease, it is impossible to venture an opinion. Rabbit No. I of the second series clied of causes which left apparently no manifestations pointing to their nature. ${ }^{*}$ Rabloit No. 3 (control) of the thirel serites es ilently died from the effects of the extensive axiltary abseess. As to the source of the infection, no lecided opinion can be given. I'robalsly the intertion gained an entrance through the inoculation wound.

Some experiments were made to determine the amount of oxidizable matter in atmospineric air. It first a me:tsured amount of air was slowly aspirated through twire distilled water, and the amount of oxidizalile matter extrated from the air estimated according to the method used for determin-

* Death may have resuled from injury, as whown by the contusions and wounds noted at autopsy. These wounds were probably intlicted by other rabbits in the same cage. 
ing the oxidizable matters in the condensed fluid of respiration. In the later experiments the air wis conducted through two tlasks-the first containing 100 c. c. of a 1 per cent. solution of sulphuric acid, the second 100 c. c. of al I per cent. solution of polissium hydroxide. After aspirating a measured amount of air through these solutions, $50 \% c$. of each were mixed together and the amount of oxidizalole matter determined as in the earlier experiments. The results are shown in lable Ii.

T'ADLE I".

DETERMINATIONS OF OXIHZABLE ORGANIC MATTERS IN ATMOSIHERIL AIR.

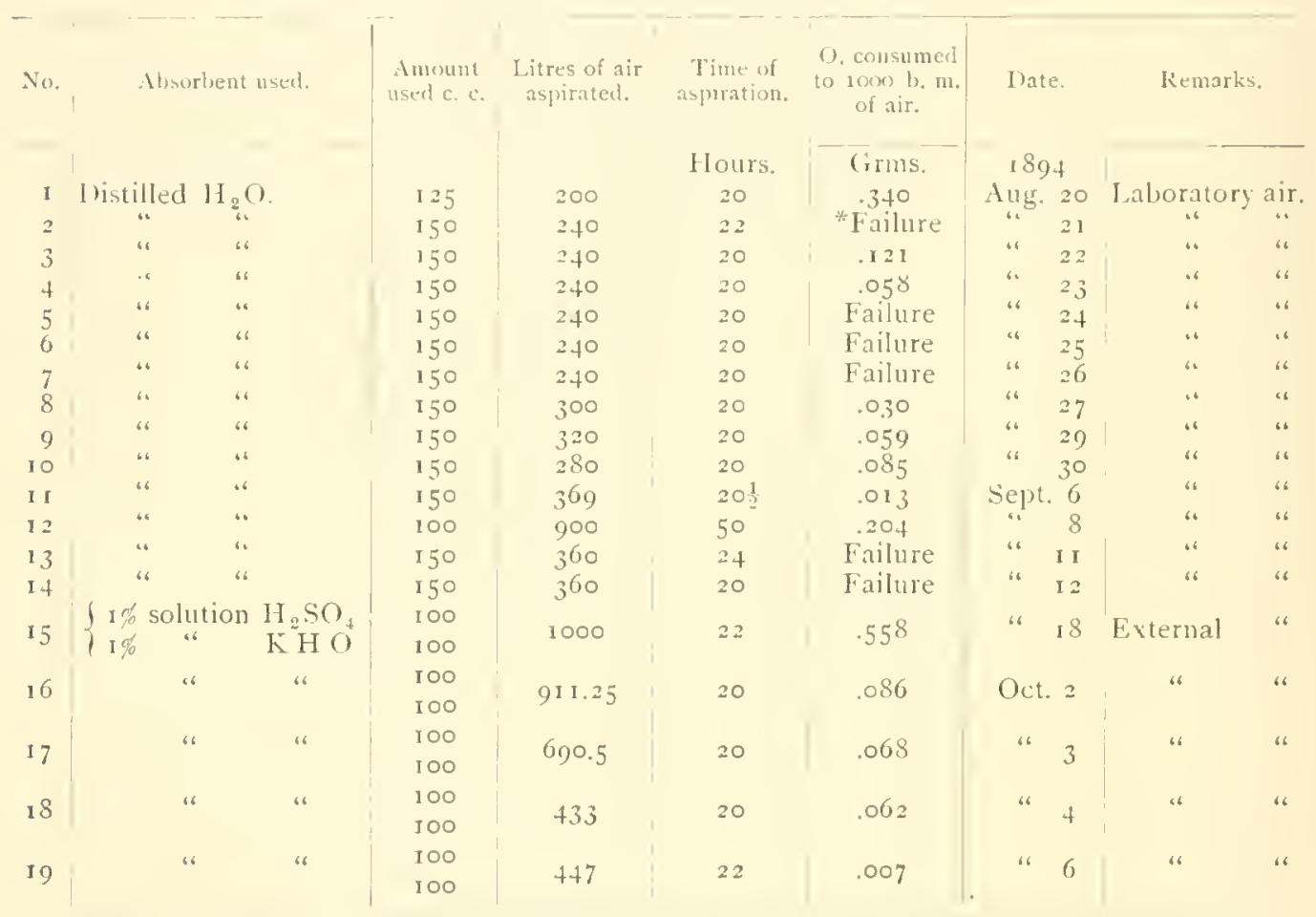

These experiments were made at a season of the year when the windows of the laboratory were open most of the time and the amount of dust floating in the laboratory air must have been about equal to that in the external air. The method employed to obtain the oxidizable matter from the external air is preferable to that employed for the laboratory air, and, since equal portions of the solutions used neutralize each other, they have no objectionable infuence upon the process of determination of the oxidizable matter.

In several instances a portion of the water, containing the oxidizable matter extracted from the air, was treated with $\mathrm{AgNO}_{3}, \mathrm{HgCl}_{2}, \mathrm{AuCl}_{3}, \mathrm{PtCl}_{4}, \mathrm{~K}_{4} \mathrm{FeCy}_{6}, \mathrm{~K}_{6} \mathrm{Fe}_{2} \mathrm{Cy} y_{12}, \mathrm{KHO}, \mathrm{Ba}(\mathrm{HO})_{2}$, $\mathrm{H}_{2} \mathrm{SO}, \mathrm{I}$, and with phosphomolybdic acid, am. molybdate, but no reaction was obtained with any of these, either in hot or cold solution. Nessler's reagent gave a deep yellow color, and $\mathrm{HgCl}_{2}$ with KI produced a lemon-colored precipitate, rapidly changing to red, with deposit of $\mathrm{HgI}_{2}$.

IV.-Experiments on mice and birds confined in glass jars, by the method used by Hammond (10).

The exact conditions under which Hammond conducted his experiment are not given in his treatise, and the size of the jar he used is uncertain. Taking the relative sizes of the animal, jar, and the other parts of the apparatus shown in the accompanying figure, it seems probible that he used a jar of at least four litres' capacity. In the apparatus used for our experiments, two- and four- 
litre jars were used. The arrangements for the absorption of moisture, $\mathrm{CO}_{2}$, and for the introduction of fresh air, were the exact counterparts of these arrangements in Hammond's apparatus, judging from his description and engraving. Fresh air was supplied at intervals of one-half to one hour. This was accomplished by attaching a graduated aspirator to the Geissler potash bulbs containing the lia $(\mathrm{HO}))_{\mathrm{a}}$ solution.

The results obtained in these experiments are shown in Tible (;. Hammond claims that in his experiments a mouse invariably died within one hour. In our experiments all the animals lived over three hours, and some even longer than six honrs. The great difference in the duration of life for different animals may be accounted for in the varying susceptibility of different animals of the same species to the atmospheric conclitions in the jar, but the still greater difference in the duration of life in our experiments, as compared with Hammond's results, cannot be attributed to

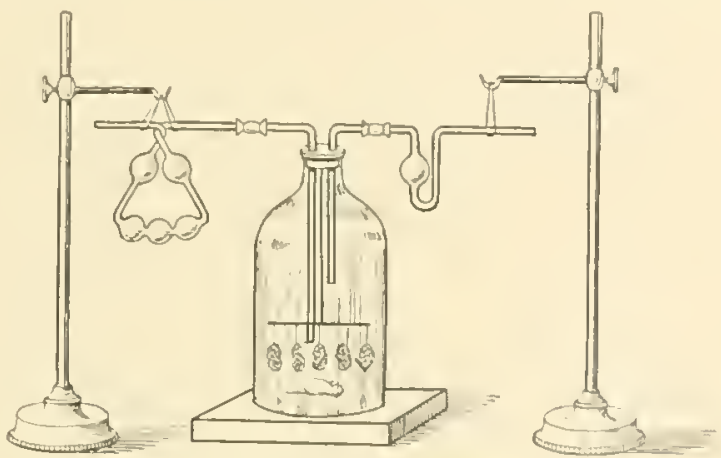

Fic. 5.-llammond's apparatus. the same cause, and, since it is not known positively what the capacity of the jars was which he used it would be useless to speculate on the point.

Fig. 5 shows Hammond's apparatus as given in his treatise (Fig. 10, 1) 170), and is an accurate representation of the apparatus uset ly us, except that it does not show the graduated aspirator connected with the free end of the Geissler potash bulbs, by means of which a known amount of fresh air was introduced at stated intervals during the experiment.

TABLE G.

THE " HAMMOND EXPERTIFNT."

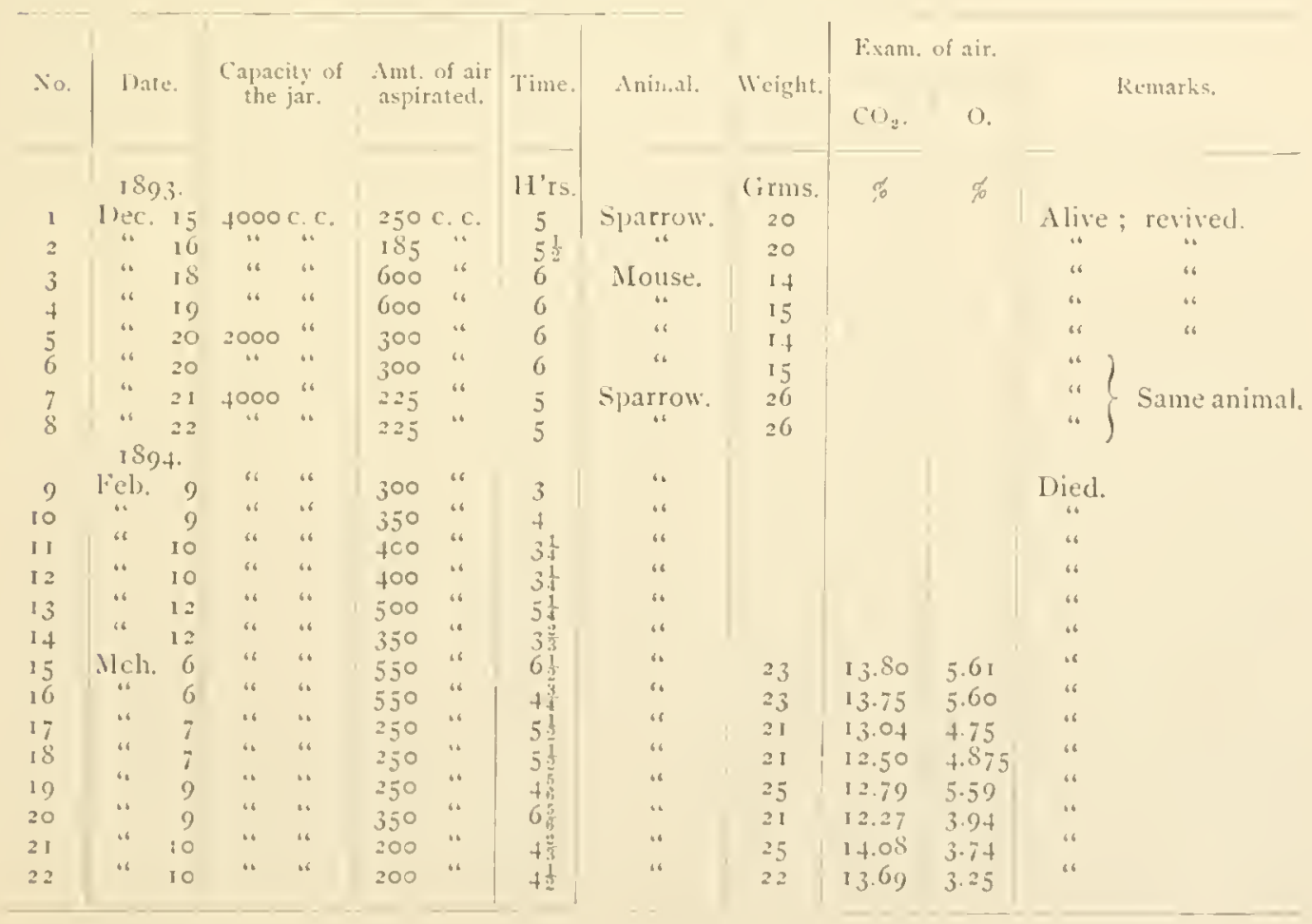


The determinations of the proportions of $\left({ }^{\prime}()_{2}\right.$ and of $O$ in the air of the jar at the end of the experiments were made with the bunte gas burette represented in lig. 6. For rapid determinations this apparatus gives quite sitisfactory results, and one soon learns to manage it easily and obtain results com ordant with those olnained hy other methods. It is not claimed that the results so obtained are absolutely accurate, lut any error resulting from the use of this burette is a constant one in all the air anilyses for the different experiments reported on, and is without influence on the results obtained.

a represents the burette proper; the upper portion is of larger size than the lower, which is marked with a scale extending from zero near the bottom to $100 \mathrm{c}$. c. just below the expanded por-

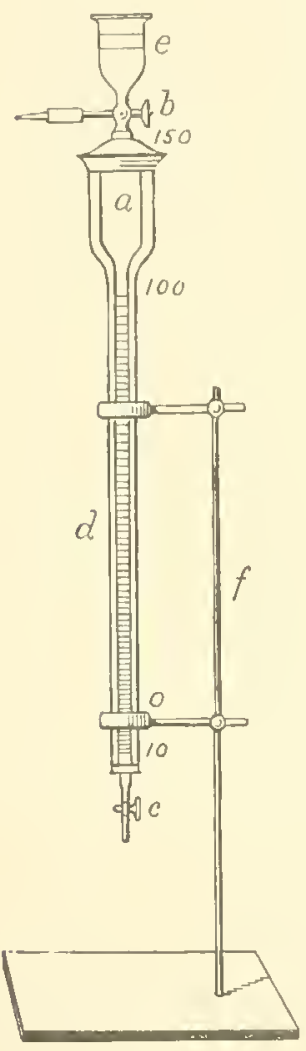

FIG. 6.-Bunte's Gas Burette $\left(X_{\frac{1}{10}}\right)$. tion above, and from the zero mark down to $10 \mathrm{c}$. c. near the lower cxtremity of the tube. 'l'he capacity from the Ioo c. c. mark to the threeway stop-cock, b, closing its upjuer end, is $50 \mathrm{c}$. c.-making the entire capacity of the tube $160 \mathrm{c}, \mathrm{c}$. The lower end is closed by means of a simple glass stopcock, $c$. $c$ represents a small cup at the top with marks at 20 and. 25 c. c. respectively, thus facilitating the measurement of the contained volume of gas at a constant pressure of known amount of water in the cup.

$f$ represents an iron stand to which the burette is firmly clamped.

a represents a glass tube of wider calibre surrounding the burette, flled with water and serving as a water-jacket to prevent rapid changes in temperature of the gases under examination.

METHOD OF USING BUNTE'S GAS BLRETTE.

The burette is filled with water and the three-way stopcock closing its upper end is so turned as to communicate through it with the external air, or with the vessel containing the air to be analyzed, by means of a short piece of rubber tubing connecting this stopcock with such ressel. By opening the stopcock, closing its lower end, some of the water, say 150 $c . c$, is allowed to flow out, and the air or gas to be analyzed flows in to take its place. When the desired amount of the sample of air has been taken, the lower stopcock is quickly closed and the three-wy stopeock is turned half-way round, thus bringing it in communication with the small cup at the top, which should also be filted with water to its 25 c. c. mark. The pressure of the contained air is now equalized and the communication with the cup is closed. A few drops of water always lodge just below the upper stopeock; these must be dislodged by gently tapping the iron stand o1) the floor. In a few minutes the volume of air may be read off. 'The burette is then connected at its lower end with a Chapman water pump and a portion of the water in it is drawn off. The water in the cup is then poured out aud about ro c. c. of a fo per cent. solution of sodium or potassium hydroxide poured into it, and in turning the stopcock, this flows in to take the place of the water just removed. The fluid and air in the burette are now gently agitated, at intervals, for five minutes, the cup is again filled with water to the $25 \mathrm{c} . \mathrm{c}_{\text {. }}$ mark, the stop-cock again opened, and the pressure of the gas equalized. If any of the water flows into the burette more must be poured into the cup to retain the gas under the original pressure of $25 \mathrm{c}$. $\mathrm{c}$. of water in the cup. This part of the operation requires some care and practice in order to prevent the escape of any of the contents of the burette or the entrance of external air. When the pressure is again equalized the rolume of gas is again read off, the reduction in volume representing the amount of $\mathrm{CO}_{2}$ absorbed, this is readily calculated to the per cent. of the original volume of gas.

The burette is now once more attached to the Chapman water pump to remore a portion of the fluid in the burette. About ro c. c. of a $\mathbf{I} 2$ per cent. solution of pyrogallic acid is poured into the cup and allowed to flow in. The fluid and gas are gently agitated, at intervals, during five minutes, the pressure equalized as before, the volume of gas read off, and the calculations for $O$. made as before. In most instances $N$. is the only gas remaining. 
From the deterninations of the proportions of ('( ) and of $\mathrm{O}$. in the air of the jar, after death of the animal, in the llammond exjeriments, it is evidemt that wo factors were operative in killing it. These were the low pereentage of (). present and the high jercentage of (C(), which the arrancements instituted for the absorption of this gats lad failed to remove. In a short time the exterior of the sponges became coated with bacO $\mathrm{C}_{3}$ wile the Ba(HO), in the interior becane inoperative. This sin be demonstrated by detemining the alkalinity of the thid expressed from the sponges, at the end of the experiment, with solution of oxalic acid. Another fact which substantiates such a conclusion is that of the clouding of the $\mathrm{Ba}(\mathrm{HO})_{2}$ in the Geissler potash bulbs guite early in the experiment from the ( $\mathrm{O}_{2}$ in the air aspirated from the jar in supply ing fresh air. While the solution of Ba(H() $)_{2}$ used in the sponges was twice the strength of that usually employed in COg, determinations in the Peltenkofer fask methoul, the amount of solution which can he taken up by the sponges of the siec used (about $10 \mathrm{r} . \mathrm{c}$. each) is entirely too small to alsorb more than a fractional part of the $\mathrm{C}^{(} \mathrm{O}_{2}$ generated by an animal during the time of an experiment.

The morle of death in these experiments presented such a close similarity to that noted in cases of $\mathrm{CO}$, poisoning. uncler other circumstances, that it was impossible to distinguish it from death produced ly that gas. Judging from the air analyses at death of the animals, from the constancy of the symptoms and the close similarity of the gaseous contents of the jars at death of the animals, and, besides these, the alsence of any positive indications of the presence and action of other poisonous expiratory products as manifested either ly the action of the animals or the mode in which death took place, it is safe to conclude that the low percentage of (), logether with the high pereentage of $\mathrm{CO}_{2}$, in the amosphere of the jars, were the principal causes of death. The mokle of death differed in no particular from that noted in the case of animals dying in the closed vessels, in the "lirown-seyuard" experiments, or in those male with artificial gaseous mixtures where sufficient oxygen was present to support life for several hours. Another fact, observecl likewise in all the other forms of experiment reported on, was the prompt reviral of the animals when removed from the jars and supplied with fresh air. In exceptional cases, where the animal was not removed until death was certain to take place in a very short time, the revival of the animal clicl not follow on remoral from the jar, lut death supervened at a shorter or longer period after removal. The failure of these animals to revive might be attributed to the presence of anti-mortcm clots within the heart avities produced by the long-continued respiration of sucl bigh percentages of Co. as existed in the atmosphere of the jars in this and the other experiments. The prompt revival of the animals removed from the jars a little earlier appeass to be an additional indication that the symptoms produced in these experiments had been due to the relatic proportions of $O$ and $\mathrm{CO}_{2}$ present in the atmosphere which the animals breathed. The effects of an organic volatile poison would not allow such rapid recovery, and woukd most probably wanifest itself by continued ill-health on the part of the animals suljected to it.

Some animals viciated the contained air more rapidly than others, so that, while there is a close relation between the composition of the atmosphere at the end of the experinents, it is evident that the degree of respiratory interchange determined the duration of life for each individual. The room temperature for these experinents was very nearly constant-1 $8^{\circ}$ to $25^{\circ} \mathrm{C}$.

A further attempt was made by modifying the :pparatus. This modification is shown in lig. 7. Here the (O) is absorbed by passing the air, issuing from the bell-jar containing the animal, through five leettenkofer alsurption tubes, each comaining $100 \mathrm{c}$. C. of a strong solution of Ba( $(1)_{(1)}$

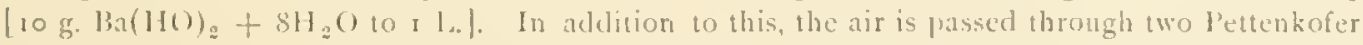
tubes, each containing $100 \mathrm{c}$. c. of Jiuchuer's alkaline pyrogallate solution, to remose some of the 1) from the air. The moisture is alsorbed by $\mathrm{CaCl}_{2}$ placed in a shallow vesscl, covered with a perforated porcelain plate, in the bottom of the leell-jar.

IESCRIPTION UF THE APPARITLS ISED IN THE MOLIFIEI "HAMMOND" EXPFIRIEXT, FIG, 7.

a represents a one-litre bell-jar resting on a gromul-glass plate, and contains a shallow vessel with $\mathrm{CaCl}_{2}$. The vessel containing the CaC $\mathrm{I}_{2}$ is covered with a perforated porcelain plate on which the mouse under experiment is placed. 
$b b$ are the two asprirating flasks, of four litres" "apacity, partially filled with saturated salt solution. liy reversing their positions these aspirators give a continuous current of air. 'lhe rubber cork closing the top of these Hasks carries two glass tulues with glass stofjecks, and the apparatus is so constructed as to maintain the air current in the same direction by closing one, and opening the other, of these glass stupcoks when the tasks are reversed in their positions.

The Pettenkofer tules rontaining the $\mathrm{Ba}(\mathrm{H}())_{2}$ are ataclicel to the stative $c$, and those containing the pyrogallate solution to the stative $d$.

$c$ represents a stopcork in the tubing connecting the aspirators. This serves to control or arrest the aspiration.

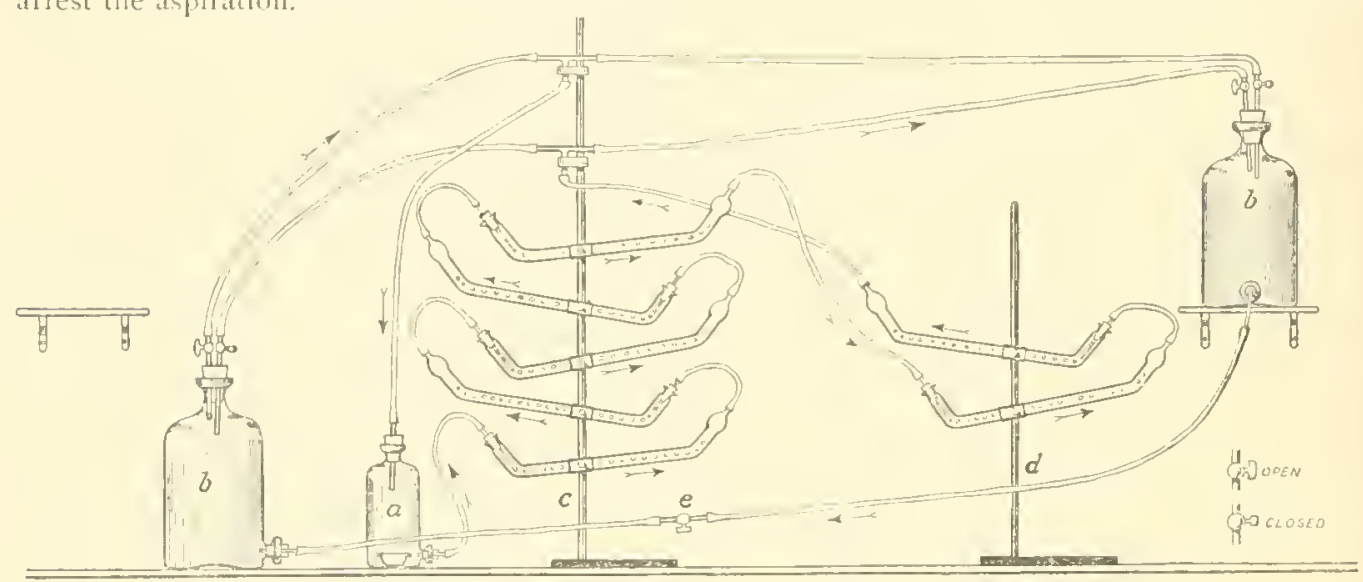

FiG. 7.- Modified Ifanmond Apparatus (devined by Abhott).

The results obtained with this modification of the apparatus are shown in 'Table $H$. The same animal was used in each of the six different experiments performed, and it failed to succumb to the conditions present in any of them. In the later exferiments, in which the animal was placed in a one-litre bell-jar, it failed to reduce the proportion of $O$ in the volume of air within the apparatus (about six litres) to such an extent as to endanger its life, even with the additional rechetion of $\mathrm{O}$ taking place in the two Pettenkofer tubes containing Buchner's solution of alkaline pyrogallate. The percentage of $\mathrm{CO}$, remained quite low through the absorption by the $\mathrm{Ba}(\mathrm{HO})_{2}$ in the five Pettenkofer tubes. The construction of the apparatus permitted the continuous circulation of the air within the apparatus so that the animal was constantly breathing air that had been breathed and

TABLE H.

MODIFIED "HAMMOND" EXPFRIMENT.

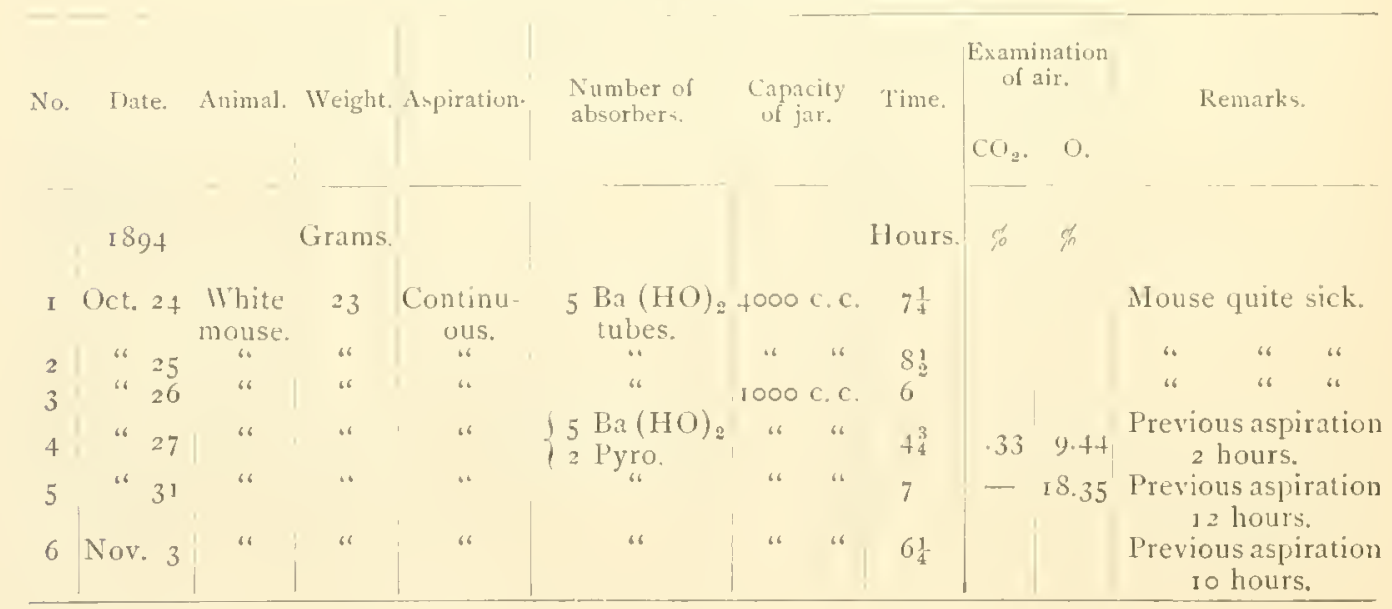


rebreathed before. The direction of the air current through the apparatus is show $n$ by the pontion of the arrows in the figure. Hy changing the position of the aspirating flasks, and turning the stopcocks in the glass tubing inserted through the stoppers closing the upper copenings of the aspirattors, the current was maintained in the same direction as before, and the entrance of external air was thereby prevented.

The results oltained show that, with the alsorption of the $\mathrm{CO}_{2}$ as gencrated, the motse remained relatively comfurtahle in the atmosphere present and that no deleterious effects developed from the continued rebreathing of the air confined within the apparatus. The animal seemed to be somewhat oppressed toward the close of each experiment, but revived quickly after remoral from the appraratus.

The air contained in the two aspirating flasks was retaincl each time in the later experiments. Consecpuently in these experiments the fresh air-supply comprised only that which was enclosecl in the Pettenkofer tubes, the rubber connecting tubes, and in the bell-jar containing the animal. In several of the later experiments the volume of air within the apparatus was aspirated continuously through all its parts for some hours hefore beginning the experiment. In this manter the pure air-supply was reduced to one litre, the amount of air in the bett-jar containing the animal.

V.- Experiments to determine the proportions of $\mathrm{CO}$ and of 0 in the air of a glass vessel in which small animals (mice and birts) had remained until death was produced, and the effects of different temperatures upon the cluration of life and on the composition of the residual atmosphere after cleath in such cases.

The results obtained in these experiments are shown in Table 1. At the room temperature death did not take place until the amount of oxygen present was too low to support life. At a higher or lower temperature there was a slightly shorter duration of life, varying with the amount of increase or reduction of the temperature.

TABLE 1 .

EXPERIMEXTS WITI AXIMAIS IX゙ CIUSED VESSELS-ATMOSPHERIC AIR.

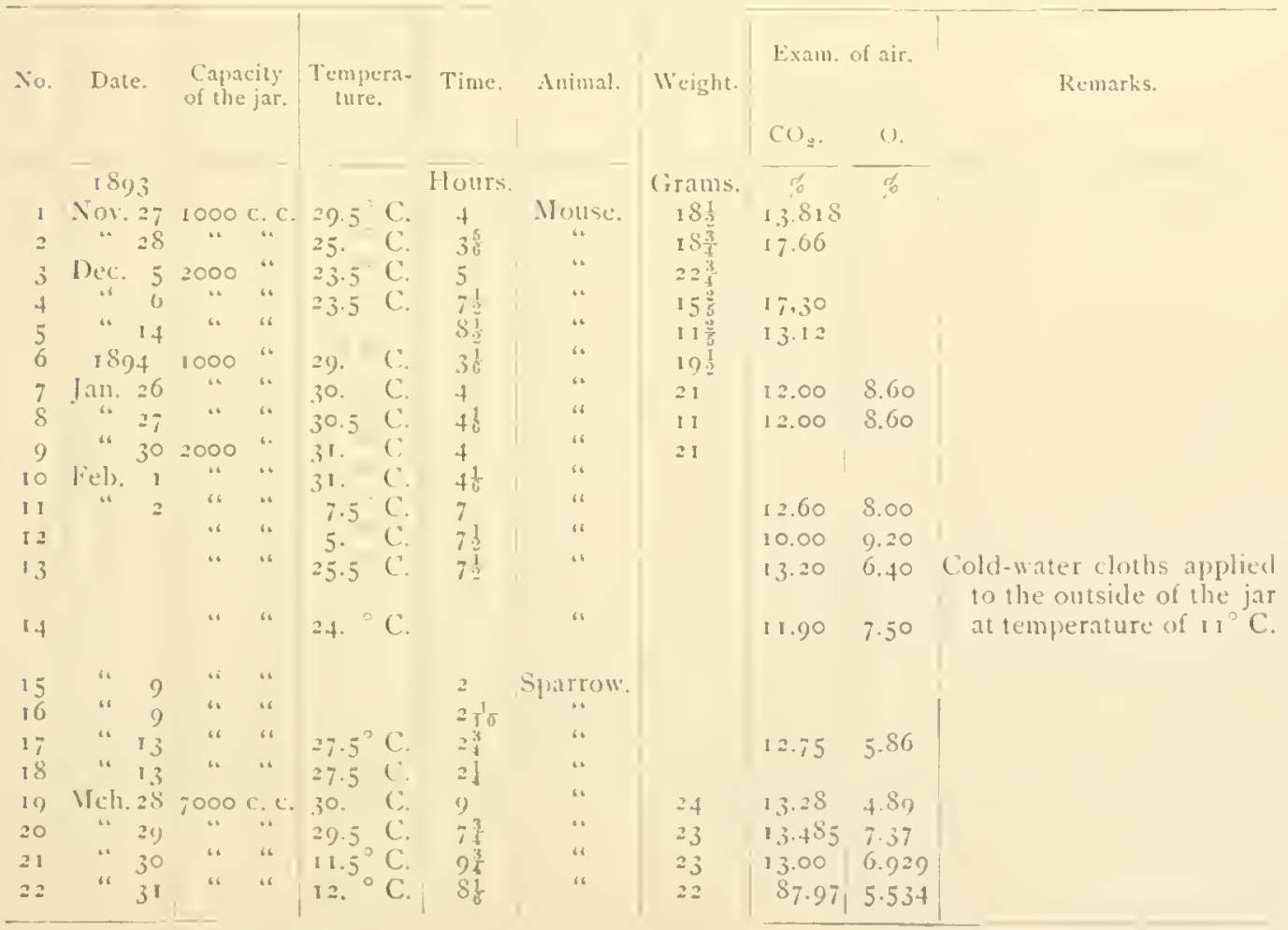


The efferts of temperature upon the duration of life in a confined spare (and even in the open air) are hetter shown in the repetition of Richardson's experiments (8), as presented in 'Table J. The results olutained in these experiments show that the duration of life is very perceptihly shortened through the influenec of a bigher as well as of a Jower temperature than $181020^{\circ} \mathrm{C}$.

\section{TAнI: J.}

"RICHARIMOX'S" FXPERIMFNT.

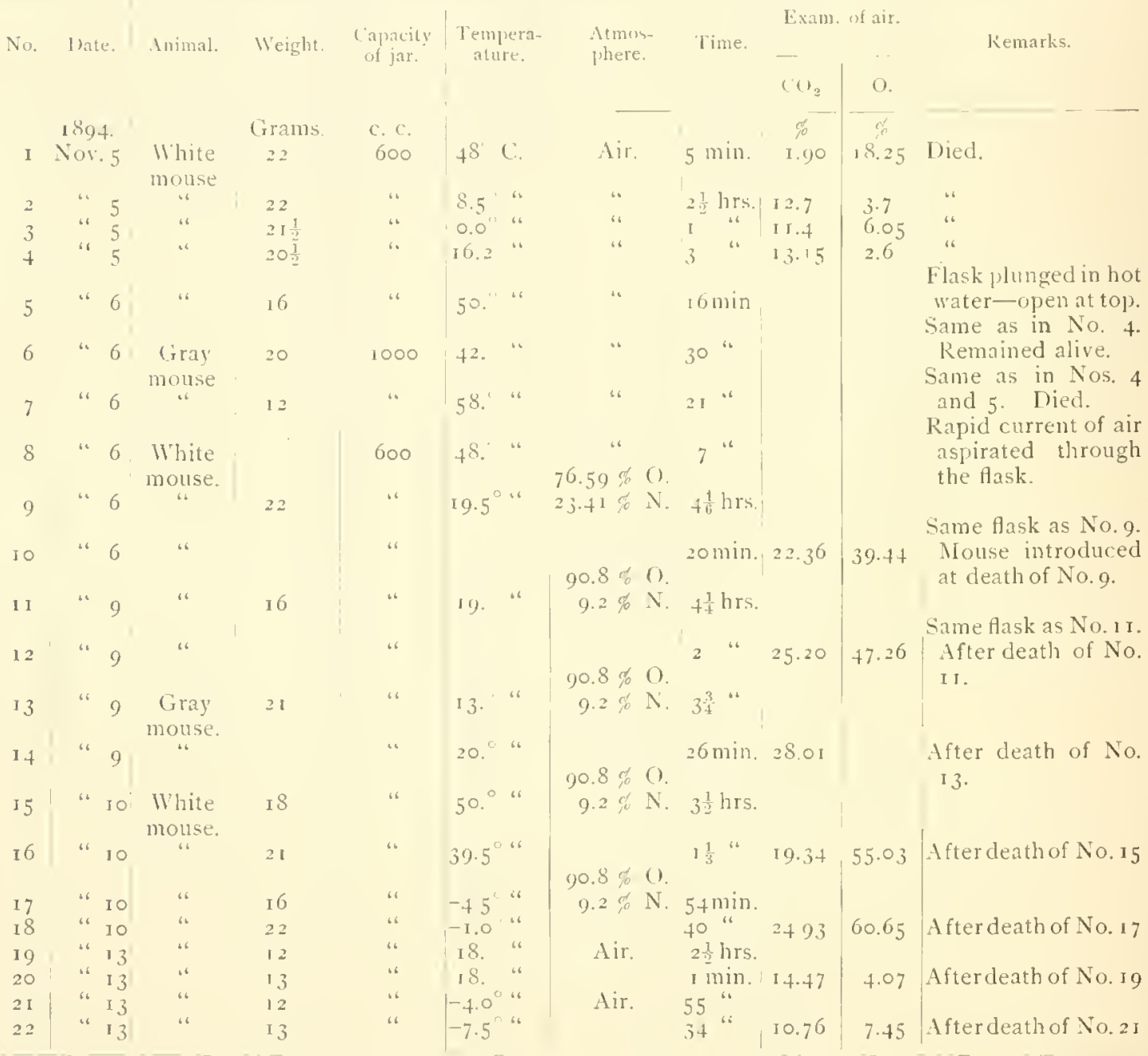

An interesting condition noted in autopsies upon a number of the animals that succumbed to the conditions in the "Richardson" experiment was that of the blood in the heart of the animal. In the cases where death supervened in a short time, the heart blood was fluid and seemed to lack the power of coagulation, while in those cases in which death resulted after several hours' confinement in the flask, the cavities of the heart contained firm, dark clots of blood. This condition of the blood was, no doubt, due to the influence of the $\mathrm{CO}_{2}$ generated by the animal during the experiment. 


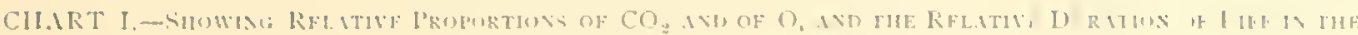

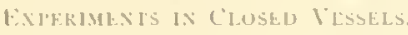

\begin{tabular}{|c|c|c|c|c|c|c|c|c|c|c|c|c|c|c|c|c|c|c|c|c|c|c|c|c|c|c|}
\hline & & & Ki & & & & $2-$ & & "4p? & & $\Leftrightarrow \mathrm{re}$ & $\begin{array}{l}\text { lati } \\
\text {.. } \\
\text {.. } \\
\text {. }\end{array}$ & & $\begin{array}{l}\text { per c } \\
\text { dura } \\
\text { roon }\end{array}$ & $\begin{array}{l}\text { cint. } \\
\text { tion } \\
\text { tem }\end{array}$ & $\begin{array}{l}\text { of } \\
\text { of tif } \\
\text { apera }\end{array}$ & $\begin{array}{l}\mathrm{O}_{2} \text { at } \\
\mathrm{O} \\
\text { fe. } \\
\text { aure. }\end{array}$ & I & se of & exp. & & & & & & \\
\hline & & 1 & 2 & 3 & 4 & 5 & & 6 & 7 & 8 & 9 & & 10 & 11 & 12 & 13 & 14 & 15 & 16 & 17 & 18 & 19 & 20 & 21 & 22 & \\
\hline 90 & -5 & & & & & & & & & & & & & & & & & & & & & & & & & 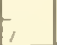 \\
\hline 808 & +0 & & & & & & & & & & & & & & & & & & & & & & & & & 2 \\
\hline 08 & {$\left[\begin{array}{r}0 \\
35 \\
\end{array}\right]$} & & & & & & & & & & & & & & & & & & & 1 & ] & & & & & 3 \\
\hline $80^{4}$ & $-\frac{\pi}{30}$ & & & & & & & & & & & & & & & & & & & & & & & & & 4 \\
\hline $\begin{array}{r}5 \\
50 \div \\
\end{array}$ & $\begin{array}{r}-8 \\
25\end{array}$ & & & & & & & $\rightarrow$ & & & & & & & & & & & & $\infty$ & -0 & & & & & 5 \\
\hline$-\begin{array}{l}-0 \\
+0\end{array}$ & $\begin{array}{r}-4 \\
20 \\
\end{array}$ & & & 0 & & & & & & & & & & & & & $\sigma$ & & & & & & & & & to \\
\hline \begin{tabular}{r|r|}
3 & 5 \\
30 & 0 \\
\end{tabular} & \begin{tabular}{|r|}
8 \\
5 \\
5 \\
\end{tabular} & & & & & & & & & & & & & & & & & & & & & & & & & 73 \\
\hline $20^{\circ}$ & $10^{2}$ & & & & 1 & & & & & & & & & & & 1 & & & & & & & & & & s \\
\hline 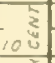 & $\begin{array}{r}5 \\
5 \\
\end{array}$ & & & & & I & & & & & & & & & do & &. & & & & & & & & $\begin{array}{l}1 \\
-3\end{array}$ & 10 \\
\hline 8 & & & & & & & & & 4 & & & & & & & & & & & & & & & $:$ & & \\
\hline
\end{tabular}

Chart 1. shows the relative duration of life, the relative proportions of ${ }^{\prime} \cap_{z}$ and of $O$ at death of the animal, in the experiments with animals in closed vessels containing atmospheric air.

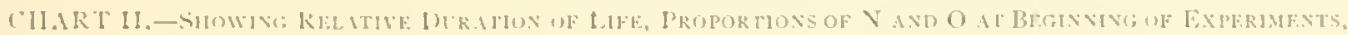

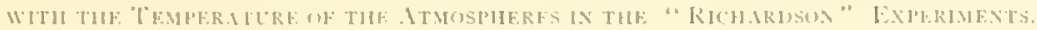

$$
\text { Key }\left\{\begin{array}{cccc}
- \text { kepresents relative per cent of } x . \\
-x-x-x & . & . & \text { " } \\
& . & . & \text { duration of life. } \\
-0-0-0 & \text { " } & \text { ". } & \text { temperature in the flask. }
\end{array}\right.
$$

\begin{tabular}{|c|c|c|c|c|c|c|c|c|c|c|c|c|c|c|c|c|c|c|c|c|c|c|c|c|}
\hline & & 1 & 2 & 3 & 4 & 5 & 6 & 7 & 8 & 9 & 10 & 11 & 12 & 13 & 14 & 15 & 16 & 17 & 18 & 19 & 20 & 21 & 22 & \\
\hline 92 & 50 & & & & & $T$ & 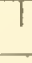 & $T$ & 1 & & 7 & & & & 1 & & & & 1 & & & 1 & 1 & \\
\hline & {$\left[\begin{array}{ll}6 & 6 \\
0 & 0\end{array}\right.$} & & & & & & & & & & & & & $\frac{1}{3}$ & & $\mid \begin{array}{l}1 \\
x \\
y \\
y\end{array}$ & 1 & $y$ & & & & & & $t$ \\
\hline & so & & & & & & & a & & & & 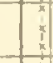 & & $\begin{array}{l}\hat{1} \\
\vdots \\
\vdots \\
x\end{array}$ & & $\mid \begin{array}{l}1 \\
1 \\
1 \\
x\end{array}$ & & $\begin{array}{r}4 \\
4 \\
4\end{array}$ & & 1 & & & & 5 \\
\hline $50^{\circ}$ & $20^{\circ}$ & 9 & & & & & 6 & & 19 & & & & & & & & & 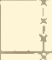 & & & & & & $-\therefore$ \\
\hline 5 & -30 & & & & & & & & & & & & & & & & 9 & & & & & & & -5 \\
\hline$=0$ & & & & & & & & & & , & & i. & & & & $\begin{array}{l}4 \\
y \\
x\end{array}$ & & 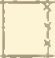 & & & & ! & & 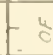 \\
\hline & 50 & & & & & & & & & 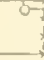 & & & & $\sigma_{1}^{3}$ & & $\begin{array}{l}1 \\
x \\
x\end{array}$ & & & & 9 & 9 & 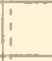 & & -3 \\
\hline$=00^{\circ}$ & 5 & & & & & & & & & 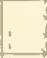 & & र्र & & : & & 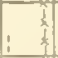 & & & 1 & 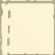 & & $i$ & & 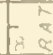 \\
\hline 5 & 5 & & & & & & & & & 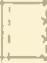 & & 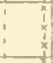 & & & & $\begin{array}{r}\hat{1} \\
\vdots \\
\end{array}$ & & $b \frac{x}{x}$ & 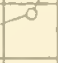 & 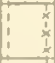 & & $\therefore a_{1}$ & or & 9 \\
\hline$F$ & $E$ & & & & & & & & & 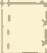 & & & & & & & & & & & & & & 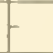 \\
\hline
\end{tabular}

(Hart 11. shows the relative duration of life, the relative proportions of $\mathrm{N}$ and of $\mathrm{O}$ at the beginning of each of the "Riciardson" experiments, also the temperature curse for the entire series. 
TABLE K.

EXPIRIMENTS WITH ARTHICIAI, ATMOSPHERES,

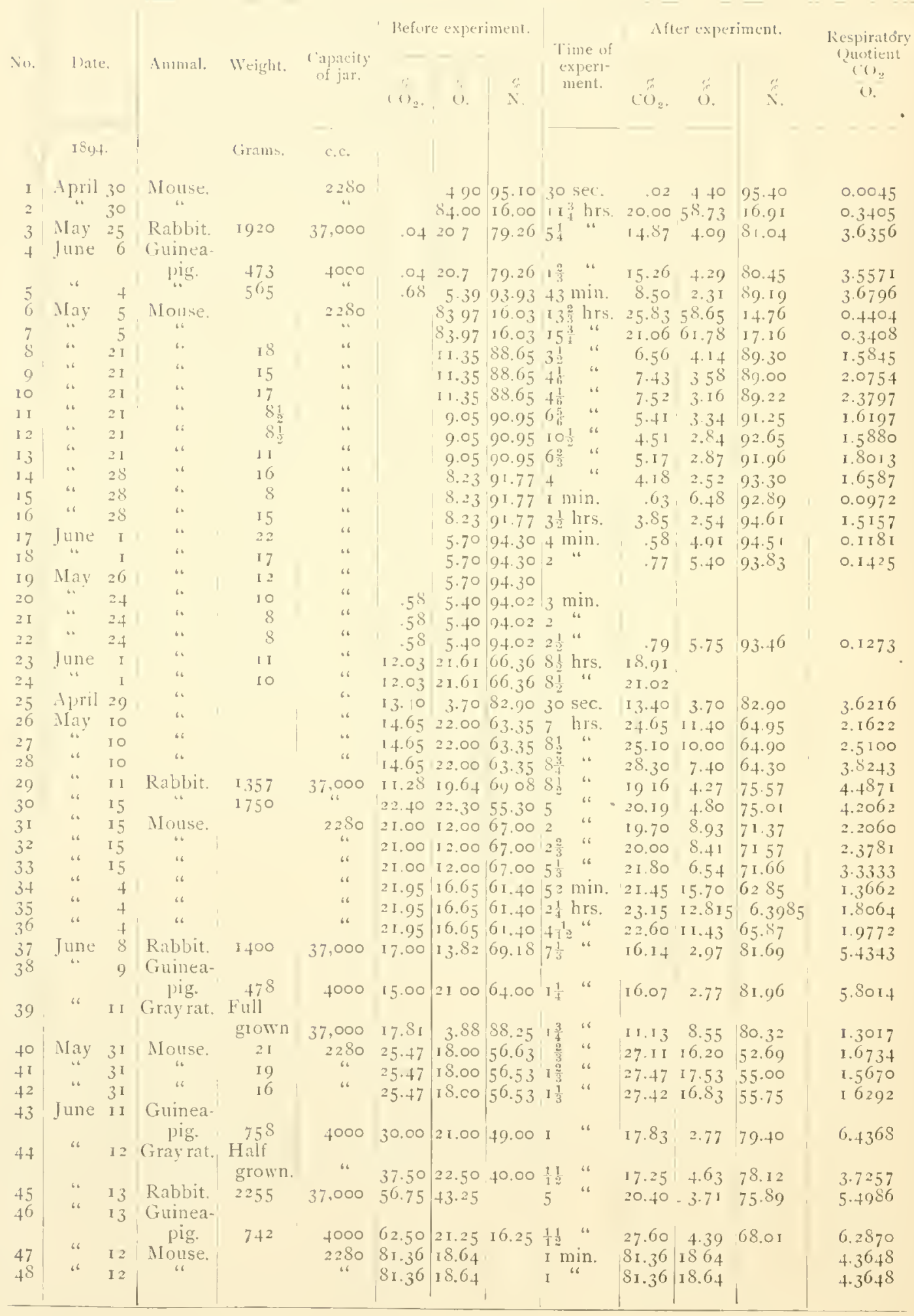


In order to ascertain whether an atmospluere which had served for respuratiun, once or oftener, affected an animal difierently from an atmosphere made up artuficially from pure gases to the sume proportions as found in the analysis of the atmospheres in the different experiments repurted un, a series of experiments was undertiken to determine the effects of gaseous mixtures made up w varying proportions of ( $(1,2,()$, and of $X$. The results obtained in this series of experiments are show $n$ in lable $K$. giving the capacity of the jar, the weight of the animal. the comprosition of the atmosphere lefore and after the experiment, and the duration of lite in such an amospluere. The construction of artificial atmospheres, and the introduction of an animal into sue h an atmosphere without considerable alteration of the proportions of the different gases, through the aceadental introkluction of atmospheric air, was not always found an easy matter. "The chef difficulty was unfortunately a fundamental one. in that the $\mathrm{C}_{2}$ was not entirely free from atmospherir air ; the oxygen contained more than to per cent. of $X$; while the attempt to olntain pure $X$ from atmospheric air ly means usually employed for this purpose-burning out the $O$ with phosphorus-gave variahle results with each attempt, the proportion of o remaining after the absorption of the $P_{2}()_{5}$ usually ranged from 2 to 5 per cent. Cnder these circumstances it will be seen that there was an almost insurmountable difficulty to the construction of an atmosplyere having the exact proportions of the different gases predetermined for $i t$, and alundant evidence of this difficulty was obtained from analyses of the mixtures after sufficient time had leen allowed, as was sipposed, for the diffusion of the gases.

The thorough diffusion of the components of gaseous mixtures appears to be a slow process. rwenty four hours, or longer, was usually allowed for this to take place, yet from the variable lengths of time during which animals of the same size and apparently possessing the same amount of vitalieg could survive in atmospheres of equal volume made up from the same mixture, and the variable proportions of the different gases found on analysis after death of the animals expessed to these atmospheres, show that perfect diffusion had not always taken place. 'Jhese diserepancies in the construction of the gascous mixtures are to be regretted, though they are not great enough to vitiate the value of the experiments taken as a whole. The positive character of the results is ton evident to allow these difficulties to have much weight.

There is an uncertain feature in the eleterminations of the proportions of ( 1$)_{2}$ in the gaseous mixtures, after leath of the animal, in those instances where this gas was orininally present in high percentages. On this account it would les well to bear in mind that the bird column representing the proporions of the different gases present at death, marked $\mathbf{N}$, represents, in fact, the gises which failed to be absorbed in the gas-burette by the solutions of caustic suda and of pyrogillic acid used to absorls the ( $\left(\mathrm{O}_{2}\right.$ and 0 present. There is no doubt as to the presence of the proportions of $\mathrm{C}_{2}$, as stated in the different experiments, before placing the animal in the mixture. Whether a large proportion of the ('O, was likewise absorbed by the animal, it is impossible to saly. There is no probability that such was the case. I part of the loss of $\mathrm{CO}$, may also be accounted for in the method employed in making the gaseous mixiures. Thene mixtures were made lyy displacing water from the jars which were to contain them. The water may have taken up the (1): more readily than the other gases, especially where this was the first gas introduced incer the jar, and may, therefore, have been a slight source of variation in the composition of the mixture: yet, it seems, from analysis made just before placing the animal in the mivture, that the loss in this manner was very small. "The desired proportion of CO. was usually present, even afier twenty-four hours had been allowed for diffusion to take place.

(hart 1Il. shows the results oltained in these experiments as to the relative duration of life and the relative proportions of (C). and of () at the beginning of the experiment, as well as att death of the animal. In comparing this chart with Chart l., it must be remembereel that in this series of experiments the compostion of the atmosphere was a different and sariable one, while in the series of experiments shoun in (hart 1 , the composicion of the atmosphere at the beginning of the experiment was invariably the same-ie, atmospheric air. 'l'his fact, alont with the varlations in size of jar for different animals, explains the longer or shorter duration of life in this serie's of experiments as compared with that presented in Chart I. The very important influences of these 
variations must be kept in mind constantly in comparing these two charts, as well as in comparing the results obtained in any of the other forms of experiment.

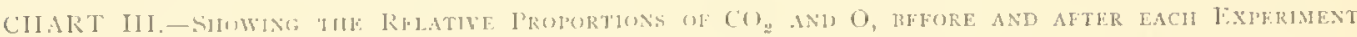

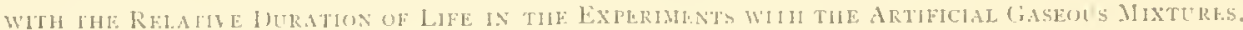

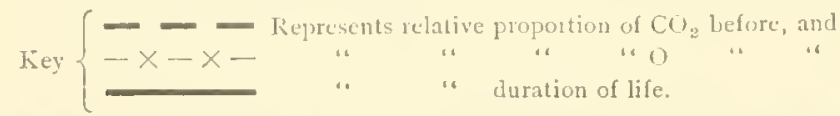

\begin{tabular}{|c|c|c|c|c|c|c|c|c|c|c|c|c|c|c|c|c|c|c|c|c|c|c|c|}
\hline & & 1 & 2 & 3 & 4 & 5 & 6 & 7 & 8 & & e & 10 & II & 12 & 13 & 14 & 15 & 16 & 17 & 18 & 10 & 20 & \\
\hline & & & & & 1 & 1 & & & & & & & & & & & & & & & & & \\
\hline & & & & & & & & & 1 & & & & & & & & & 1 & & & & & $4 \quad 5$ \\
\hline & & & & & & & & & & & & 1 & & & & & & & & & & & 6 \\
\hline & & & & & & & & & & & & & T & & 1 & & & & & & & & 83 \\
\hline & & & & & & & & & & & & & & & & & & & & & & & 100 \\
\hline & & & & & & & & & & & & & & 7 & & & & & & & & & $1 / 2$ \\
\hline & & & 1 & & & & 11 & & & & & & & & & & & & & & & & $14 z$ \\
\hline & & & & & & &,$\therefore$ & & & & & & & & & & & & & & & & $16 \approx$ \\
\hline & 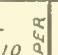 & & & & $\cdots$ & $y$ & i & & & & & & & & & & & & & & & & 8 \\
\hline & & $x_{1}$ & & 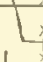 & - & & & & & & -7 & $\cdots$ & $=-\frac{1}{y}$ & $-\frac{1}{1}$ & $=-\frac{1}{1}$ & $t=1$ & & 辛 & & $\tau_{1}$ & 1 & & \\
\hline
\end{tabular}

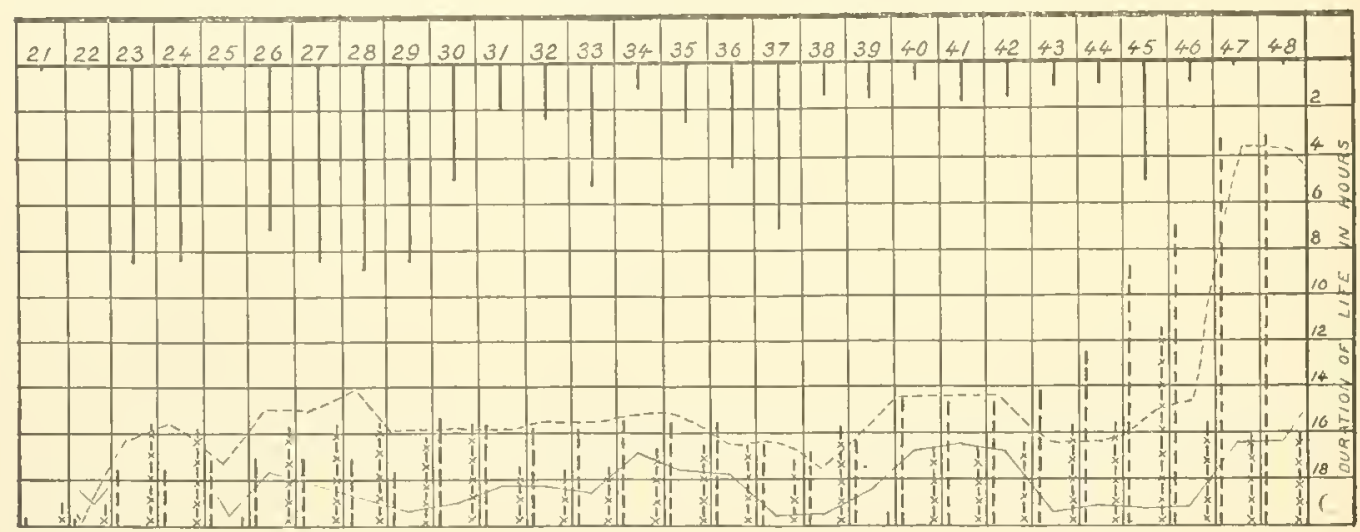

The mode of death in these experiments, when sufficient $O$ was present to support life for several hours, was similar to that noted in the "Hammond" experiments, in the experiments with atmospheric air in closed vessels, and in the "Brown-Séquard "experiments, and could not be distinguished from death in $\mathrm{CO}_{2}$ poisoning. When such an amount of $\mathrm{O}$ was not present, death was often almost instantaneous, following, at the longest, within frc minutes after the animal was placed in the jar. After a few gasps and several violent struggles, life became extinct.

A number of the animals used in this series of experiments were examined post mortem. The gross appearances presented in these animals were of the character of those found ordinarily in cases of $\mathrm{CO}_{2}$ poisoning. Intense venous engorgement was noted in all the organs and tissues. 
The heart invarialbly contained large, firm blood-clots, dark in color, cxteneling from the aurieles into the ventricles. This was usually most markert on the right side.

Microseopic examination of the organs hardened in alcohol and mounted m celloidin, presented no other comstant conditions than those brought about by the mode of death-the cxtensive venous engorgement. The very slight pathological changes noted in isolated cases, frum the rapidity with which death ensued on exposure to the atmospherie conelitions presemo, must be attributed to causes antedating the time of the experiment by a considerable period. The changes here referred to were mostly of the nature of interstitial changes present in the liver and kielncys. No trace of the poisonous effects of any other respiratory products was noted in any of the animals examined.

The results obtained strengthened to a satisfactory degree the conclusions clrawn from the results obtained in the other experiments reported on. It was shown that in the alsence of a sufficient proportion of $(1$ in the artificial gascous mixture to support life-at least 5 per cent. - the animal spectily succumbed. On the other hand, $\mathrm{CO}_{2}$ could be present in quite large proportions, as long as sutficient $O$ was also present to support life for some time, and no untowarel efferts were manifested. 'The different animats used in these experiments-sparrows, rats, mice, gumea-pigs, and rabbits-manifested no distinct differences in susceptibility to the conditions present.

VI.-Experiments in the inoculation of animals with the moisture condensed from the exhaled breath, as conducted by Brown-Séquard and d'Arsonval, by Hofmann-Wellenholf, and others. Four series of animals were inoculated with the fluid as shown in Table $\mathrm{L}$.

SERIts 1,-The fluicl, clear, limpid in character and without odor, of which 2 r c. c. had been collected from the breath of a healthy person on December 5, 1893, was warmed by holding the receptacle containing it in a vesnel of wam water, about $35 \mathrm{C}$. 1 rabbit, weighing $1870 \mathrm{~g}$. received $x_{4}^{3} \mathrm{c} . \mathrm{c}$. into the large vein at the margin of the ear. Another rabbit, weighing $1820 \mathrm{~g}$. also received $\mathrm{r}_{4}^{3} \mathrm{c} \mathrm{c}$. in the same manner. I guinea-pig. weighing $220 \mathrm{~g}$., reccived $+\frac{1}{\mathrm{c}}$, c. into the peritoneal cavity. A second guinea-pig. weighing $280 \mathrm{~g}$, also received $+\frac{1}{\mathrm{c}} \mathrm{c}$. into the peritoneal cavity. A third guinea-pig, weighing $220 \mathrm{~g}$., received $4.1 \mathrm{c}$. c. of sterilized distlleel water into the peritoncal cavity as a control.

'l'hese animals were kejt unter careful observation for more than a month, and as mothing unusual in their condition presented itself, they were released.

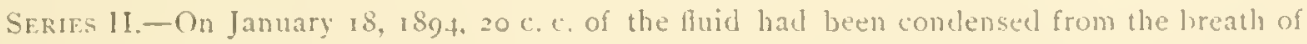
the man hasing the tracheal fistula. The flud was warmed by holding the receptacle containing it in a vessel of warm water, ahout $3^{6} \mathrm{C}$.

(If this fluid 5 c. c. were injected into the peritoneal cavity of each of three white rats : a fourth rat receiving $5 \mathrm{c}$. c. of sterilized clistilled water into the peritoneal cavity as a control experiment.

INOCULATIONS WITH CONDFNSTI FLUID OF EXPIRED RREATII.

TABLE: L.

SERIES I.

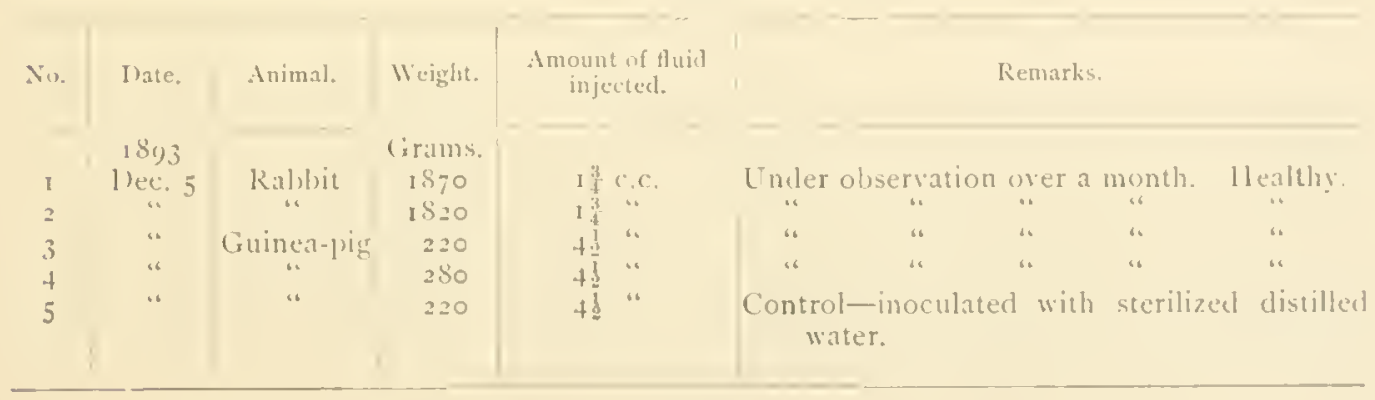


SERIES II.

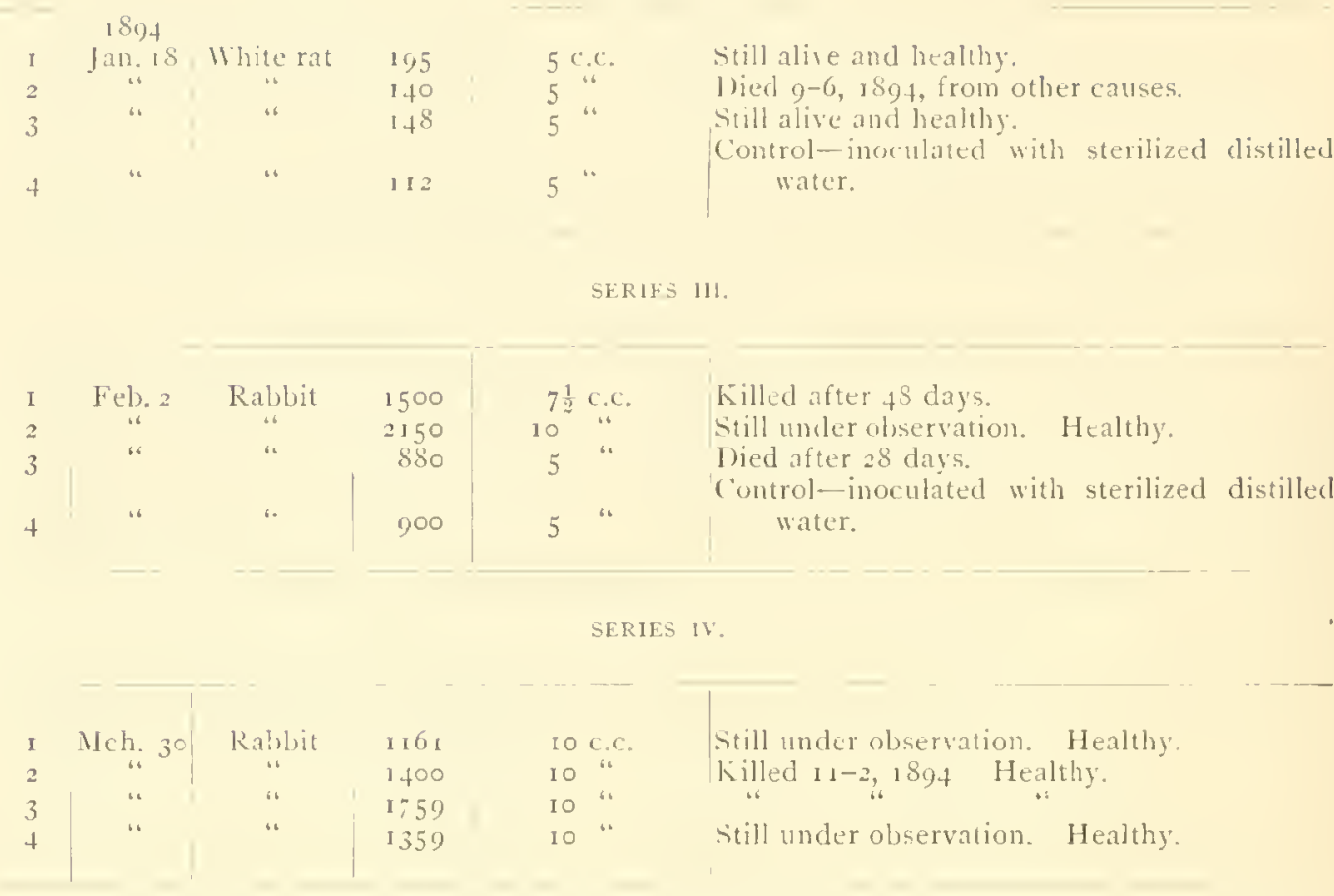

These animals were under close observation for several months without noting any alteration in their condition. One of them has since died (Sepr. 6,1804 ) from other causes. The others continue well.

SERIEs 1]I.-On February I, 1894,44 c.c. of the fluid had been collected from the exhalations of the man having the tracheal fistula. This fuid was again warmed, as before, to about $35^{\circ} \mathrm{C}$., and injected into the jeritoneal cavity of rabbits as follows:

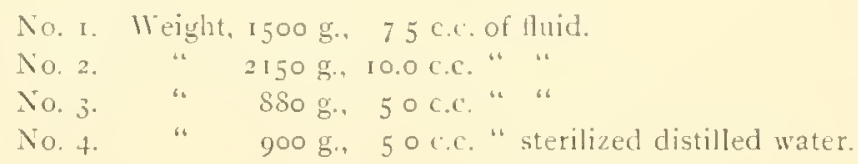

Rabbit No. 3 of this series died during the night of March 4,1894 , and an antopsy held the next morning showed the following conditions *

Young female rabbit. Extemally: Not very thin, adipose not quite used up. Internally: On opening the abdominal cavity the organs were found in normal position. Stomach and large intestines well filled. Liver slightly enlarged, no spots: shows lobular appearance well marked; rather pale in color, as are all the organs and tissues (albino). Call bladder well filled with pale bile. Small intestines molerately filled; no change in their appearance: Peyer's patches not enlarged. Apjendix not inflamed. Spleen not enlarged. Kidneys normat in size. Adrenals small. Lungs normal, rather pale. Heart rather pale, contracted on left side, right side filled with blood.

Cultures were taken from the liver, spleen, blood, and abdominal fluid and all proved negative

Microscopic examination of the organs: Kidney: Presents some blood-ressels which contain an increased amount of white blood corpuscles. Cilomeruli are slightly swollen, showing a small

\footnotetext{
* Autopsy made by Dr. Ulmsted.
} 
amount of infiltration. Slight increase of connective tissue between the tulules. l.arge hlookvessels are very much dilated. Areas of slighe extravasation. I certain amount of , loudy swelling. I.iver-show large number of small areas of cell-death-necrotic areas. lireaking up of cells and iragmentation of the nuclei, which is almost identical with the conclitions tomme in

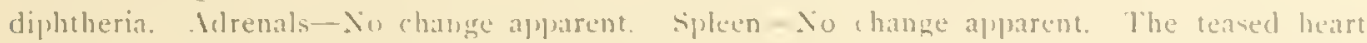
musele, treated with acetu acid, shows possibly a trace of fatty degencration. Xo " njilespread echymoses and hemorrhages in the lungs and intestines " werefound, as reported by brown-Seipuarl and (l'irsonial.

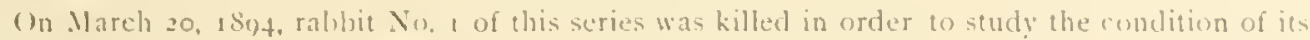
organs and compare the results with the conditions found in rabbit dio. 3. Weight lefore deatls, I $S_{30} \mathrm{gr}$. gain $3,30 \mathrm{~g}$. It seemeel to be in perferet bealth.

(3) opening the abdominal casity the organs were found in mormal position. No increase of peritoneal fluid. (on the liver a number of points (psorosperms?), one a depression $\frac{1}{2}$ mum, in depth, graysh-white in appearance, were noted; mosty on the left lobe. Several other small areaswhitish in appearance, sharply limited in their outline, smaller than the last, not distinctly depressecl. ustlally two, three, or more together-- were found scattered over the upper and lower surfaces of the liver. The liver is clark in color, lobules well narked out; of about normal swe and consisteney. cutring into the liver there is the usual amount of hemorhage. Spleen-small, if anything. it is contracted, otherwise of normal appearance. Adremals appear normal. Kinlneys-limbedded in usual amount of fat Normal in size, color, and consistency. Small echinococcus cyst in the great onentum, and another in the liver. Jutestines nomal in apjearance. Heart normal in appearance. P'ortion of muscle teascel with salt solution and treated with acetic acid show's no fatty change. l,ungs normal in appearance.

Cultures were taken from the peritoneal Iuid, liver, spleen, kidneys, and blood. All proved negative.

Microscopic examination of the organs: l,iver-Cuntains a small hemorrhage at the depressed part noterl at autopsy. The other spots noted are found to be entirely superficial. Sight inerease of connectibe-tissue elements. lingorgement of a capillary noted. Ridney-Nephritis manifested ly some congestion of vessets, proliferation of the connective-tisstle cells between the tubules and around the glomeruli ; an occasional glomerulus being quite contracted. spleen shows an increased anount of pignemt.

'The remaining rabbits of this series have continued well to the present time.

Series 15.-On March 30, 181)4.45 r. r. of the condensed fuid had been collected from the breath of a healthy person. "lis was again warmed to $35 \mathrm{C}$, and injected into the perituneal cavities of four rablits, each receiving to c. c. of the liuid ; their weights were as follows: 1161 $\mathrm{g}$, $1359 \mathrm{~g}, 1400 \mathrm{~g}$. and $1759 \mathrm{~g}$.

On November 2,1894 , the rabluts of this series having remained healthy, Lios, 2 and 3 were killed in order to stucly the condition of their organs, and determine whether they presented organic lesions traceable to the fluirl injected. They were in perfect healch as far as might be jurlged from their appenances.

(I) post-mortem examination all the organs in these animals were found to be normil. Nor was any abnormality to be noter in microscopic examination of the organs.

The remaining animals of this series continue well to the present time.

The pathological conditions noterl in the cases of rabhits Nos, 1 and 3 of Series 111 .. are not unusual in these aninals, as they are very commonly found in normal animals reared in the lilloratory and in those purchased from dealers. ${ }^{*}$ It is unsafe to infer, therefore, that any of the conclitions noterl in these animals were due to the action of the fluid injected.

The sterility of the fluid injected into the animals in this series of experiments wits testerl each time ly the inoculation of portions of it into tubes of meltex gelatin: these were then hardened accordin: 10 Fomareh's methexl. In two instances several colonies of a yellow bacillus, common to

* This fact has also heen noted by Ir. Abbult. Itisolsecrvations have nol get been published. 
the air of the laboratory, developed in the cultures. In the other instances the cultures remained sterile. The fluid used in these cultures was taken from the portions remaining after the animals were inoculated. This fact, in all probability, accounts tor the contaminations noted. There is no evidence that any micro-organisms were carried over in the exhaled breath while collecting the Huids for the inoculations. The nature of the organisms whith developed in these cuttures indicates that they gained entrance to it while the fluic was being warmed and inorulated into the animals.

VII.-Experiments causing animals to breathe air recently expired by other animals.

"These experiments are designated as "Brown-Séquard" experiments. The apparatus used consists of a series of bell jars, four to six in number, connected together by means of glass and rubber tubing, and so arranged that a continuous current of air is conducted through the entire series. The apparatus is shown in Fig. 8 . The first animal receives pure air only, the second

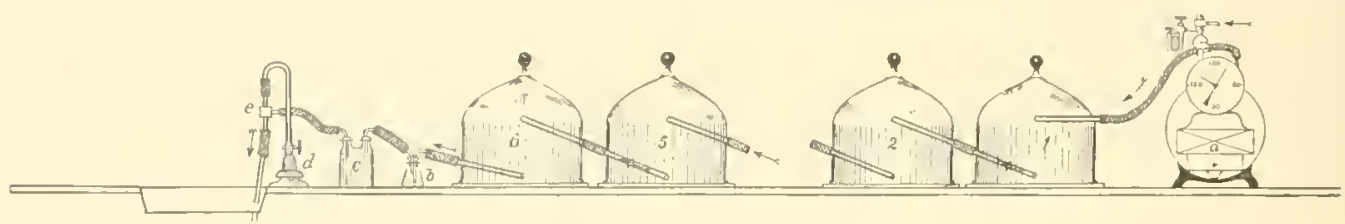

FIG, 8.-Brown-séquard apparatus.

animal receives the air coming from the bell jar containing the first animal, the third that coming from the second, while the last animal receives air that has traversed the entire series, and, consequently, contains the impurities added to it in its course through all the other jars.

THE "BROWN-SÉQUARD" APPARATUS-FIG. 8.

The Nos. 1, 2, 5, 6 represent four of the six bell jars in the series.

$a$, represents the gas meter.

$b$, represents a small Erlenmeyer flask containing about $100 \mathrm{c}$. c. of water. The bubbles produced by the air passing through the water show whether aspiration is regular or not.

$c$, represents a Woulf bottle attached between the Erlemmeyer flask and pump to prevent the entrance of water into the appraratus when there is negative pressure in the apparatus.

$d$, represents the water tap.

$e$ represents a Chapman water pump, which creates the suction and maintains the ventilation.

The glass and rubber tubing connecting the different parts of the apparatus, as shown in the figure, has an internal diameter of nine mm., while that used to connect the seven-litre bell jars was only five mm. in its internal diameter.

$$
\text { 1)ESCRIPTION OF THE "BROWN-SÉQUARD" APPARATUS-FIG. S. }
$$

The bell jars rest on large ground-glass plates, and, in order to produce an air-tight joint, the base of the bell jar is well rubbed with beef suet (well adapted for this purpose). In addition to this, the joint is sealed with melted paraffine. If this work is carefully done there is no possibility of leakage at these joints. The bell jars are connected together by means of glass tubing bent at right angles and inserted through a perforated rubber cork fitted into the openings near the top and bottom of the jar. The air enters the apparatus throngh the gas-metre. The metre is connected with the first jar by means of rubber tubing attached to the glass tube inserted into the upper opening of this jar. After passing through this jar it takes its exit by means of the glass tube inserted into the lower opening, and connected with a similar glass tube inserted into the upper opening of the second jar by means of a short piece of rubber tubing. It takes the same course through all the jars.

The bell jars shown in the figure represent those used for the rabbits, and have a capacity of 37,000 c. c. A wooden box, four inches in depth and just large enough to allow the bell jar to be 
placed over it, was placed in each of these hell jars. These boxes contained fine dry sawdust to a depth of about five cm., thus forming a comfortable bed for the animals, and at the same time absorbing the urine. In the hast experiment (No. 33) it was found necessary to change the sawdust in these hoxes every eight to twelve days. When the sawdust was changed cacla weck the animals remained comfortable.

The bell jars used for the mice, sparrows, and guinea pigs were exactly similar in construction to those represented in the figure, but only of $7000 \mathrm{c}$. c. capacity. For these animals a talse bottom of wire netting was placed in the bell jars instead of the boxes with sawdust. This arrangement served to keep the mice and sparrows dry and comfortable, but was less saticfactory with the guinea jigs.

For the mice and sparrows sufficient food and water were placed in the jar at the beginning to last to the close of the experiment. For the guinea-pigs and rabbits this was impossille ; these being fed daily on cabbage leaves introduced through one of the openings in the jars. liy arresting the aspiration of air through the apparatus for a few minutes there was iery little opportunity for any change to take place in the confined air while the animals were being fed.

In order to faciliate the taking of samples of air from the bell jars, a 'T-tulue was inserted between each of the last three jars. The liunte gas-burette was attached to the stem of one of these T'tubes and the air aspirated from the jar lyy the force of the water flowing out of the lower open. ing of the burette. By placing a serew clamp on the rubber connections on either side of the T-tube it was possible to take a sample of air from the jar before or after it, as might lee desired. l3y stopping the aspirating pump there was rarely any difficulty in taking a sample of air from any of the jars in the manner stated. On two or three occasions a slight negative jressure in the jar, cansed by the small amount of ventilation thking place, prevented the aspiration of a sufficient amount of air (roo to $150 \mathrm{ccc}$ ) to acromplish its analysis in the burette. Wherwise no trouble was experienced in the taking of samples of air as desired. The gas-burette was connceted with the T'tulues by means of a short piece of rulbler tubing attached to the stem of these tubes and ordinarily closed with a short glass rod. 'The rubber tubing was attarhed to the three-way stopeock of the burette.

The results in the thirty-three experiments performed upon sparrows, mice, guinea pigs, and rabbits are shown in the following tables.

In these experiments, as well as in those previously reported, the disturbance of the heat-regulating function may have contributed to the results.

Absorbers containing caustic soda or potash, or soda lime, were used in experiments 6 to it between the third and fourth, and the fourth and fifth jars of the series to alsorl, the ( $\mathrm{O}$. from the air passing into the last two jars. T'his arrangement failed to save the lives of the animals in these two jars. In experiments 15,18 , and 19 , an absorption-tube containing concentrated $\mathrm{H}_{2} \mathrm{SO}_{4}$ was placed between the last two jars. The results obtaineel in these three cxperiments do not differ from those obtained without the $\mathrm{H}_{\mathrm{g}} \mathrm{SO}$, absorbers, and, therefore, give no evidence whatewer of the protective infuence claimed for such absorbers. The primary cause of death, low percentage of $O$, was still present and active.

Experiments 20 to 28 were made with the hope of producing some slight folerance to the atmospheric conditions present in these experiments on the part of an animal subjected to such conditions for a considerable time. While there is positive evidence that a mouse living under these conditions for several day's can withstancl an atmosphere that instantly kills a fresh mouse, the number of experiments made are insufficient to prove that such tolerance has any great degrec of permanency; yet the results obtained with the mice carried through the series of experiments from 20 to 28 indicate the probability that the tolerance obtained is maintained for at least several days afterward, and that such animal is less likely to die when again quickly placed inte such an atmosphere than one that had not had such an experiente.

The guinea-pigs used in experiment 30 secmed to be unable to withstand, with equal facility with the nice and sparrows, the atmospheric conditions to which they were subjected. Several if them succumbed to cedema of the lungs during the second week of the experiment, but sinec this 
is the only experiment in which these animals were used, a positive opinon on this point cannot be given.

The rabhits in experiment 3 i were supposed, at the time, to have succumbed to the oppressive heat of the lahoratory owing to the season of the year, lut the later experiments would indicate an insufficient amount of air was aspirated through the bell jars, and it is evident that leakage took place through some of the connections because of the irregular order in which death touk place.

The last exporiment was made to determine what the results would be when the proportion of CO. was kept as low as lirown-Sequard and d'Arsomval ("laim for their experiments. It was found impossible to aspirate sufficient air per hour to bring about this result. However, sufficient air was aspirated to prevent the reduction of the $O$ to proportions that were insufficient to support life. Bi this means it was posible to continue the experiment for six weeks without losing any of the animals, or proslucing any grave symptoms in any of them.

In this experiment mercurial manometers were attached between the first and second, and between the fifth and sixth bell jars to ascertain the anount of negative pressure, if any, brought about by the conditions or by the form and arrangement of the appratus. A difference of about three millimetres was noted botween the fifth and sixth bell jars, while no difference was noted between the first and second. It as also ascertained, by placing a clamp on the rubber tubing connecting the fifth and sixth jass, and continuing the aspiration, that the amount of negative pressure repuircd to break one of the glass plates on which the jars rested, as arcurred in experiment 32 , was 105 mitlimetres. From this it may be inferred that at times a greater negative pressure existed than that noted in the last experiment. Such extreme negative prcssure as was found necessary to break a glass plate $45 x+5 \times 0.6$ centimetres conld only occur upon the entire arrestation of the air-current from somz arciclent to the apparatus. Under ordinary circumstances we do not believe that the amount of negative pressure differed to any extent from that found in the last experiment.

The proportions of $\mathrm{CO}_{2}$ and of $\mathrm{O}$ present at the time of death bear a constant relation to each other in the different experiments. The duration of life in each instance was dependent entirely upon the rapidity of the air current circulating through the apparatus. This statement, however, requires further explanation. If the average rate of ventilation per hour for an entire experiment is taken, it will lie found to vary considerably in the different experiments. This is evident when it is stated that in experiment 7 the rate had been 9.8 litres per hour up to the time of the death of the animal in the third jar; in experiment 8 the rate had been 3.8 litres per hour at the death of the fifth animal; in experiment 9 the rate had been 1 .g litres per howr at the death of No. 5; at the death of No. 3, in experiment 14.102 litres per hour; at the death of Nos. 3, 4. and 5 , in experiment 15.3.45 litres per hour; at the death of Nos. 3 , 4 , and 5 , in experiment 16 , only 1.9 litres per hour; at the death of $\mathrm{N} n 5$, in experiment $19,3.55$ litres per hour. From these figures it will be seen that the average rate of ventilation per hour for an experiment is not the most important factor. liy referring to the tables giving the details for each of the 33 experiments it will be roted that the rate of ventilation was frequently changed. It was usually increased considerably in the evening and again decreased the next morning Frequent changes in the rate during the day were also necessary, because it is practically impossible to get a perfectly steady current with the water pump. In carefully regulating the rate of ventilation, the lives of the animals were controlled at wll, and it is upon the rapidity of the air-current toward the close of the experiment that the duration of life depended in each case.

The rabbits used in the last "Brown-Séquard" experinent were weighed at the end of the experiment and their weight then as compared with their weight at the beginning of the experiment was as follows :

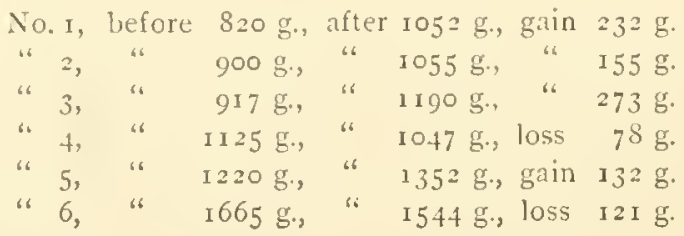


At the death of No. 4 , -ix days after the close of the experiment, the loss in us weight was found to have been caused by the presence of psurosperms in ts liver. This organ was liferalls filled with masses of these bodies. The loss of weight in No. G, in the ahsente of an other observable exuses, maly be safels attributcel te its position in the series of bell jas, and, theretore, to the imprity of the atmosphere which it breathed. The estimations of the propurtions of (') and of (1 present in this bell jar, as found trom day to day, denote atmospheric condutions that were undoubledly unfavoralie to the full performance of its bodily functions. Le ate less ravenously than the other animals and was frepuently in a stupid, drowsy condition

At the close of this experiment an examinatton of the blood of these rablits was also made and the proportion of cormuscles per cubic millinetre determined with the Thoma Keins hamo. cytomeler, with the following results:

\begin{tabular}{|c|c|c|c|c|c|c|c|}
\hline 2. $5,337,000$ & “ & ". & 21.000 & " & “ & “6 & ". \\
\hline $3,+, 510,000$ & " & “" & 18,000 & " & " & "4 & "6 \\
\hline $4,4,150,000$ & “ & $" 6$ & 10,000 & “" & " & 2 & “ \\
\hline 5. $4,950,000$ & “" & $"$ & 15.000 & " & "6 & "“ & “ \\
\hline $6,+.375,000$ & “ & “ & 16,000 & " & $"$ & “ & $"$ \\
\hline
\end{tabular}

Here again there is evidence that the conclitions evisting in these bell jars were injurious to sonce extent; most so in the last jars. No. tpresents evidence of an influence more serious in its nature than that presented by the other animals, and this has since been found to bave originated from causes within its own bodr.

Microcytes were noted in the blood of these animals. These immature corpusches secmed to be more numerous in Nos. $t, 2$ and 1 ; the blood of the other animals presenting only a few of these bodies.

Thirty-eight days after the termination of the experiment a second cxamination was made of the blood of the five remaining animals, witls the following resuits:

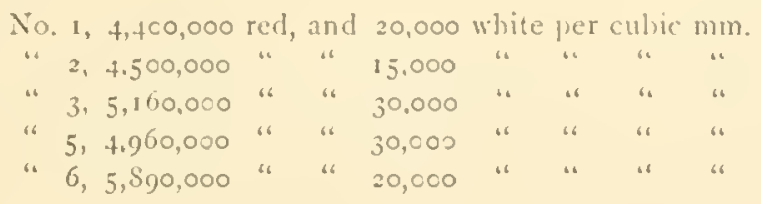

The first and second animals show a slight reduction and the third and sixth an increase in the number of corpuscles. No mirrorytes or blork-phlates were no iced this time.

The weight of these animals at the time of this second examination of the blood was as follows :

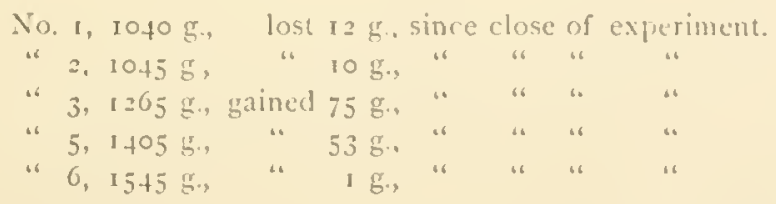

The loss of weight in the first and second animals may be due we the change of food. The gatin in the others is no doubt due to the better atmosphesic conditions under which thay are now living. 
Post-mortcm examinations of a number of the animals dying in the "Irown-Sépuard " experiments were made with the greatest care. The organs were preserved in alcohol and mounted in celloidin for the microscopic examination. 'l'he gross appearances presented by the animals showed a constant similarity to the appearances noted in the animals used in the experiments with artificial gaseous mixtures. The constint appearances noted were those of intense venous engorgement of all the organs and tinstes. 'The heart cavities contained firm, dark clots of blood, filling both auricles and ventricles, those on the right side being usually much larger than those on the left. No infammatory changes or serous exudates were found in any instance.

Microscopic examination of the organs presented no constant feature aside from the manifestations produced by the cause and mode of death. Fingorgement of the blood vascular system was noted every where with usually some degree of infiltration in the lung. No degenerative changes were constantly present. Those found in isolated cases-such as a slight increase of connectivetissue elements between the tubules of the kidneys and about the glomeruli, and small areas of prolifuration of connective-tissue elements in the liver-cannot be safely attributed to the experiment. This opinion is strengthened by the short duration of the experiments, and it is probable that the changes were lue to ante-experimental causes.

The node of death as observed in these experiments presented certain constant features which were undistinguishabte from those produced by slow asphyxia under other circumstances. There was a period of excitement, followed, in the course of time, by a period of progressive depression. The breathing, at first rapid, generally became slower, with perceptible lengthening of the respiratory pauses, accompanied at a later period by marked expiratory efforts. Along with these respiratory changes was usually noted a progressive muscular weakness gradually deepening into paralysis of the posterior members. The animal moves about with evident difficulty, and finally sinks down, remains lying on the side or back, without any other movements than those of respiration. It now presents a comatose condition from which it cannot be aroused by striking the sides of the lell jar. l)eath usually ensues through the gradual lengthening of the respiratory pauses passing into an entire failure of respiration. In a small proportion of the cases, life becomes extinguished through one or two convulsive seizures.

\section{No. I. TROWN-SÉquard EXPERIMENT.}

Commenced at 5 P.M., March 2, IS94. Sparrows in I litre flasks. 4 in series.

The + mark indicates the deatli of the animal.

\begin{tabular}{|c|c|c|c|c|c|c|c|c|}
\hline \multirow{2}{*}{ Time. } & \multicolumn{2}{|c|}{ No. I. } & \multicolumn{2}{|c|}{ No. 2.} & \multicolumn{2}{|c|}{ No. 3 . } & No. 4 . & \multirow{2}{*}{ Remarks. } \\
\hline & $\mathrm{CO}_{2}$. & o. & $\mathrm{CO}_{2}$. & o. & $\mathrm{CO}_{2}$ & O. & $\mathrm{CO}_{2} . \quad \mathrm{O}$. & \\
\hline $\begin{array}{l}\text { I7: brs } \\
17 \frac{3}{4} \text { "6 } \\
18: " 6 \\
19 \frac{1}{4} " 6\end{array}$ & & & & & & + & & $\begin{array}{l}48.5 \text { litres aspirated each } \\
\text { hour; too rapid. } \\
\text { Changed to } 2.85 \text { litres per } \\
\text { hour. } \\
\mathrm{No.} 3 \text { died. Symptoms } \\
\text { of } \mathrm{CO}_{2} \text { poison. } \\
\text { Experiment stopped. }\end{array}$ \\
\hline
\end{tabular}




\section{No. 2. BROWN-SÉQUARD EXPERIMENT.}

Commenced at 1 I 45 A.M., March 3, IS94. Sparrows in 7 -litre bell jars. 5 in serles.

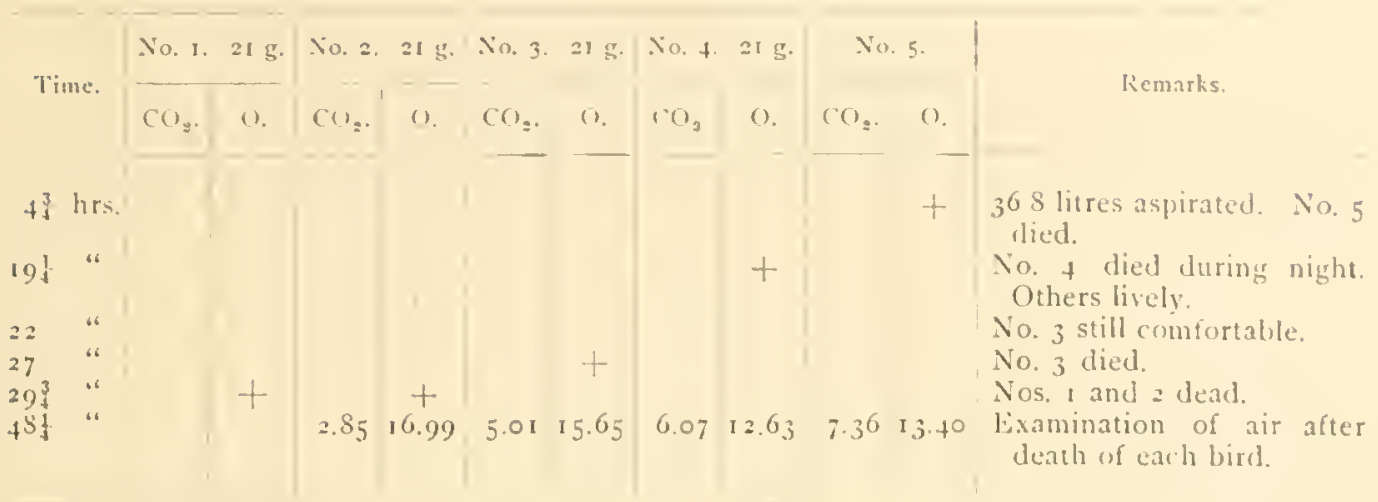

No. 3. BROWN-SÉQUARD EXPERIMENT.

Commenced at $12.15 \mathrm{l} \mathrm{M}$., March 5,1 S94. Sparrows in 7 -litre bell jars. 5 in series.

\begin{tabular}{l|l|l|l|l|l|l|l|l|l|} 
\\
Time.
\end{tabular}

No. 4. Brown-Seguard Experiment

Commenced at 9.30 A.M., March 7,1894 . Sparrows in 7 -litre bell jars. 5 in series.

\begin{tabular}{|c|c|c|c|c|c|c|c|c|c|c|c|}
\hline \multirow{2}{*}{ Time. } & \multicolumn{2}{|c|}{ No. $1.2 \mathrm{lg}$. } & \multicolumn{2}{|c|}{ No. 2. $22 \mathrm{~g}$. } & \multicolumn{2}{|c|}{ No. 3. $23 \mathrm{~g}$} & \multicolumn{2}{|c|}{ No. 4. $25 \mathrm{~g}$. } & \multicolumn{2}{|c|}{ No. 5. $21 \mathrm{~g}$. } & \multirow{2}{*}{ Remarks. } \\
\hline & $\mathrm{CO}_{3}$. & o. & $\mathrm{CO}_{\mathrm{s}}$. & o. & $\mathrm{CO}_{2}$. & o. & $\mathrm{CO}_{2}$. & o. & $\mathrm{CO}_{3}$. & O. & \\
\hline $13 \mathrm{~h}^{3} \mathrm{hrs}$ & & + & 14.30 & $4.48_{5}$ & 1401 & 3.635 & & + & & + & $\begin{array}{l}\text { Ill the birds are dearl. No } \\
\text { record of amount of air } \\
\text { aspirated. } \\
\text { Examination of air after } \\
\text { death. }\end{array}$ \\
\hline
\end{tabular}


NO. 5. BROWN-SIQQUARD EXPERINIINT.

Commenced at 6 P.M., March 8,1894 . Sparrows in 7 -litre hell jars. 511 series.

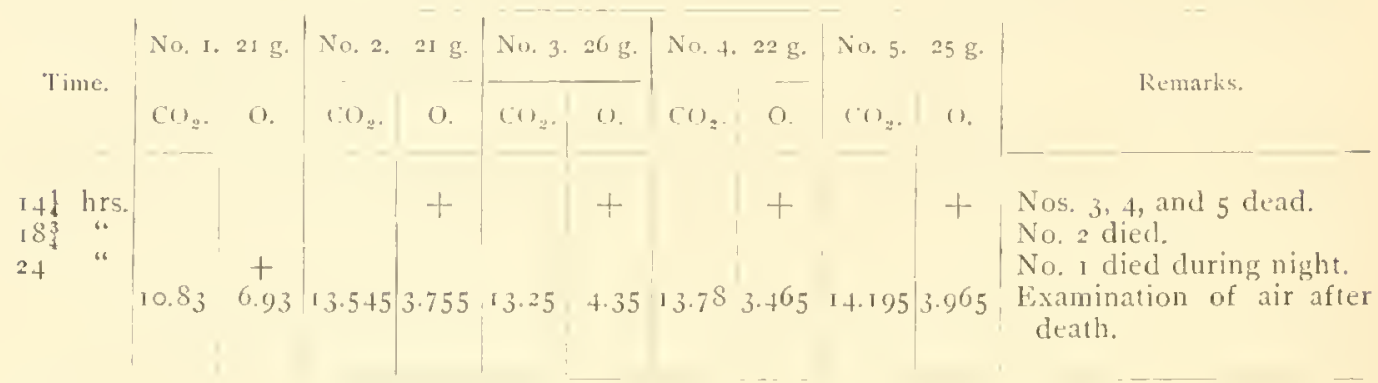

No. 6. BRoWN-SËQUARD Experiment.

Commenced at 8.45 A.M., March 12,1894 . Sparrows in 7 -litre bell jars. 5 in series.

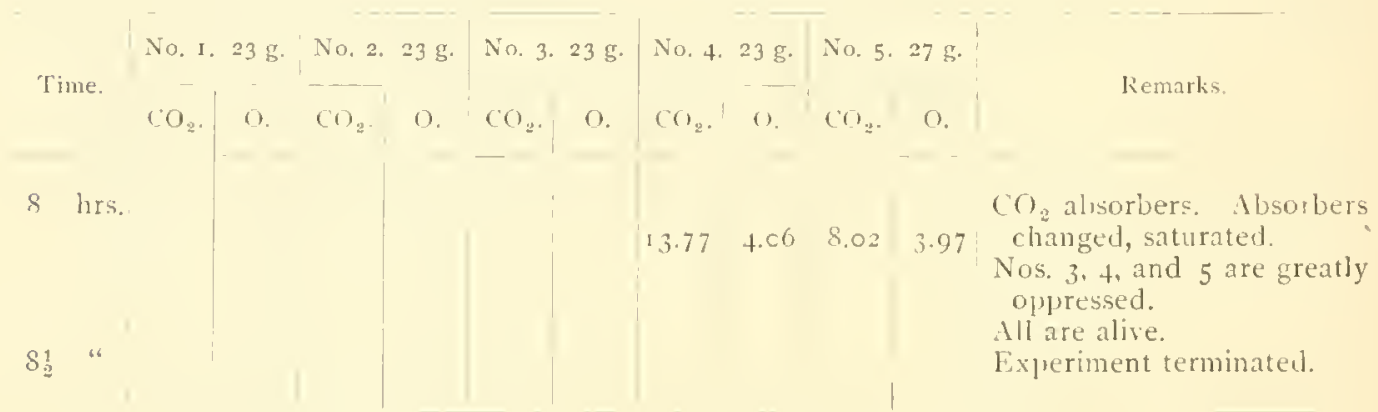

No. 7. Brown-SÉquard Experiment.

Commenced at 915 A.M., March 13, IS94. Sparrows in 7 -litre bell jars, 5 in series.

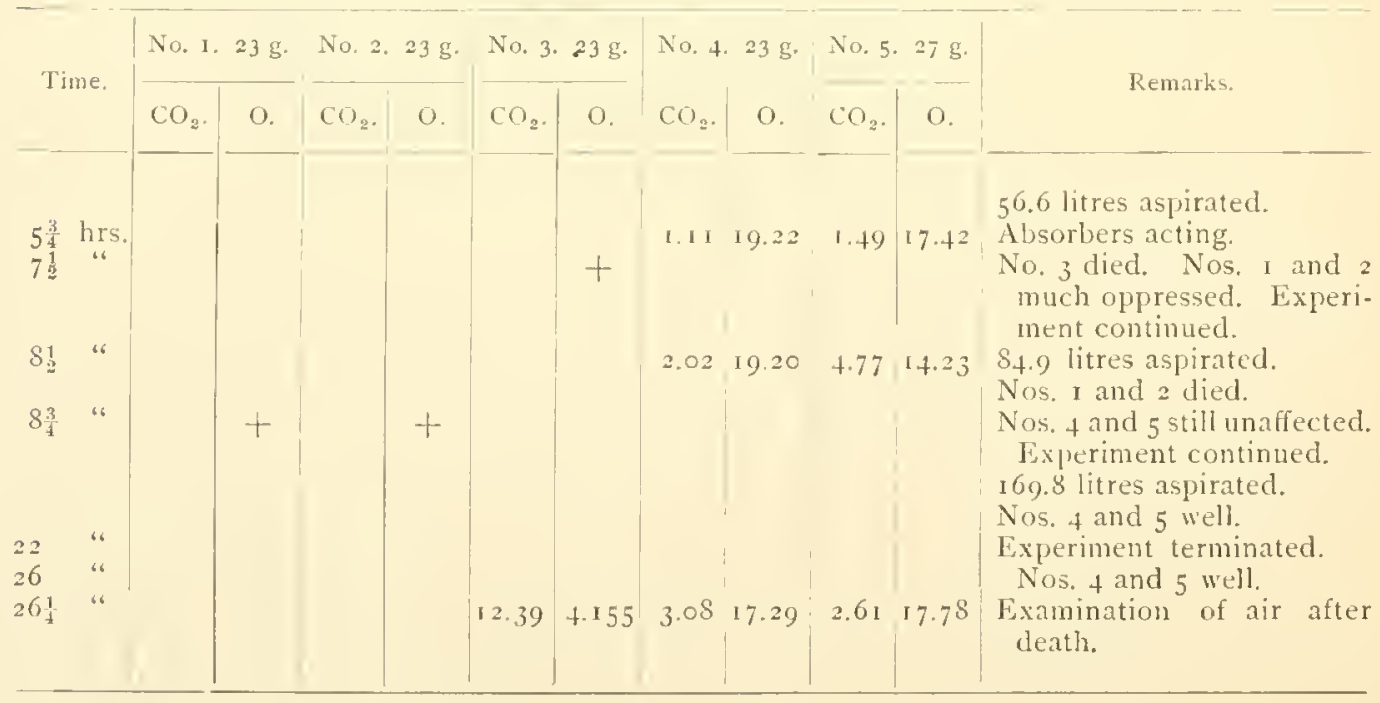


No. 8. BROWN-SFQQARD EXIERIMI:NT.

Commenced at 345 1.M., March 24 , 1894 . Sparrows in 7 -litre bell jars. 5 in serses.

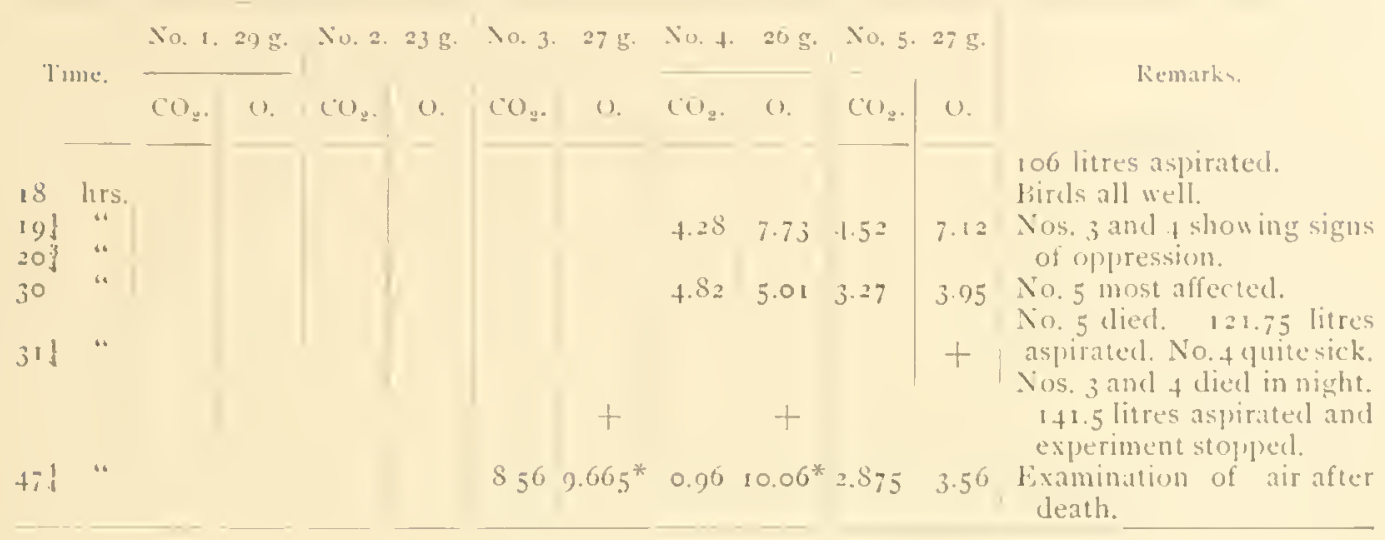

No. 9. IHROWN-SigLARD FXPERIMEXT

Commenced at 11.30 A.M., March 16, 1 S94. Sparrows in 7 -litre bell jars, 5 in series.

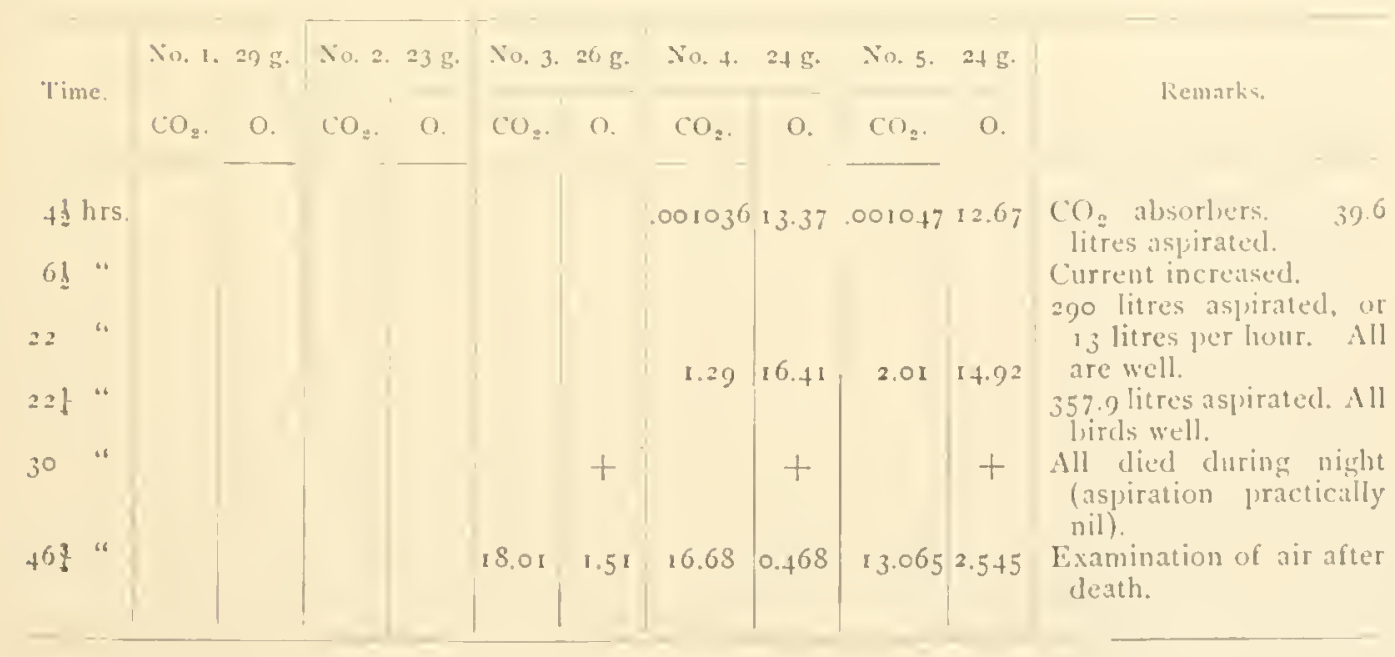

* These air analyses were made several hours after death, and considerable alteration must lave occurted llirough rentilation in the interial. 
No. Io. Brown-ŚEquari Experimint.

Commenced at 9. I5 A.M., March 20, I S94. Sparrows in 7 -litre bell jars. 5 in suries.

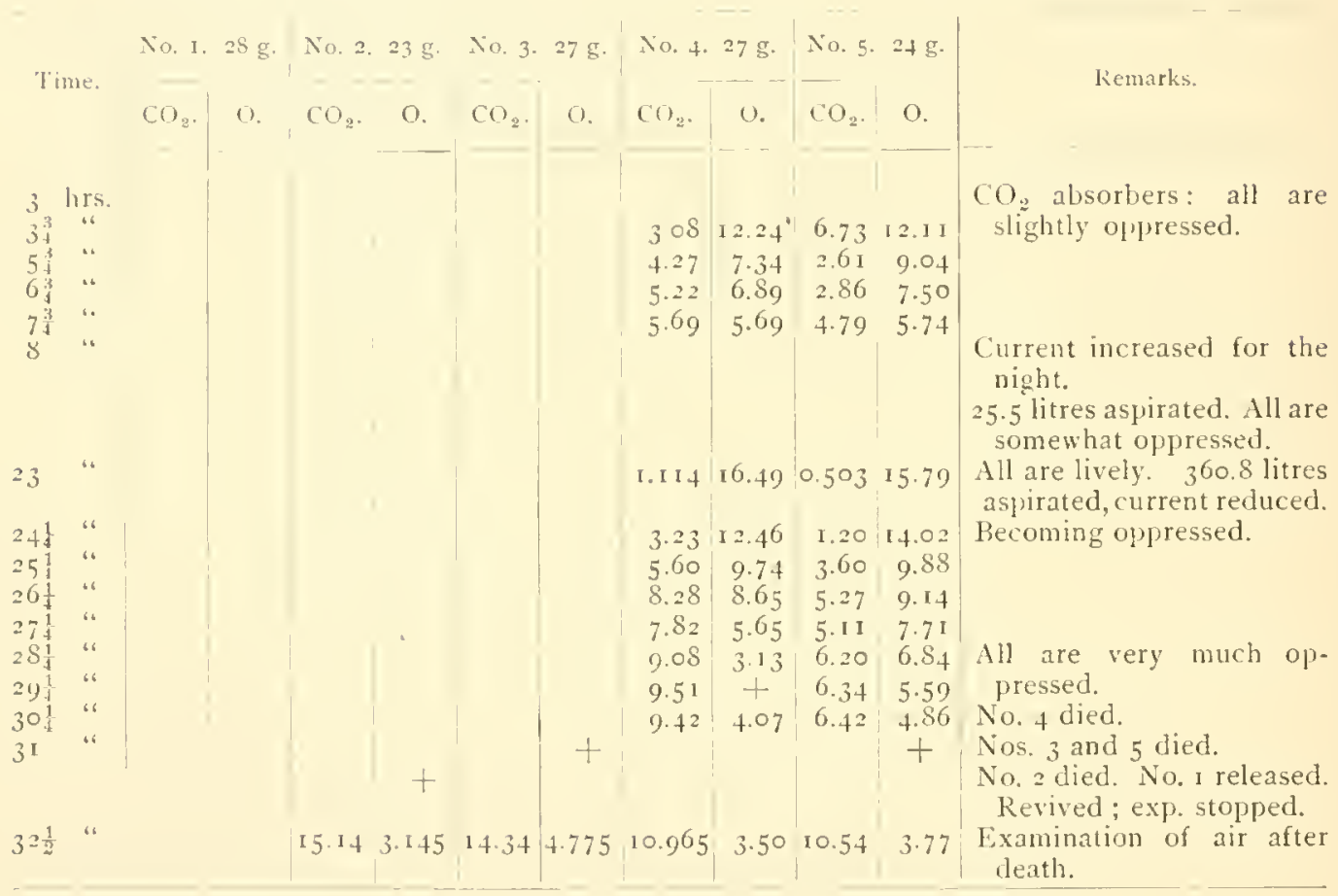


Commenced at I 1.45 A. ., March 22, is 94 . Sparrows in 7 -litre bell jars. 5 in series.

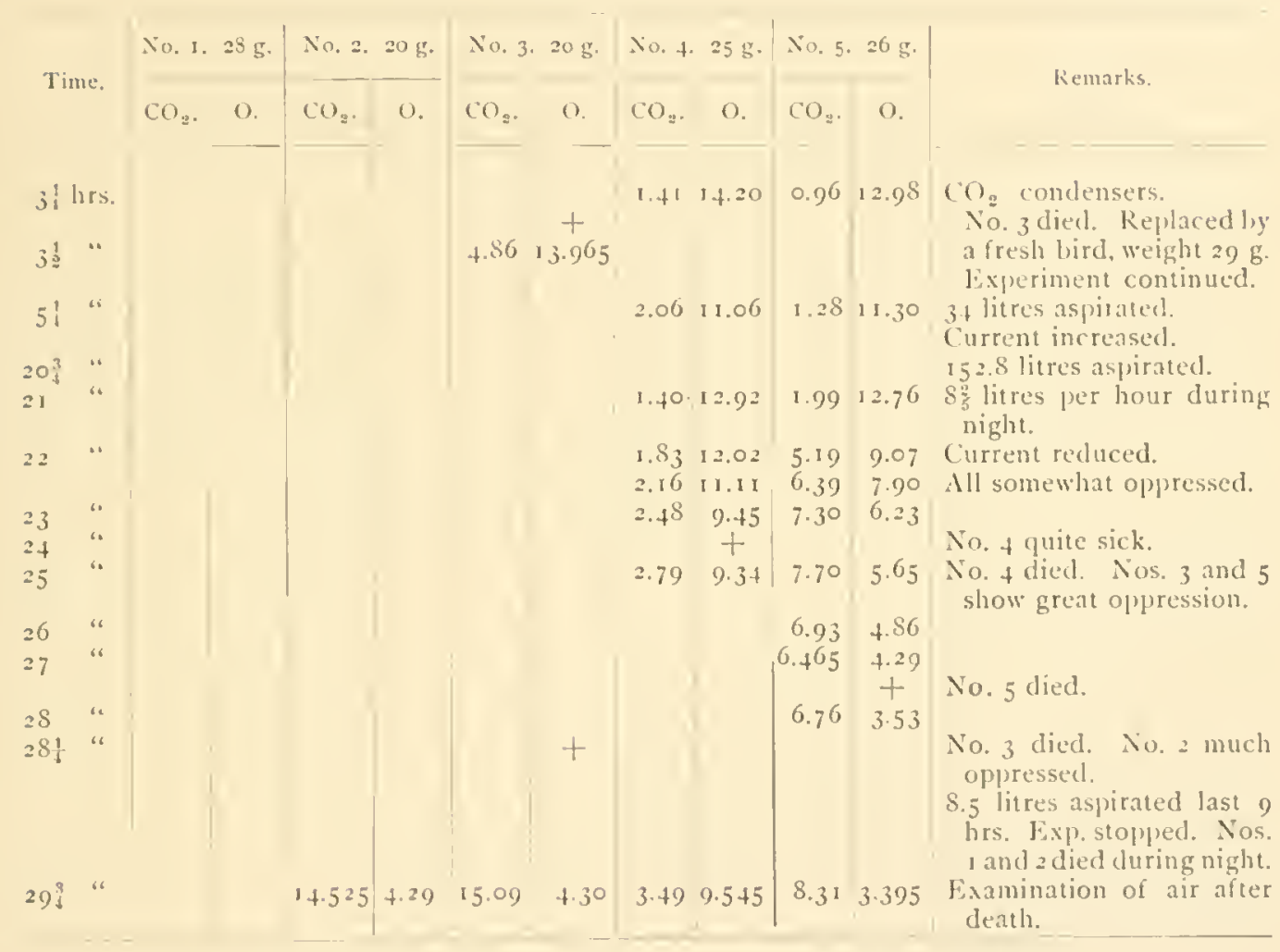


No. 12. BROWN-SEULARD EXPERIMENT.

Commenced at 3.45 P.M., March 24, 1894 . Sparrows in 7 -litre bell jars. 5 in series.

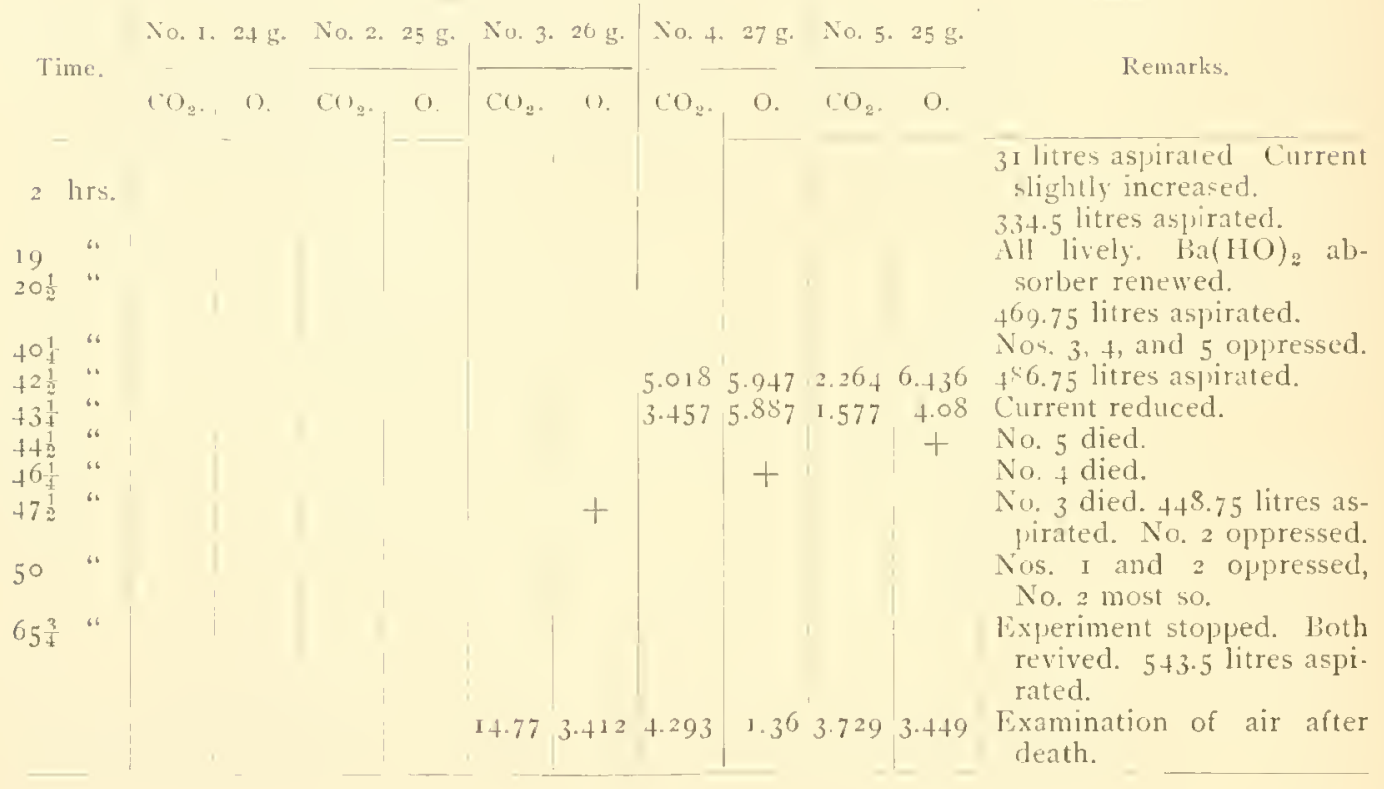




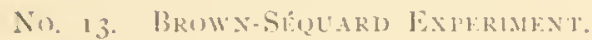

- Commenced at 12.45 p...., .1 arch 27,1894 . Sparrows in 7. litre bell jars. 5 in scries.

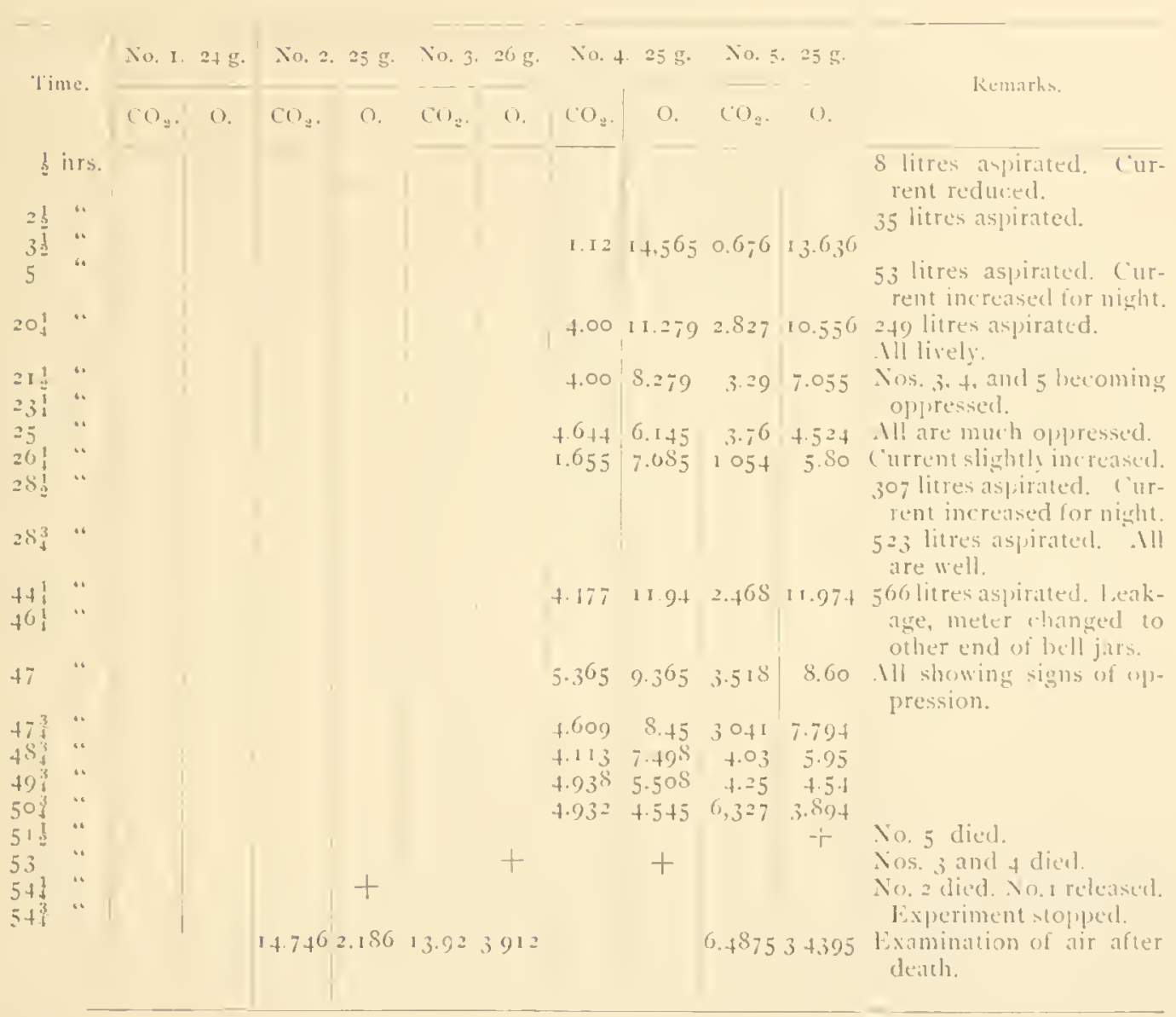


No, 14. BROWN-SEqUARD EXI'ERIMENT.

Commenced at I 2 M., March 30, 1894 . Mice in 7 -litre bell jars. 5 in series.

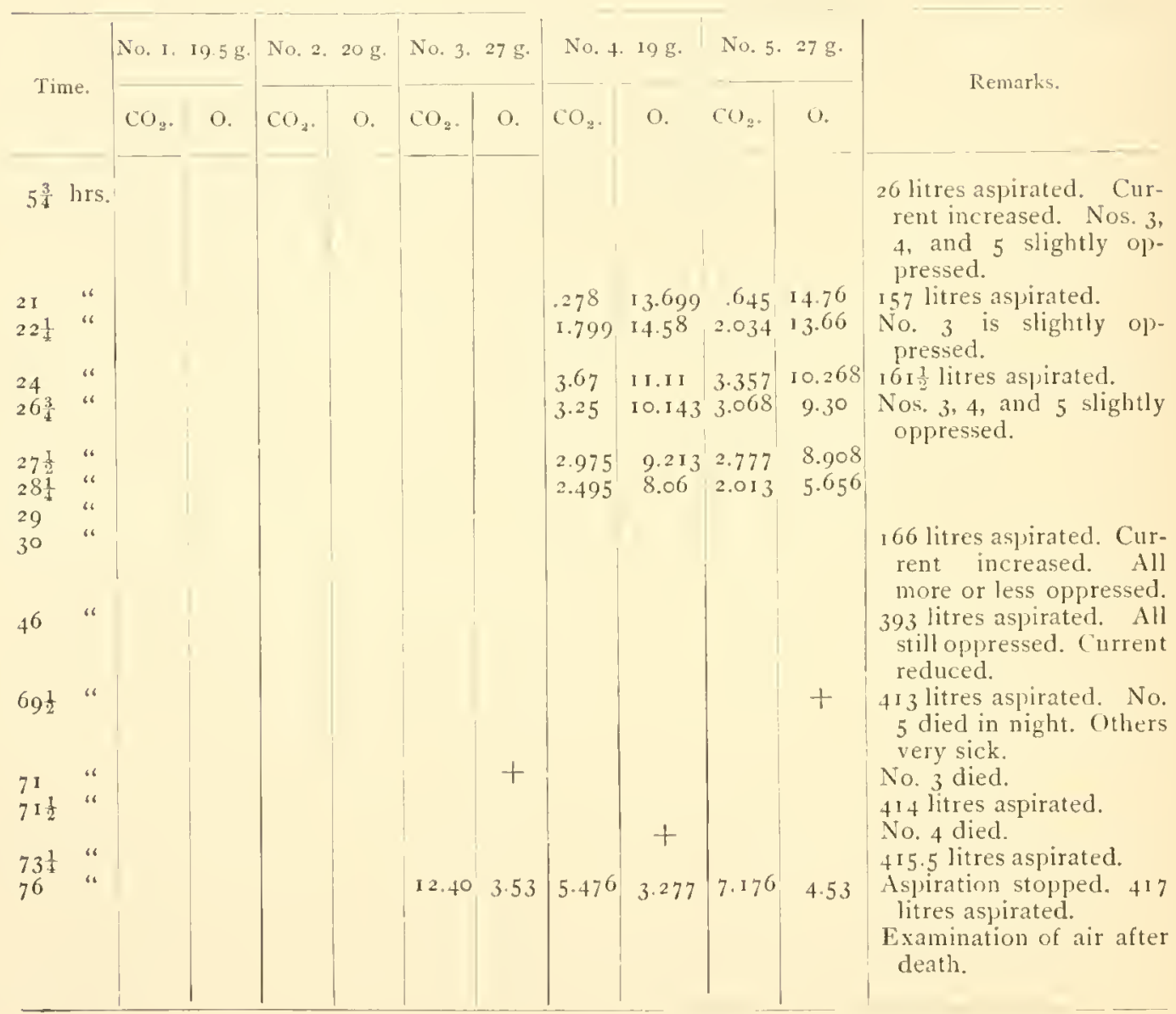


No. 15. BRown-Shound Experiment.

Commenced $12 \mathrm{M}$, April 2, 1894 . Mice in 7 -litre bell jars, 5 in series.

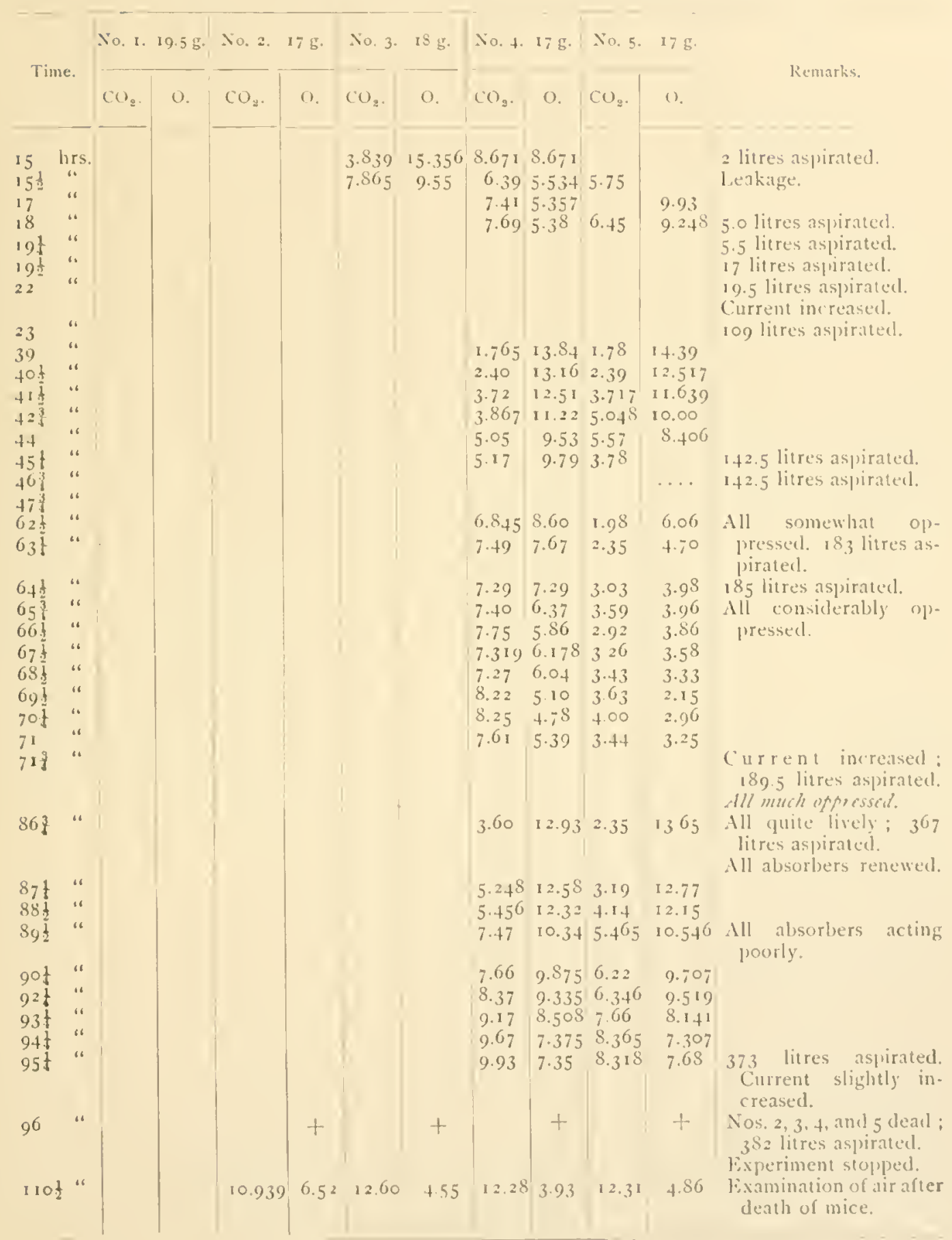


No, I6. BROWN-SÉQUARI EXPERIMENT.

Commenced at 10 A.м., April 9, I 894 . Mice in 7 -litre bell jars. 5 in series.

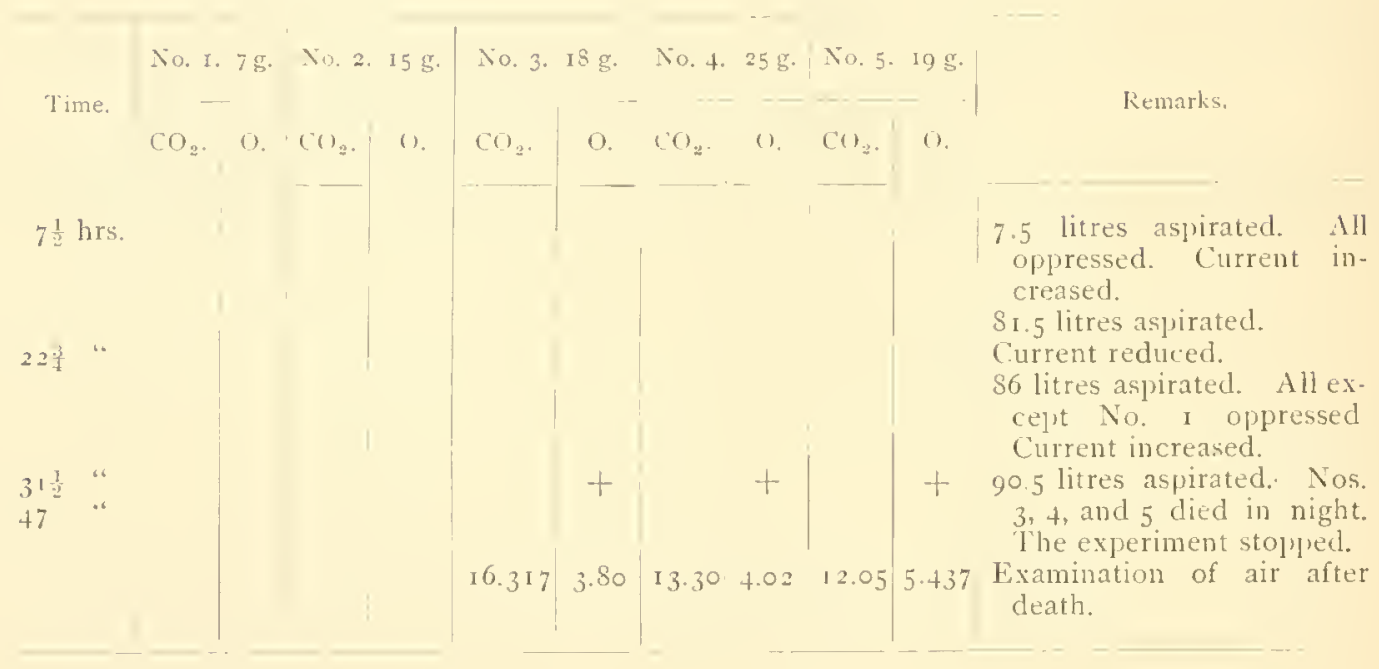


DO. 27. BROWX-SRUUARD EXIERIMEXT

Commenced at $12 \mathrm{M}$. A juril 11,1894 . Mice in 7 -litre bell jars, 5 in serses

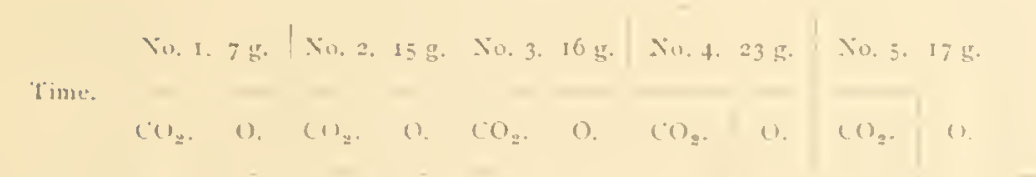

5 hrs

$\therefore \frac{1}{4} \cdots$

30 "

$4+4$

$51 \frac{1}{2}+\frac{1}{2} \cdots$

53

68 -

$\begin{array}{ll}68.3 & . \\ 60 & 1 \\ 71 & . \\ 72 & . \\ 75 & . \\ 76 & . \\ 77 & .\end{array}$$$
68 .
$$

791.

1041 "

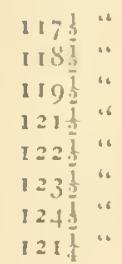

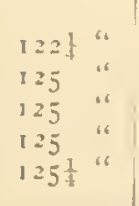
a. Fresh houte misuse placed in To. j jar.
b. " while " " $" .45$ ".
c. .

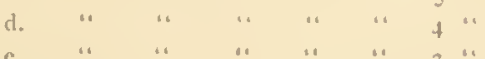
c.
1) texl in $1 w$, minutes.
lived to emel of experment.
liexl in half a minute.
Jied in half an hour.
Lied in six minutes.

1.348 8.80 12.1188 .325 $12.1207 .067 \quad 12.6457 .41$

kemarks

9.5 litres aspirated. .111 slightly oppressed. ("urrent increised.

77 litres atspirated. (current reduced somewhite.

5.35 litres aspirated.

.lil oppressed ; currume again increased.

122.5 litress aspurated ; all lively again.

31.5 litres aspirated. .1l more or less ope presied. (iurrent increised.

179 litres aspirated. All lively again. current considerably reduced.

186.5 litres aspurated. Current increased. II! oppressed.

293.5 litres aspirated. .111 are lively again.

(urrent somewhat reduced for the next 24 hours.

$10.9107 .00 \quad 11.11 \quad 6.536$ $10.9197 .08 \quad 11.73 \quad 7.00$ $11.0686 .25711 .7+5.68$ $\begin{array}{llll}11.11 & 5.465 & 12.535 & 5.22\end{array}$ $12.63+.689 \quad 12.737+9.4$ $12.65+.506 \quad 13.08 \quad .1 .17$ $\begin{array}{llll}12.989 & 4.29 & 13.9^{6} & 3.77\end{array}$

$\int 360.5$ litres aspirated. ill show consideralsle depression.

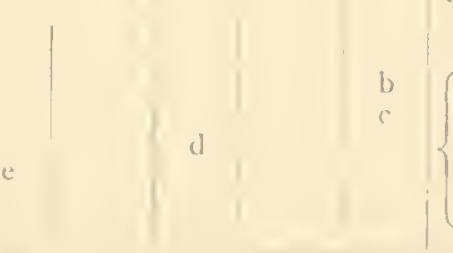

$\left\{\begin{array}{l}x \\ 3\end{array}\right.$

Wiee are much op-
pressed. The ex-
jeriment is now
stopped. Mll revived.
364.5 litres aspirated. 
Commenced at 9.45 A.M., April i 7, 1894 . Mice in 7 -litre bell jars. 5 in series.

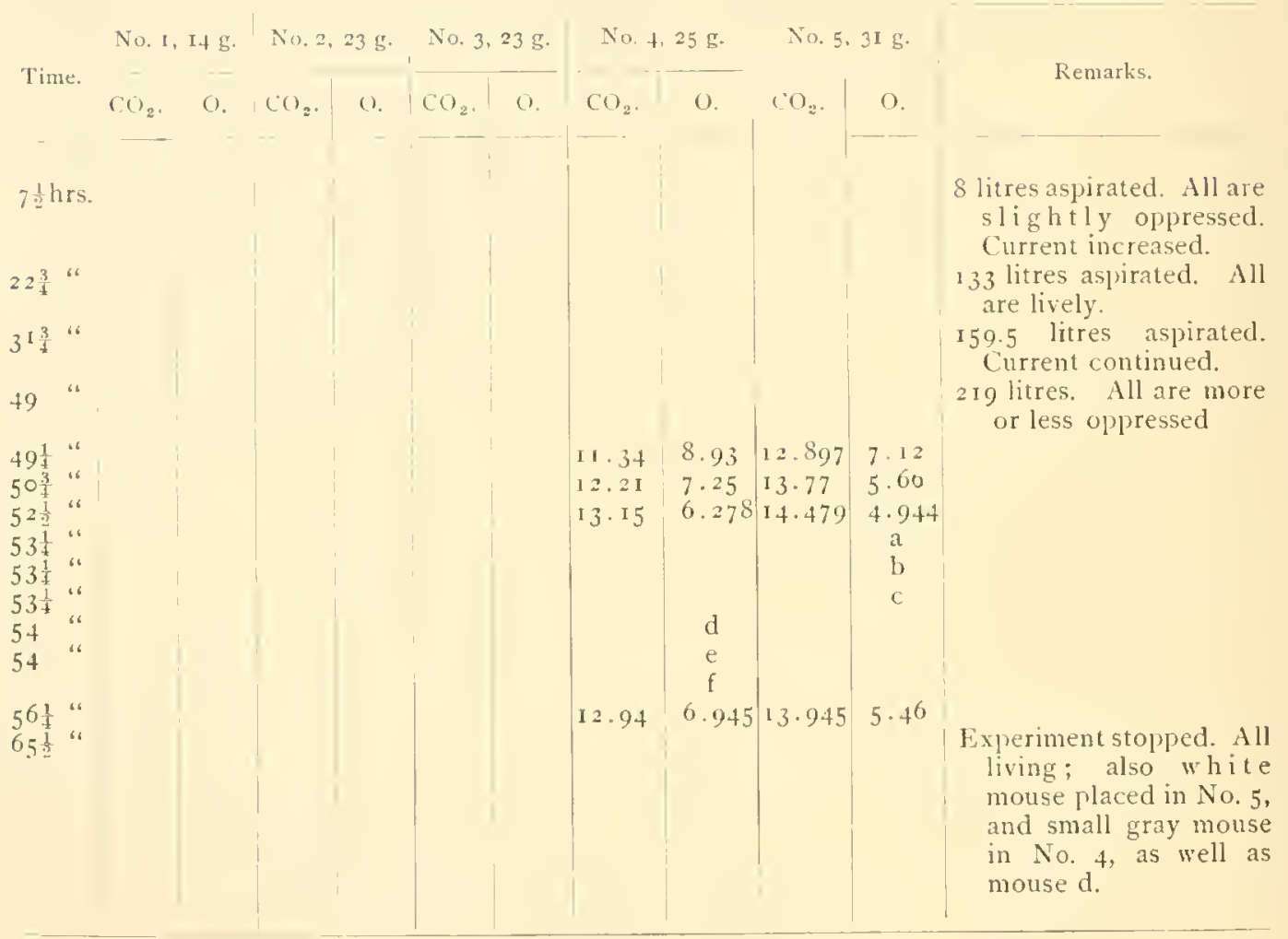

a Fresh house mouse in No. 5 ; died in one minute.

b No. 5 of Experiment 16 in No. 5 ; died in one minute.

c White mouse, used in Experiment 16, in $\mathrm{No} .5$; remained alive to end of experiment.

d White mouse, used before, in No. 4; remained alive to end of experiment.

e House mouse (fresh) in No. 4 ; remained alive to end of experiment.

$f$ House mouse (large) in No. 4 ; died in two minutes. 


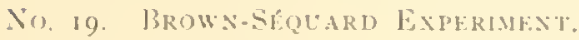

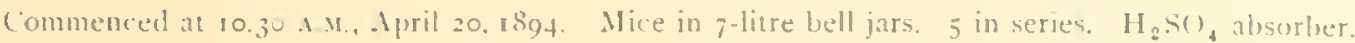

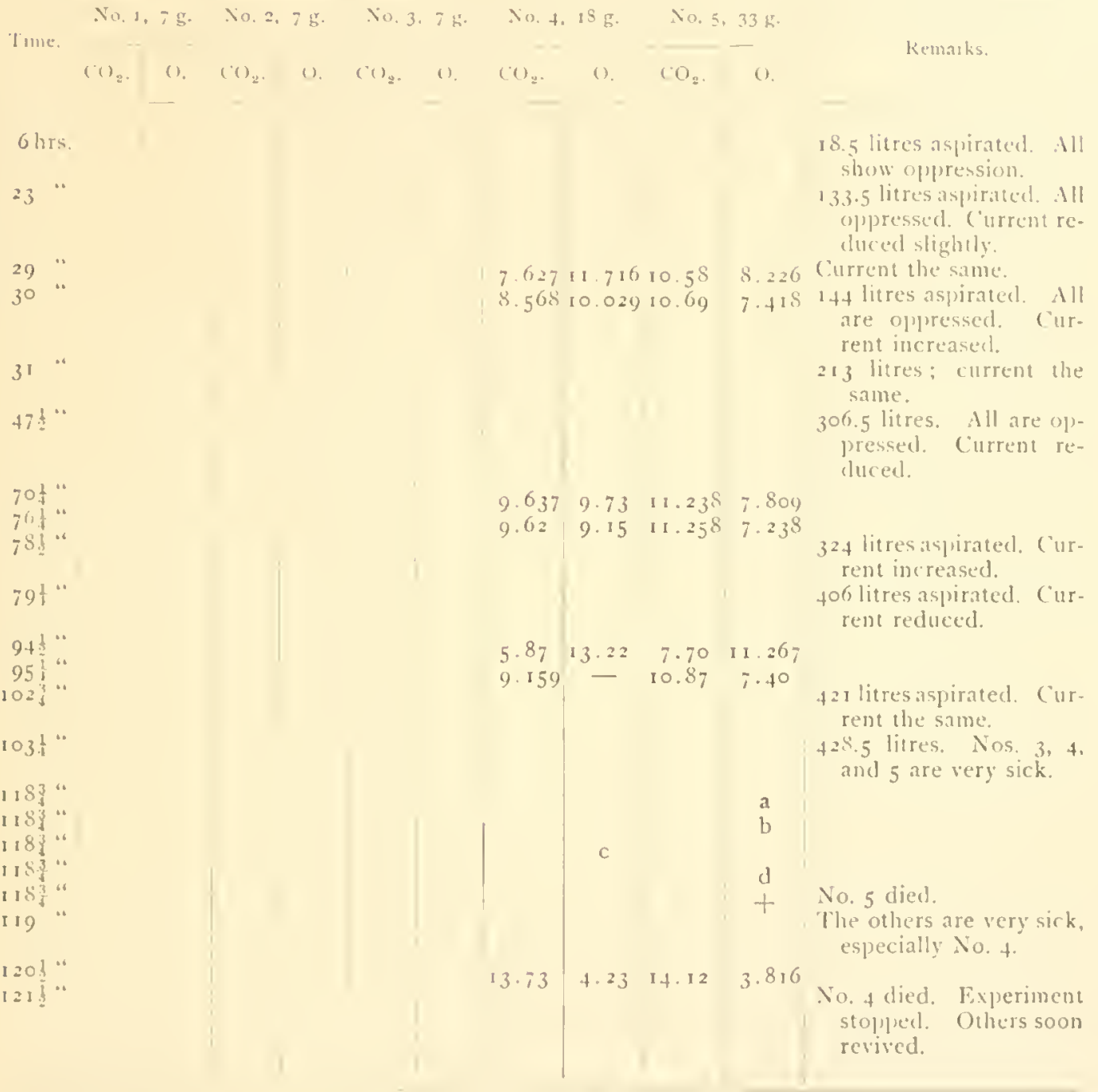

a No. fol last experiment placed in Xio. 5 jar; died in two minutes.

1) White mouse, used in 1:xperiment 1\% placed in No. 5 jar ; died in two and one-half minutes.

c. White mouse, used in lixperiment 17 , placed in $\mathrm{Ko} .4 \mathrm{jar}$; died in three and one-half minutes.

d. Simall mouse, used in Fiperinsent 17 . placed in No. 5 jar; died in one minule. 
Nos. 20-28. BRoWN-SR(zUARI) liXPFRIMENTS.

Commenced at 2.30 P.M., April 25, 1894 ; ended at June 5, 1894 . Nice in 7 -litre bell jars. 5 in series.

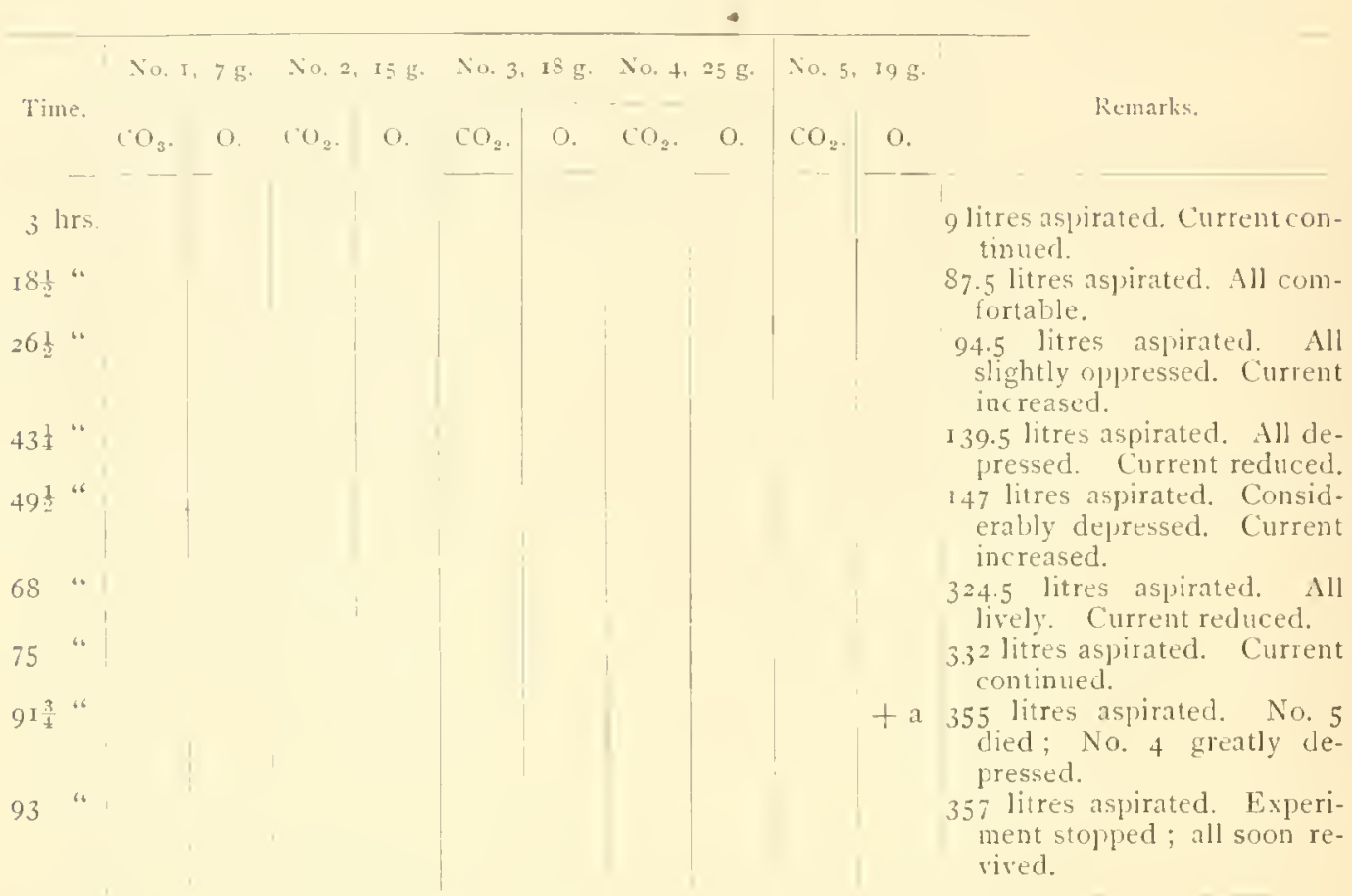

Continued as Experiment 21, after intermission of two days. May 1, IS94.

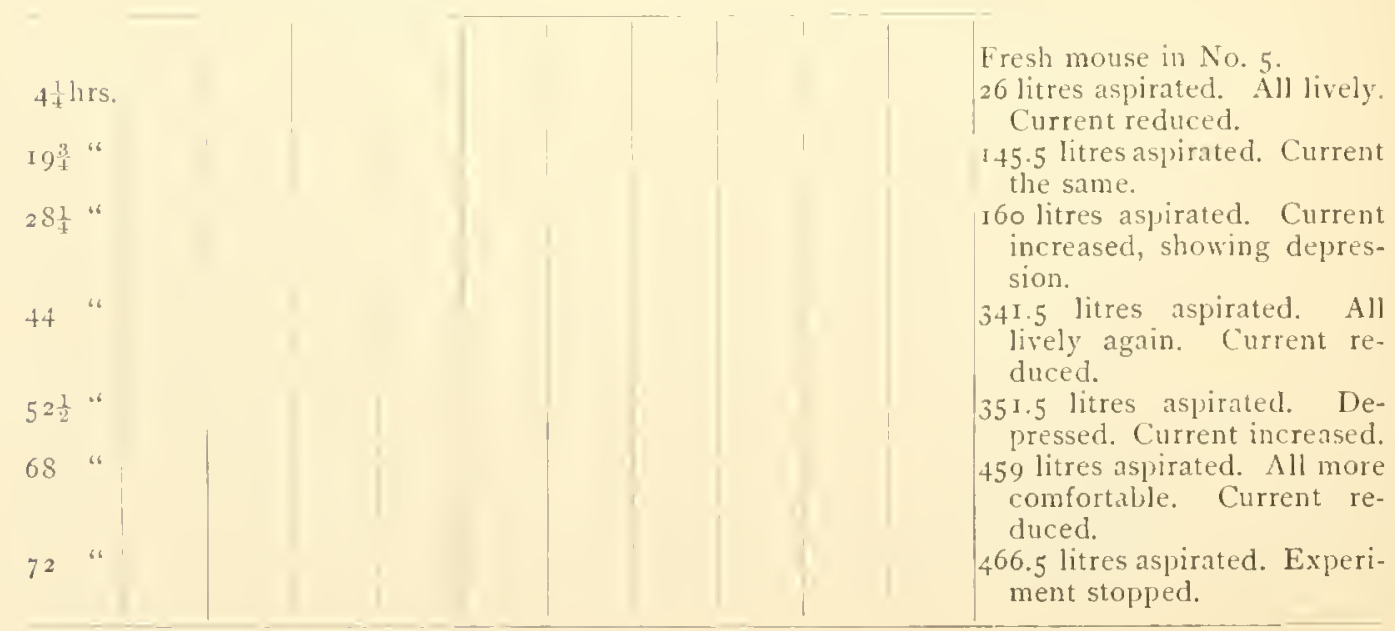


Continued as Experiment 22 , after interval of three days. May $7,1894$.
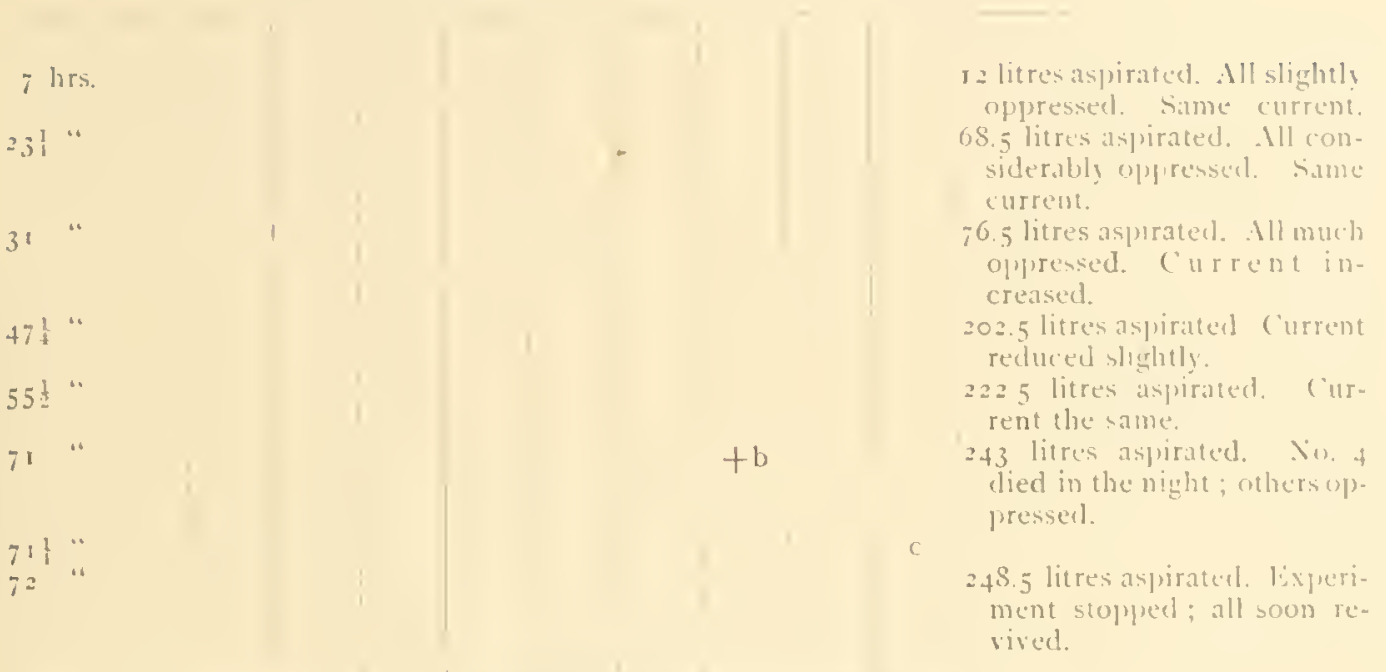

Continued as lixperiment 23 , after interval of three dits. May in, 8.4

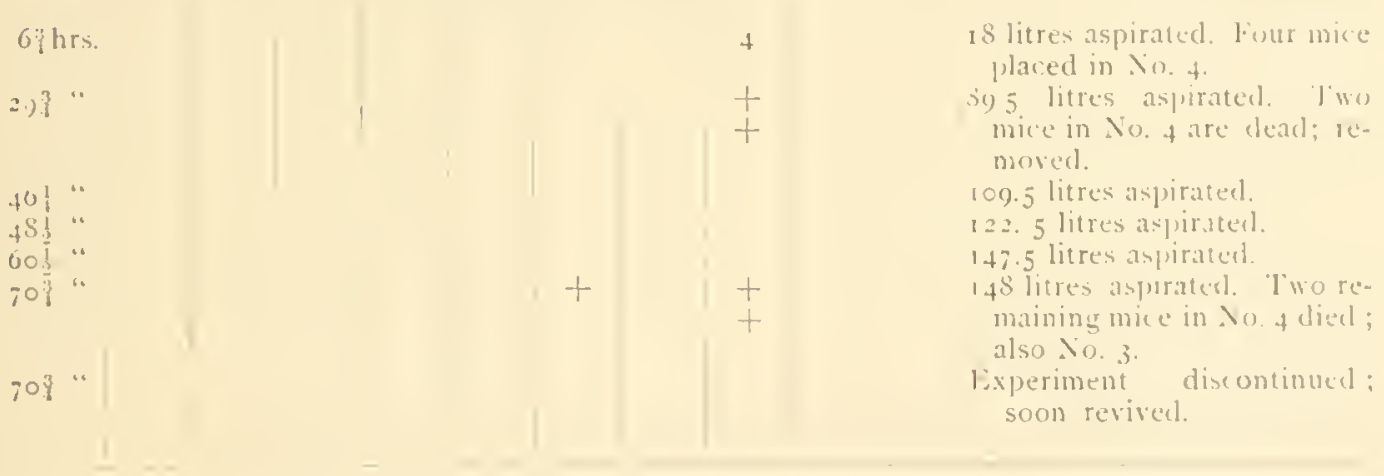

Continued as Experiment 24, after interval of two days. May 16, 1804.

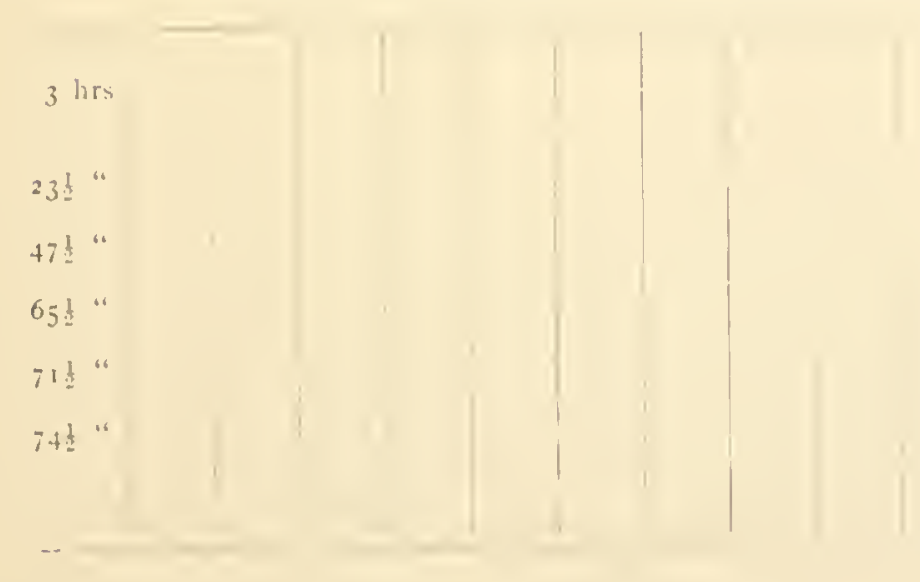

Fesh mice in Nos. 3 and 4. 22.5 litres aspirated. current cuntinued.

121.5 litres aspirated. All lively:

211.5 litres aspirated. All more or less oppressed.

276 litres aspirated. All more or less oppressed.

325 litres aspirated. All more or less oppressed.

$3+1$ 1.5 litres aspirated. Considerably eppressed; experiment stopined. 
Continued as Experiment 25, after interval of two day's. May 21, 1894.

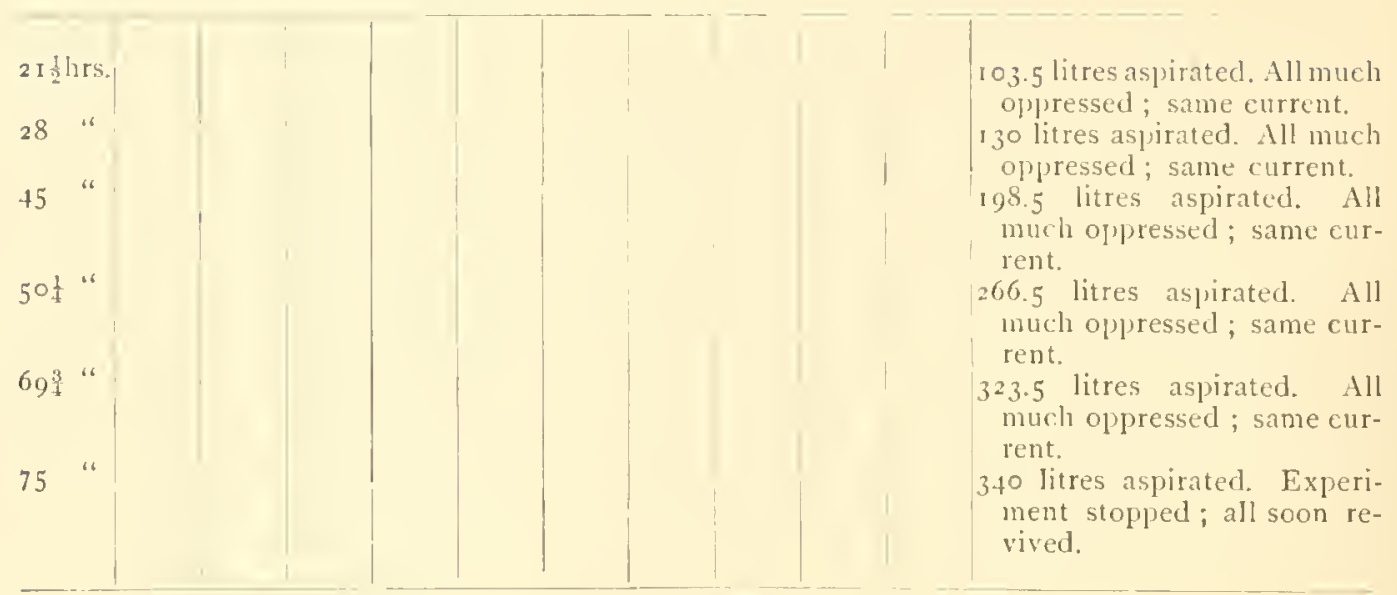

Continued as Experiment 26, after interval of one day. May 25, 1894.

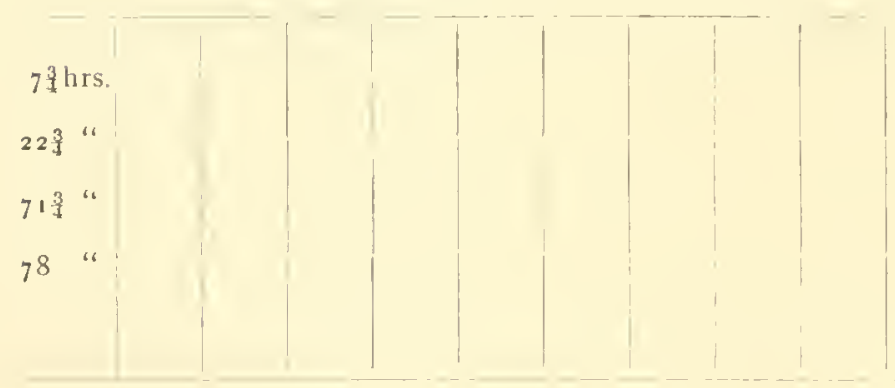

4-5 litres aspirated. All depressed ; current increased. 147 litres aspirated. All depressed; same current.

392.5 litres aspirated. Sunday between.

39.4.5 litres aspirated. Experiment stopped; all soon rerived.

Continued as Experiment 27 , after interval of one day. May 29, 1894 .

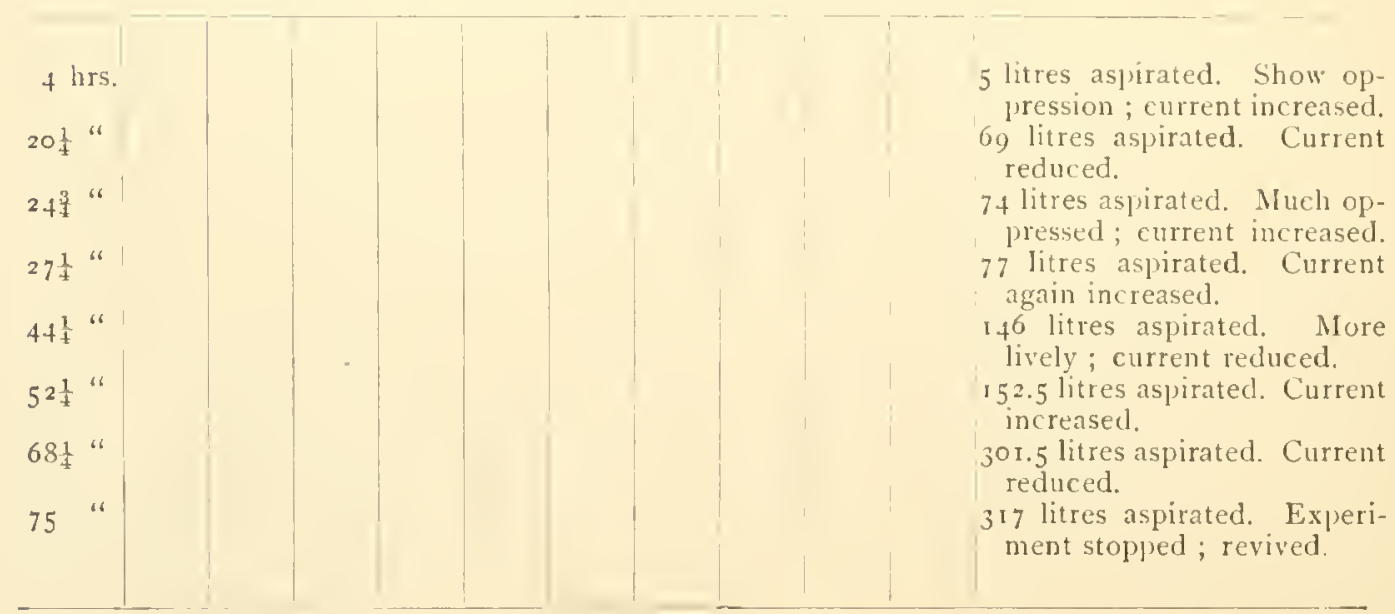


Continued as lixperiment $2 S$, alter interval of one day. June $2,1 S 94$

4 ihrs.
213 "
$45 “$
5210
683 ".
75 "

a No. $\mathrm{t}$ of Fxperiment $\mathbf{I} \mathrm{z}$ placed in $\mathrm{N} n .5 ;$ died in onc-half minute.

b XNo. 3 of lixperiment 11) placed in No. 4 ; died in three minutes.

c No. 2 of Experiment 17 placed in No. 5 ; died in one minute.
7 litres aspirated. Cirrent increased.

I.3. 4 litres asplirated Sime current.

227.5 litres asp irated. Curreme reduccel.

258 litres aspirated. Same current contimued.

30) 5 litres aspirated. (urrent again redured.

$43+$ lites aspirated. Experiment stopleel : revived.

No. 29. RROWN-SFQuard Fxprarient.

Commenced at 5.15 P.M.. June 5,1894 . Nice in 7 -litre bell jars. 5 in series.

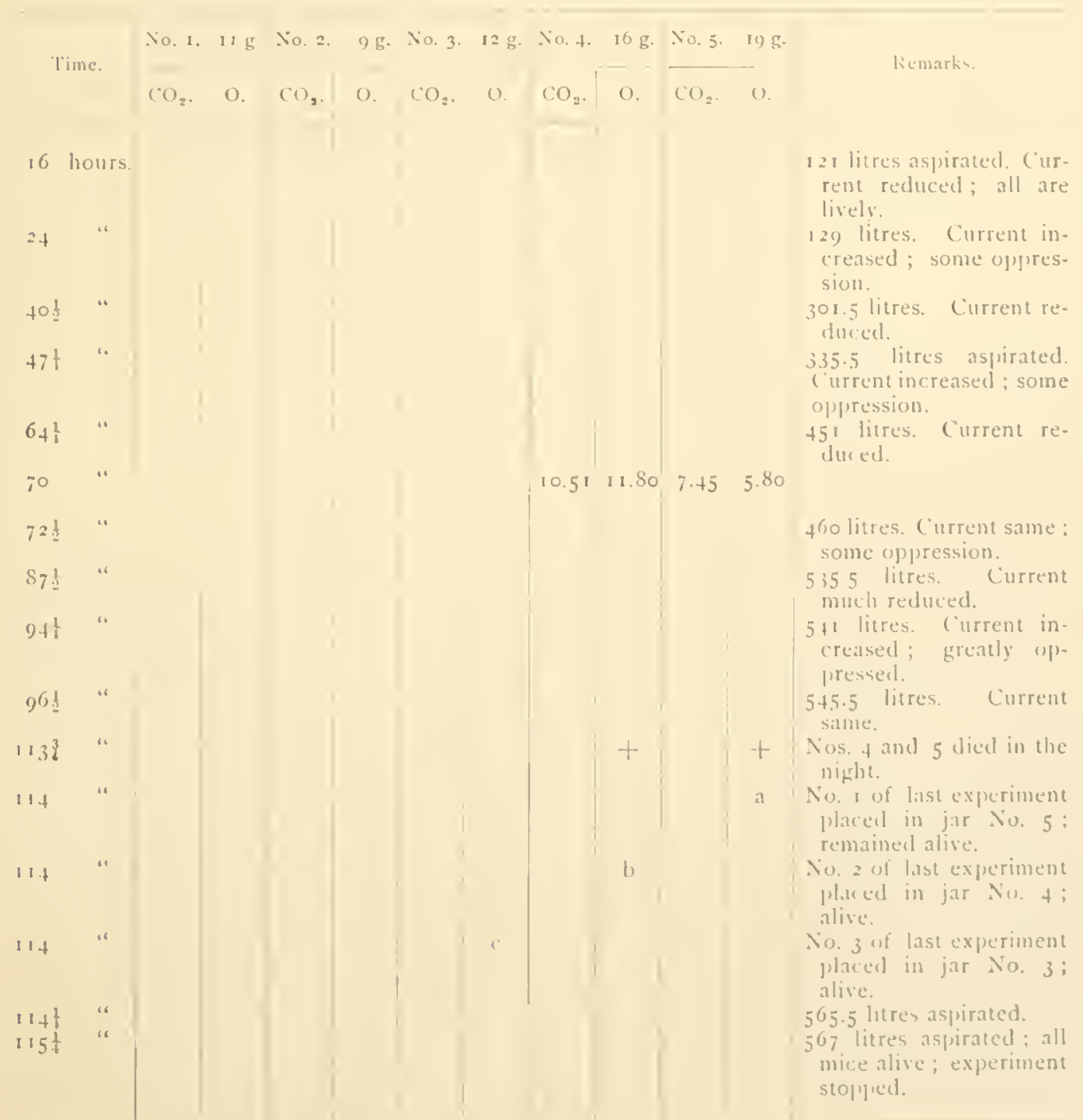


No. 30. JRown-Sequard Experiment.

Commenced at r. I 5 1.M., June 13,1894 . Guinea-pigs in 7 -litre bell jars. 5 in series.

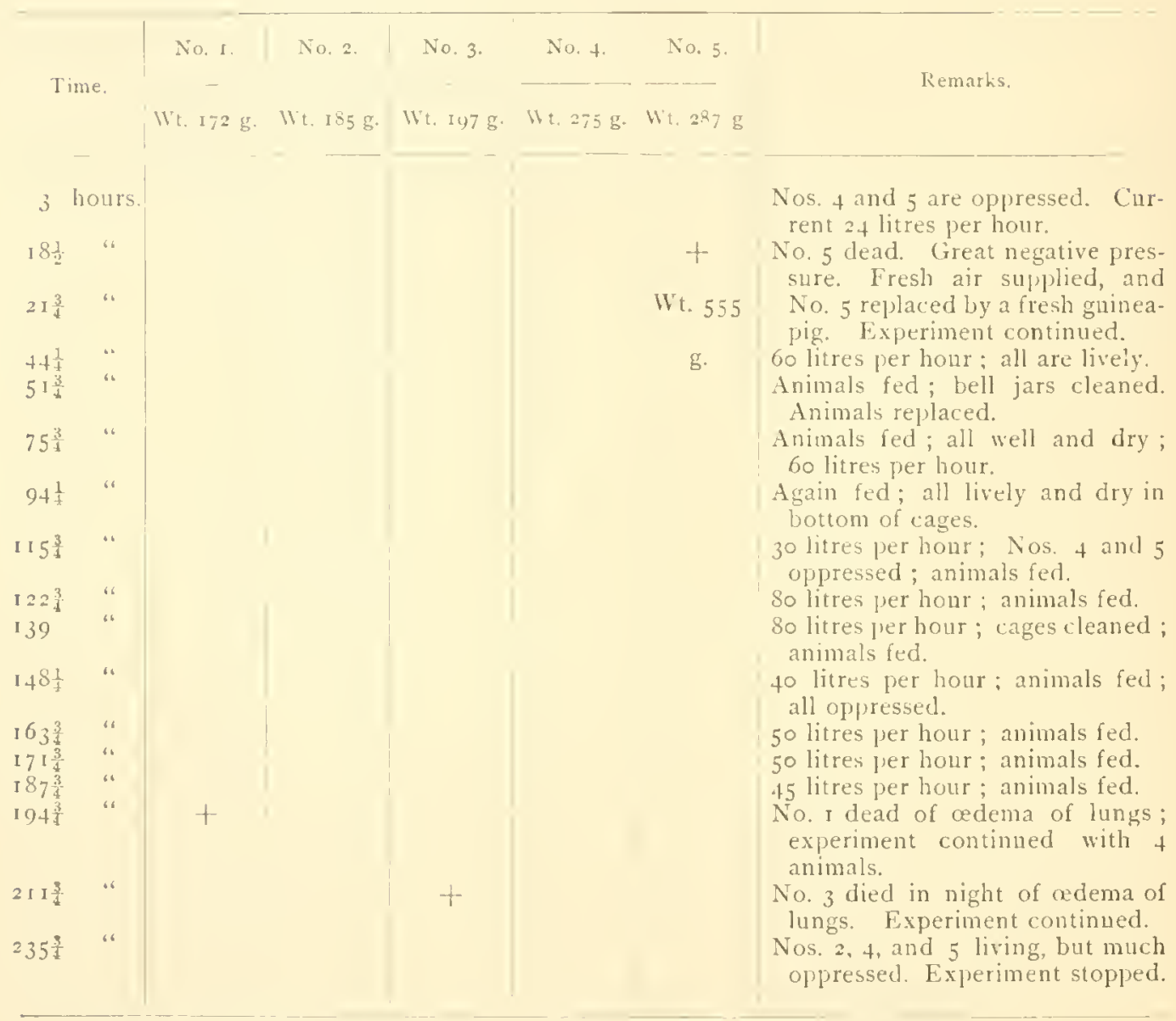

Experiment Iastel 9 days and 20 hours. No. 5 diet three days after close of experiment. No autopsy. 
No. 31. BROWX-SÉCLARD EXIPl RIMEXI.

Commenced at 5.15 P.31. June 25. 189. Rabbits in 37-litre bell jars 5 in sertes

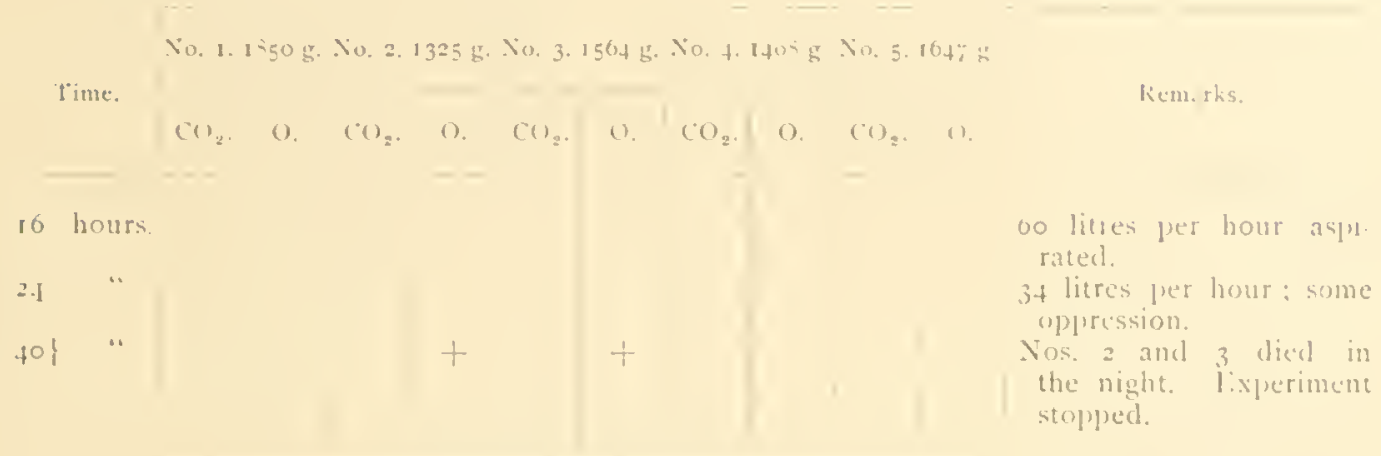

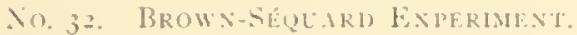

Commeneed at 10.15 A.M., 1)ecember 4. $189+$. Rabbits in 37 -litre bell jars. 6 in serus.

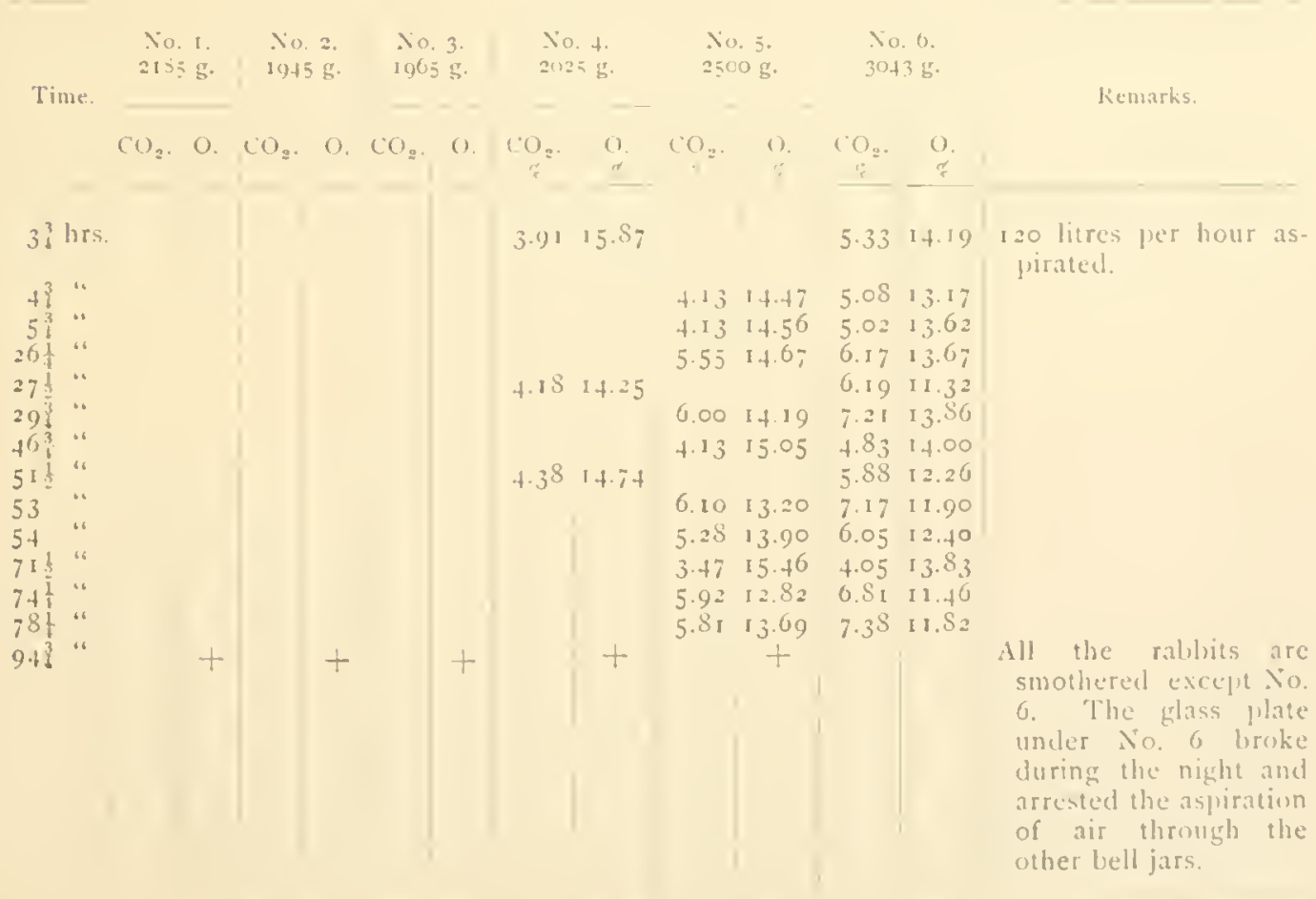


N1). 33. BROWN-SEgUARD HXPERIMENT.

Comnencel at 2.45 P.M., December 8, 1894 . Rabbits in 37 -litre bell jars. 6 in series.

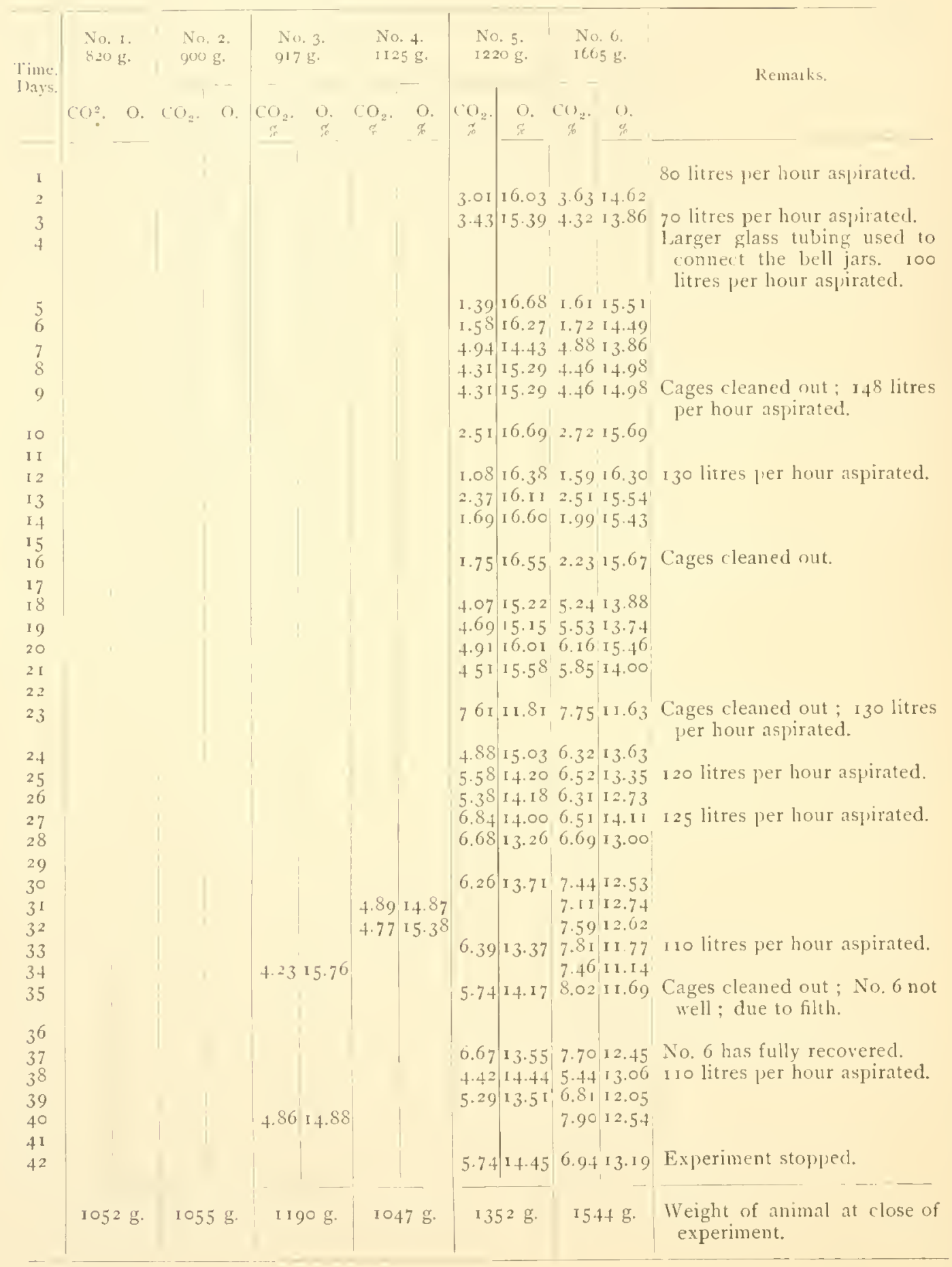




\section{NDEX.}

Mbbott, . . C................... 41 Abbett's modification of Hammond apparatus t6 . Ibsorption tubes................ 57 Air, expired, micro-organisms in....... 13.33 organic matter in. $4,5,8,11,14.34$ . oxidizable matter in............. Ammonia in conlensed moisture from ex-

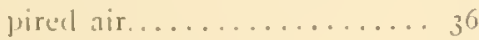
in air.................. 16

Animals, individual susceptibility of ...... 22 Apparatus for condensing moisture.....35, $3^{8}$ Appendix...................... 3.3

Asphrvia, composition of air proclucing.... 17 pathology of.............. 23

Atmospheres, artificial............ 50

Bacteria in hospital air.............. to

Bergey"s experiments.............. 13.33

Bernard, $(\ldots \ldots \ldots \ldots \ldots \ldots \ldots \ldots \ldots \ldots$

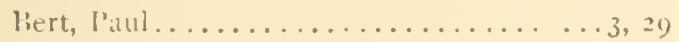

Beu, J................... 11, 15. 31

bibliography...................... 29

lilack Iloke of Calcutta............. 2

Blood-counts. . . . . . . . . . . . . . 59

brown-Scipuard apparatus............ 56 " and d'drsonval ......5, 7, 13 " experiments.........60

liunte's gas burette................ 4

Carbonic acid, efferts of........2, $4,17,47$ Conclusions..................... 34

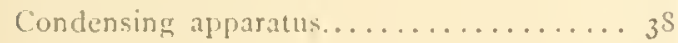

Consumption, causes of............ 26

Drstre and toge..............6, 30

Dust filter.................. 16, 39

Fasting, effects of, on expired air........ 15 Friedländer and Herter......... 19, 29, 31

Gaseous mixtures............... 18

IIabit, effects of .............. I9, 25 HaIdanc and Smith.............. 11, 30 Hammond, $11 . .1 \ldots \ldots \ldots \ldots \ldots \ldots . . \ldots 1,29$ " experiments...........

Ilermans, J. T. 1.................. 29

IIospital ward, air of............. 39
Injections of lipund condensed from exhaled air............. $\ldots, 8,10,20,5.3$

I. eblanc's researches............. 2 I.ehmann and Jessen. ............8, 15, 30 lijuri and Crisafulli.................. 30 l.ülobert and lecters.............. 12, jt

Margonty, J. M. F...............9, 30 Merkel, Micro-organisms in expired air. . . . . . 3.3 .3 Moisture of exhaled air...........5. 15. 34 Mouth, cleansing of, effects of .........37 decomposing organic matters in.... I5

Negative pressure................ 58

Oelors, cause of.................26 Olmatcel, 1)r. Ing:rsoll.............. 1 Organic matter in human breath......... 37 Oxigen, diminution of, elferts of ...... 18

Pettenkofer, M.................. 29

l'ulmonary liquid, injection of......... 6

Ransome, $1 \ldots \ldots \ldots \ldots \ldots \ldots \ldots \ldots \ldots$. 15, 29

Ramer.................... . 12.32

Regnault and keiset................. 29 Renk, $F^{\prime} \ldots \ldots \ldots \ldots \ldots \ldots \ldots \ldots \ldots \ldots$. . . . . . . 31 Richardson, 13. W..............3. 19. 29 Richarelson's experiment. . . . . . . . . fo fo Rusio-Giliberti and Alessi.......... 70

Sanfelice, $1 . \ldots \ldots \ldots \ldots \ldots \ldots \ldots \ldots \ldots \ldots . \ldots \ldots$. 31 Secgen and Nowak.............. 5, 29 smith, R. A.................. 29

'Temperature, effects of.............. 25

Toleration of foul air, actuired......... I9

Uffelmann, J.......................

Valentin, G........................ 29

Ventilation, insutficient, elferts of.......2, 60

Von llofmann-itellenhof... ......... \&

Warwick, Dr. Hill $5 . . \ldots \ldots \ldots \ldots \ldots \ldots$....

Weight of animals, cllect of loredthing exjured

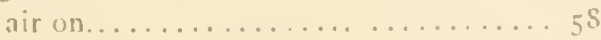

$\|$ iirtz, R................. 





COLUMBIA UNIVERSITY LIBRARY

'ilhis buotis is cuc on the chate inlicatrd below, or at the expiration of a definite period after the date of borrowing, as provided hy the rules of the Library or by special arrangement with the Librarian in charge.

\begin{tabular}{|c|c|c|c|}
\hline DATE GOPROWED & DATE DUE & DATE EORRDWED & DATE DUE \\
\hline & & & \\
\hline & & & \\
\hline & & & \\
\hline & & & \\
\hline - & & & \\
\hline$x^{2}=-1-$ & & & \\
\hline & & & \\
\hline & & & \\
\hline & & & \\
\hline & & & \\
\hline & & & \\
\hline & & & \\
\hline & & & \\
\hline & & & \\
\hline & & & \\
\hline C281238)M 100 & & & \\
\hline
\end{tabular}




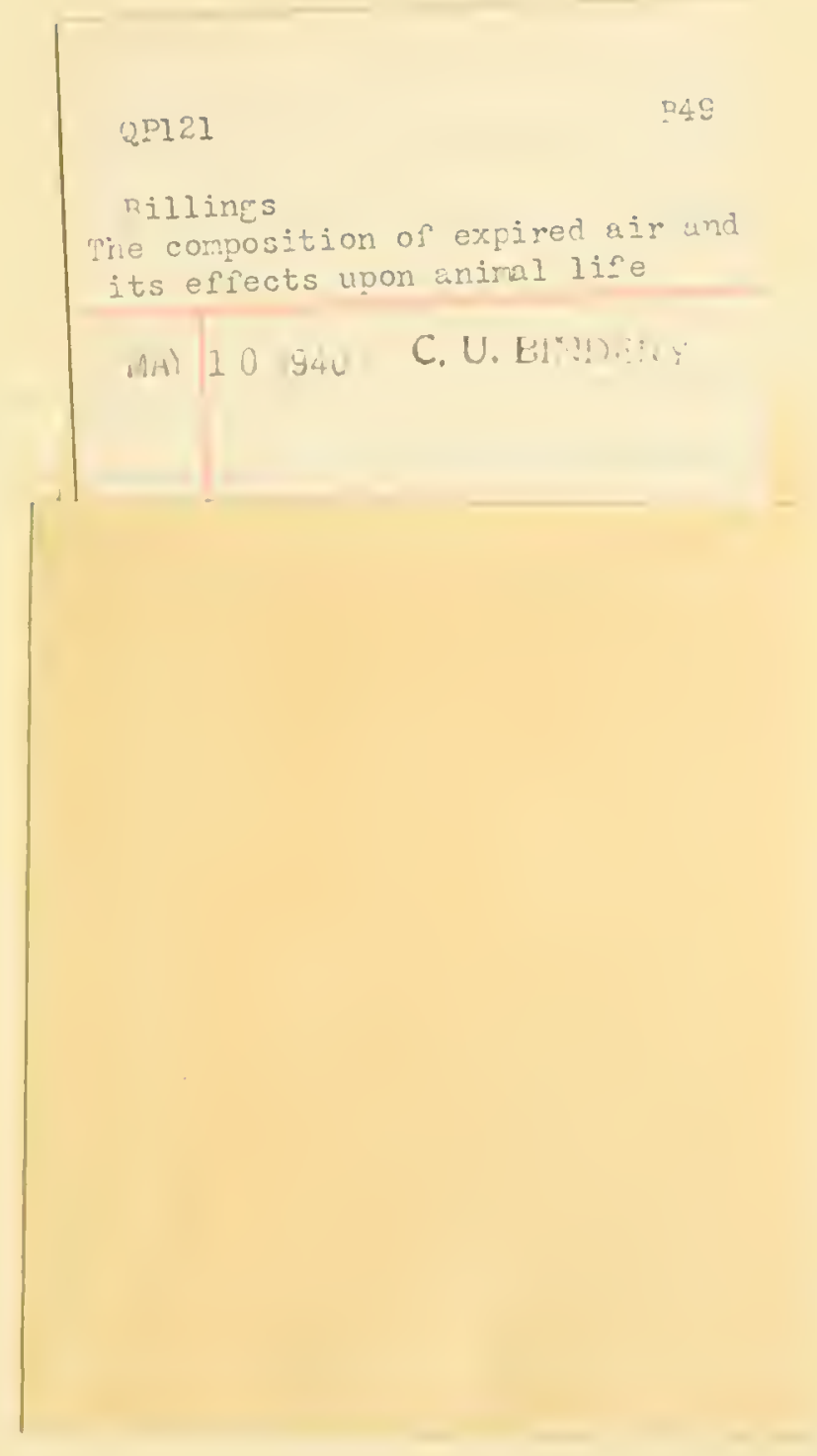


